\title{
TATIANA TANAKA
}

Diagnóstico etiológico das endoftalmites e análise direta do humor vítreo em frasco de hemocultura por espectrometria de massas MALDI-TOF

\author{
Tese apresentada à Faculdade de Medicina da \\ Universidade de São Paulo para obtenção do título \\ de Doutor em Ciências \\ Programa de Oftalmologia \\ Orientadora: Dra. Joyce Hisae Yamamoto
}

(Versão corrigida. Resolução CoPGr 6018/11, de 13 de outubro de 2011.

A versão original está disponível na Biblioteca da FMUSP)

\section{São Paulo}




\section{Dados Internacionais de Catalogação na Publicação (CIP)}

Preparada pela Biblioteca da

Faculdade de Medicina da Universidade de São Paulo

Creprodução autorizada pelo autor

Tanaka, Tatiana

Diagnóstico etiológico das endoftalmites e análise

direta do humor vítreo em frasco de hemocultura por

espectrometria de massas MALDI-TOF / Tatiana

Tanaka. -- São Paulo, 2019.

Tese (doutorado)--Faculdade de Medicina da

Universidade de São Paulo.

Programa de Oftalmologia.

Orientadora: Joyce Hisae Yamamoto.

Descritores: 1.Endoftalmite 2.Corpo vítreo

3. Microbiologia 4.Espectrometria de massas por

ionização e dessorção a laser assistida por matriz

5. Infecções bacterianas 6.Prognóstico

USP / FM/DBD-165/19

Responsável: Erinalva da Conceição Batista, CRB-8 6755 


\section{Dedicatória}

Dedico essa tese aos meus pais.

A união da nossa família e os valores de vida que tenho devem-se a eles, que são minha fonte de inspiração e orgulho. Todas as minhas conquistas dedico eternamente a essas duas pessoas.

Ao meu pai, Helio Tanaka, que sempre me transmitiu o exemplo de força, empreendedorismo, otimismo, caráter e disposição a sempre ajudar às pessoas.

A minha mãe, Marília Missae Tsunouchi Tanaka, meu exemplo de garra, perfeccionismo, e amor incondicional aos filhos.

Grande parte do meu incentivo para concretizar essa tese, veio do apoio dela que me norteou. Sem dúvida, meu maior exemplo de mulher que tanto admiro e me espelho.

Dedico também,

Aos meus irmãos, Adriano Tanaka e Leandro Tanaka, por todo apoio e estarem presentes em todas as etapas da minha vida.

A minha sobrinha, Isabella Sardinha Tanaka, que veio alegrar e unir ainda mais a família. 


\section{Agradecimentos}

A minha orientadora, Dra. Joyce Hisae Yamamoto, pela impecável orientação desta tese e, por permitir conviver e aprender com a pessoa excepcional que é; por me mostrar os caminhos difíceis que envolvem a pesquisa e importância da persistência. Modelo de ética, disciplina e dedicação.

Ao Dr. João Nobrega de Almeida Junior, eterna gratidão por todo auxílio na realização desse projeto e acreditar na parceria com a Oftalmologia; pessoa ímpar que tenho grande admiração pela sua dedicação à pesquisa.

Ao Prof. Dr. Remo Susanna Junior, pelo exemplo de liderança, apoio e incentivo à pesquisa dentro do Departamento de Oftalmologia e a esse projeto.

Ao Prof. Dr. Hisashi Suzuki e ao Prof. Dr. Walter Yukihiko Takahashi, minhas inspirações tanto como professores quanto oftalmologistas especialistas de retina.

Ao Dr. Yoshitaka Nakashima pela amizade, pelos ensinamentos acadêmicos, pelos ensinamentos de vida e por compartilhar do mesmo grande amor pela Casa de Arnaldo.

Ao Dr. Armando Shioji Tanaka, pelo carinho fraterno de tio e pelo exemplo de profissional oftalmologista e de pessoa com integridade ímpar de caráter.

A Dra. Luiza Manhezi Shin de Oliveira, ao Dr. Bruno Fortaleza de Aquino Ferreira, a Dra. Thaisa Silveira Barbosa, ao Dr. Eduardo Ferracioli Oda e a Dra. Juliana Mika Kato, por auxiliarem na coleta e orientação aos residentes e, principalmente, por ajudar a criar uma nova cultura dentro do HCFMUSP e mostrarem a importância desse trabalho.

A todos os Professores, assistentes, colegas, residentes e funcionários do Departamento de Oftalmologia do Hospital das Clínicas da Faculdade de Medicina da Universidade de São Paulo pelo incentivo, ensinamentos, exemplos e apoio. 
Ao Prof. Dr. Alberto José da Silva Duarte, Dra. Leila Antonangelo e Dra. Flavia Rossi, da Divisão de Laboratório Central, por permitirem desenvolver esse trabalho em conjunto e melhorar o diagnóstico laboratorial em várias doenças da Oftalmologia no HCFMUSP.

A toda equipe do Laboratório de Microbiologia, em especial a Valeria Teixeira Alves Rosa e a Rosilaine Souza Arruda Teberges, pessoas ímpares que colaboraram na coleta de dados laboratoriais dos pacientes e, mesmo diante do caos da rotina, sempre estavam dispostas a ajudar e ensinar; e a Karoline de Lemes G Correa, pela ajuda na realização das análises laboratoriais.

A toda equipe do Laboratório de Biologia Molecular, em especial ao Dr João Renato Rebello Pinho, ao Dr. Andre Mario Doi, a Dra. Raquel Girardello, a Luciane de Carvalho Sarahyba e a Lia Mara Barreira, que sempre nos apoiaram para desenvolvermos nossos projetos para PCR.

Aos meus tios Alice Keiko Tsunouchi Whatley Dias e Alvaro Whatley Dias Neto, por todo apoio e carinho.

A todos meus amigos por todo incentivo, apoio, ouvido e carinho.

A Regina Ferreira de Almeida, por sempre ajudar a todos os alunos da pósgraduação, com carinho e dedicação.

A Coordenação de Aperfeicoamento de Pessoal de Nível Superior (CAPES), pelo suporte financeiro por meio da bolsa de doutorado.

A todos colegas e amigos oftalmologistas que buscam o melhor aos seus pacientes e entraram em contato comigo para orientação em relação a coleta do material e envio, mesmo sendo final de semana ou véspera de feriado, possibilitando que esse projeto fosse implementado. 
O sucesso nasce do querer, da determinação e persistência em se chegar a um objetivo.

Mesmo não atingindo o alvo, quem busca e vence obstáculos, no mínimo fará coisas admiráveis.

José de Alencar 


\section{Normalização adotada}

Esta tese está de acordo com as seguintes normas, em vigor no momento desta publicação:

Referências: adaptado de International Commitee of Medical Journals Editors (Vancouver)

Universidade de São Paulo. Faculdade de Medicina. Divisão de Biblioteca e Documentação. Guia de apresentação de dissertações, teses e monografias. Elaborado por Anneliese Carneiro da Cunha, Maria Julia de A. L. Freddi, Mara F. Crestana, Marinalva de Souza Aragão, Suely Campos Cardoso, Valéria Vilhena, $3^{\text {a }}$ ed. São Paulo: Divisão de Biblioteca e Documentação; 2011.

Abreviaturas dos títulos dos periódicos de acordo com List of Journals Indexed in Index Medicus. 
Sumário 


\section{SUMÁRIO}

Lista de abreviaturas, símbolos e siglas

Lista de Figuras

Lista de Tabelas

Resumo

Summary



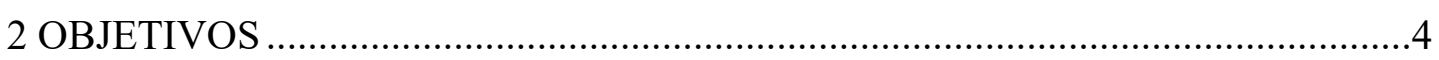

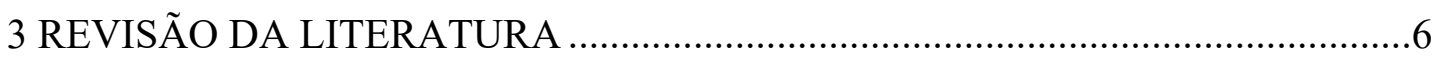

3.1 Incidência das endoftalmites ............................................................... 7

3.2 Fatores de risco para endoftalmite aguda pós-cirurgia de catarata................ 9

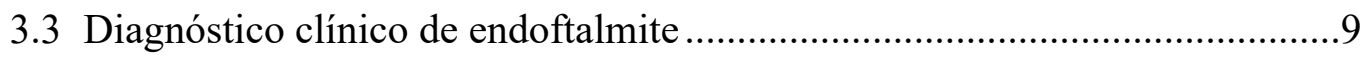

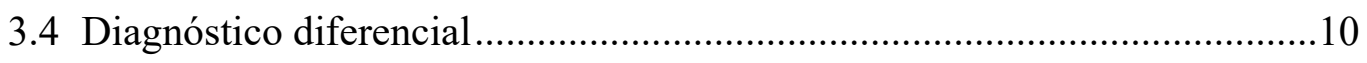

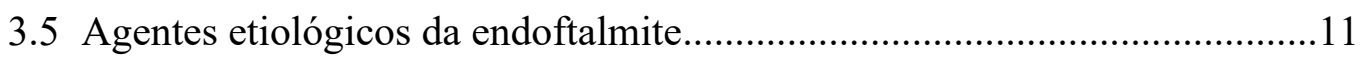

3.6 Métodos para identificação do agente etiológico ........................................12

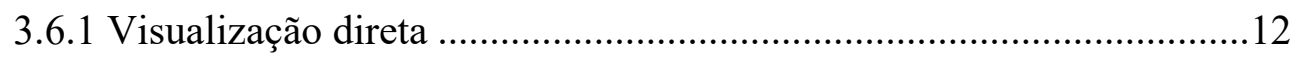

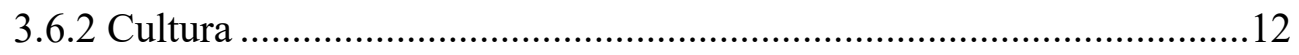

3.6.3 Espectrometria de massas MALDI-TOF ..........................................18

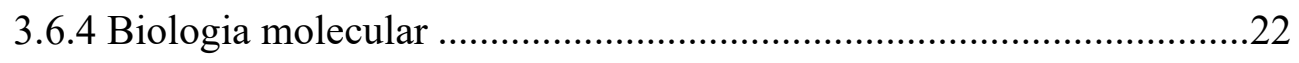

3.7 Diagnóstico etiológico de endoftalmite no Brasil ......................................23

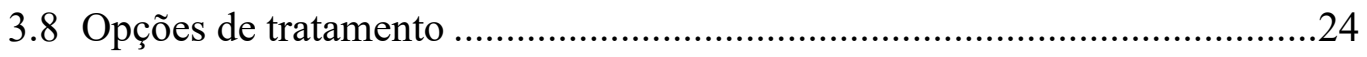

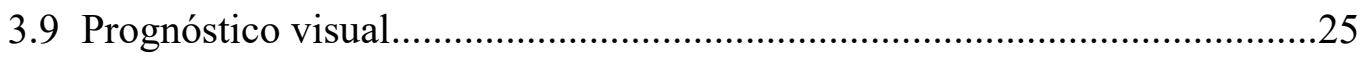

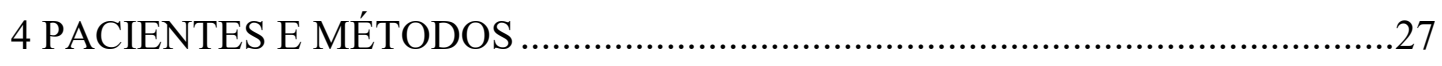

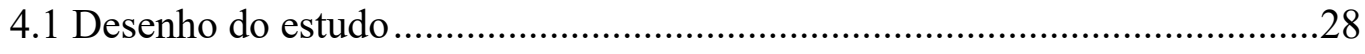

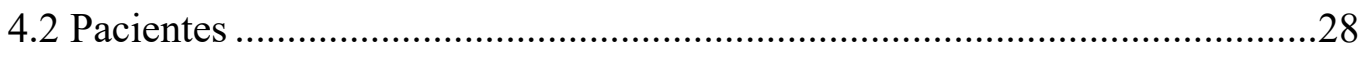

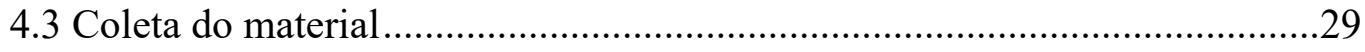

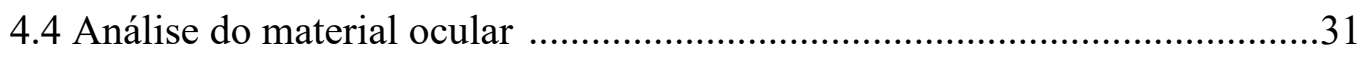



4.4.2 Espectrometria de massas MALDI-TOF direto...................................32

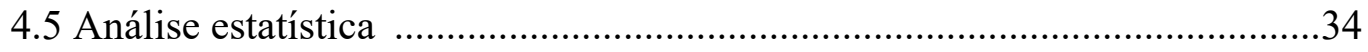

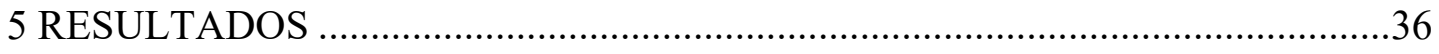


5.1 Aplicação da análise direta do humor vítreo em frasco de hemocultura pela EM MALDI-TOF no diagnóstico das endoftalmites ...........................40

5.2 Análise dos aspectos clínicos dos casos com endoftalmite .........................49

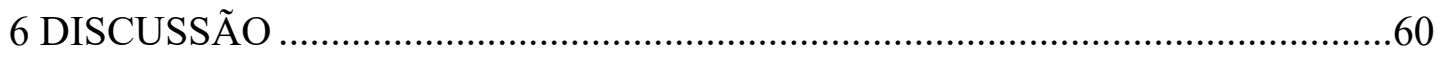

6.1 Métodos para identificação do agente etiológico .......................................61

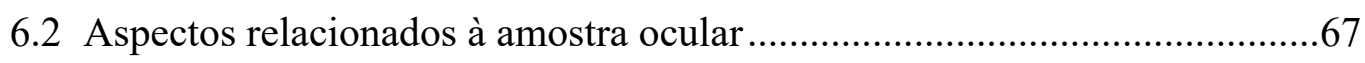

6.3 Aspectos relacionados à fonte de infecção ................................................69

6.4 Aspectos relacionados ao espectro microbiano e sua relevância clínica.......73

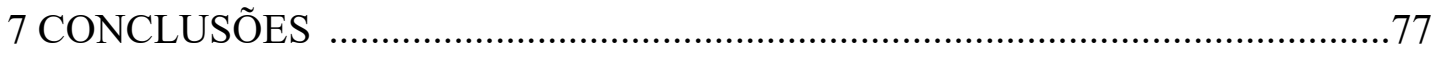

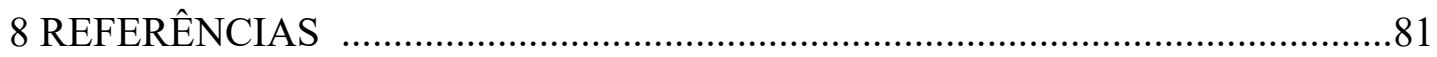



9.1 Aprovação pelo Comitê de Ética Institucional ............................................105

9.2 Termo de Consentimento Livre e Esclarecido............................................108

9.3 Publicação: Diagnostic Microbiology and Infection Disease 2017 ............112

9.4 Publicação : Clinics 2019 ...........................................................................115 
Listas 


\section{ABREVIATURAS, SÍMBOLOS E SIGLAS}

ANVISA

ATS

AV

$\mathrm{C}$

CDC

CD

CLSI

DLC

DNA

E. cloacae

E. faecalis

e.g.

EM

EMs

Et al.

Etc

EUA

ESCRS

EVS

FDA

Fig.

FMUSP

G

$\mathrm{h}$

H. influenzae

HA

HCFMUSP

HIV

HPLC
Agência Nacional de Vigilância Sanitária

Antibiotic test sensitivity

acuidade visual

catarata

Centers for Disease Control and Prevention

conta dedos

Clinical and Laboratory Standards Institute

Divisão de Laboratório Central do Hospital das Clínicas da Faculdade de Medicina da Universidade de São Paulo

ácido desoxirribonucleico

Enterobacteria cloacae

Enterococco faecalis

por exemplo (exempli gratia)

espectrometria de massas

espectro de massas

e outros (et alii)

e outros (et cetera)

Estados Unidos da América

European Society of Cataract \& Refractive Surgeons

Endophthalmitis Vitrectomy Study

Food and Drug Administration

Figura

Faculdade de Medicina da Universidade de São Paulo

glaucoma

horas

Haemophilus influenzae

humor aquoso

Hospital das Clínicas da Faculdade de Medicina da Universidade de São Paulo

human immunodeficiency virus

high performance liquid chromatography 


\begin{tabular}{|c|c|}
\hline HV & humor vítreo \\
\hline i.e. & isto é (id est) \\
\hline ID & identificação \\
\hline IIV & injeção intravítrea \\
\hline LIO & lente intraocular \\
\hline MALDI & matrix-assisted laser desorption/ionization \\
\hline $\mathrm{mg}$ & miligramas \\
\hline $\mathrm{mL}$ & mililitro \\
\hline MM & movimento de mãos \\
\hline MS & mass spectrometry \\
\hline NI & não informado \\
\hline NR & não realizado \\
\hline $\mathrm{p}$ & probabilidade de significância \\
\hline p. & página \\
\hline P. aeruginosa & Pseudomonas aeruginosa \\
\hline PCR & reação em cadeia da polimerase (polymerase chain reaction) \\
\hline PL & percepção luminosa \\
\hline PNA-FISH & peptide nucleic acid-fluorescence in situ hybridization \\
\hline $\mathrm{R} \$$ & reais \\
\hline $\mathrm{RDC}$ & Resolução da Diretoria Colegiada \\
\hline RNA & ácido ribonucleico \\
\hline rpm & rotação por minuto \\
\hline S. aureus & Staphylococcus aureus \\
\hline S. epidermidis & Staphylococcus epidermidis \\
\hline S. gordonii & Streptococcus gordonii \\
\hline S. haemolyticus & Staphylococcus haemolyticus \\
\hline S. lugdunensis & Staphylococcus lugdunensis \\
\hline S. marcencens & Serratia marcencens \\
\hline S. mitis & Streptococcus mitis \\
\hline S. pneumoniae & Streptococcus pneumoniae \\
\hline S. sanguinis & Streptococcus sanguinis \\
\hline S. saprophyticus & Staphylococcus saprophyticus \\
\hline SDS & sodium dodecyl sulphate \\
\hline$s p$ & espécie \\
\hline
\end{tabular}




$\begin{array}{ll}\text { SPL } & \text { sem percepção luminosa } \\ \text { spp } & \text { várias espécies } \\ \text { SUS } & \text { Sistema Único de Saúde } \\ \text { TASS } & \text { toxic anterior segment syndrome } \\ \text { TAT } & \text { tempo de identificação (turnaround time) } \\ \text { TSV } & \text { transconjunctival sutureless vitrectomy } \\ \text { TOF } & \text { time offlight } \\ \text { TSA } & \text { teste de sensibilidade ao antibiótico } \\ \text { USD } & \text { dólares } \\ \text { V. } & \text { volume } \\ \text { VGS } & \text { Streptococcus do grupo viridans } \\ v s & \text { contra (versus) } \\ \text { VVPP } & \text { vitrectomia via pars plana } \\ \mu L & \text { microlitro } \\ \mu \mathrm{m} & \text { micrometro }\end{array}$




\section{FIGURAS}

Figura 1 - Princípio da tecnologia de espectrometria de massas por ionização/ dessorção a laser assistida por matriz por tempo de voo (MALDI-TOF)

Figura 2 - Fluxograma da coleta e envio de material intraocular para análise nos casos suspeitos de endoftalmite

Figura 3 - Etapas seguidas pela cultura convencional e pela identificação direta pela espectrometria de massas MALDI-TOF. A linha em azul define o tempo para diagnóstico (turnaround time, TAT)

Figura 4 - Organograma com o número de casos com suspeita de endoftalmite exógena ou endógena incluídos e excluídos no estudo

Figura 5 - Box-and-Whiskers plot do tempo de identificação (em horas) para os patógenos identificados no humor vítreo de 37 pacientes (39 amostras) com endoftalmite, na cultura convencional e na análise direta pela EM MALDI-TOF $(p<0,001)$. Valores extremos (Outliers) foram marcados com asteriscos 


\section{TABELAS}

Tabela 1 - Fonte de infecção de endoftalmite e organismos causais mais frequentes

Tabela 2 - Meios de cultura e microrganismos isolados

Tabela 3 - Estudos comparando positividade da cultura convencional e do uso de frasco de hemocultura em casos de endoftalmite

Tabela 4 - Agentes etiológicos detectados na cultura de amostras de humor vítreo/ humor aquoso de 53 casos de endoftalmite

Tabela 5 - Culturas de amostras de humor vítreo de dois pacientes com endoftalmite com resultados polimicrobianos

Tabela 6 - Tempo de identificação (turnaround time, TAT) de Candida albicans pela cultura convencional e pela análise direta do humor vítreo inoculado em frasco de hemocultura infantil pela EM MALDI-TOF em amostras de 3 pacientes com suspeita de endoftalmite endógena

Tabela 7 - Identificação do patógeno bacteriano pela cultura convencional e pela análise direta pela EM MALDI-TOF com o tempo de identificação (turnaround time, TAT) em 61 amostras oculares de 47 pacientes com suspeita de endoftalmite

Tabela 8 - Tempo de identificação (turnaround time, TAT ID) pela cultura convencional e pela análise direta por EM MALDI-TOF, segundo cada patógeno, nas 39 amostras oculares, positivas em ambos os métodos, de 37 pacientes com suspeita de endoftalmite.

Tabela 9 - Positividade das culturas de 12 amostras, nas quais foram usadas filtro de membrana, de pacientes com suspeita de endoftalmite. 48 
Tabela 10 - Positividade na cultura e variáveis relativas à amostra ocular de pacientes com endoftalmite.

Tabela 11 - Positividade nas culturas de material ocular dos 87 pacientes com suspeita de endoftalmite de acordo com a fonte de infecção

Tabela 12 - Prognóstico visual de 48 pacientes com endoftalmite bacteriana confirmada pela análise do material intraocular (cultura convencional com ou sem EM MALDI-TOF direto) de acordo com o patógeno identificado

Tabela 13 - Características clínicas dos 34 pacientes com suspeita de endoftalmite e análise negativa na microbiologia

Tabela 14 - Susceptibilidade aos antibióticos dos patógenos isolados nas 44 amostras oculares com cultura positiva para bacterias Grampositiva ou Gram-negativa de pacientes com suspeita de endoftalmite. 
Resumo 
Tanaka T. Diagnóstico etiológico das endoftalmites e análise direta do humor vítreo em frasco de hemocultura por espectrometria de massas MALDI-TOF [tese]. São Paulo: Faculdade de Medicina, Universidade de São Paulo; 2019.

Introdução: As endoftalmites infecciosas apresentam prognóstico visual reservado, sendo essencial o diagnóstico rápido assegurando tratamento imediato. $\mathrm{O}$ diagnóstico etiológico precoce pode ser importante para adequação do antibiótico e definir a melhor conduta. A cultura de amostra de humor vítreo para isolamento e identificação do agente etiológico apresenta como principal desvantagem o tempo necessário de alguns dias para um resultado definitivo. Desta forma, a busca por técnicas que proporcionem a identificação rápida e precisa se faz necessária. Objetivos: avaliar a análise direta do humor vítreo, inoculado em frasco de hemocultura infantil, de pacientes com endoftalmite infecciosa utilizando a espectrometria de massas (EM) por ionização e dessorção a laser assistida por matriz por tempo de voo (matrix-assisted laser desorption/ionization, MALDI-TOF); comparar os resultados obtidos com o método convencional de cultura; analisar as características clínicas de acordo com os agentes etiológicos detectados; analisar os fatores que podem influenciar a positividade na identificação do agente etiológico. Métodos: estudo prospectivo, observacional com análise de amostras de humor vítreo, não diluído e diluído, de 96 pacientes com suspeita de endoftalmite infecciosa (critério de inclusão) diagnosticados no período entre outubro de 2015 e junho de 2017. O material foi inoculado em frasco de hemocultura e analisado pela cultura convencional e pela análise direta do humor vítreo pela EM MALDI-TOF. O tempo de identificação (turnaround time, TAT) pelos dois métodos foi comparado (teste de Wilcoxon pareado). Prognóstico visual após 3 meses do diagnóstico foi avaliado conforme o agente identificado. As variáveis avaliadas quanto à amostra foram: uso de antibiótico intravítreo prévio, amostra diluída ou não, obtida por biópsia vitrea ou por vitrectomia via pars plana e obtida do $1^{\circ}$ ou $2^{\circ}$ procedimento. Resultados: Dos 96 pacientes avaliados, foram excluídos dois casos por contaminação da amostra e sete casos por não preencherem os critérios de inclusão. Dentre os 87 pacientes incluídos, a cultura foi positiva em $60,9 \%$ (53 pacientes), sendo isoladas bactérias Gram-positivas em 46 casos $(86,7 \%)$ e bactérias Gram-negativas em seis casos $(11,3 \%)$; dois casos com cultura polimicrobiana. Não foi identificada nenhuma bactéria anaeróbia. Em três casos foram identificados Candida albicans. A mediana do TAT do agente etiológico foi 50,6 horas (variação entre 18,5 e 187,50 horas) e de 15 horas (variação entre 3,1 e 94,0 horas) pela cultura convencional e com EM MALDI-TOF, respectivamente $(p<0,001)$. A concordância da análise direta do frasco de hemocultura infantil com EM MALDI-TOF em relação à cultura convencional foi $81,1 \%$, sendo $80,4 \%$ para bactérias Gram-positivas e $100 \%$ para bactérias Gram-negativas. Não houve significância na análise dos fatores que podem interferir nos resultados: uso de antibiótico ou não (positividade de $42,8 \% \mathrm{vs}$ $64,3 \%, \mathrm{p}=0,131$ ); amostra de humor vítreo diluído ou não (TAT de 18,05 horas $v s$ 17,03 horas, $\mathrm{p}=0,126$ ); biópsia vítrea em relação à vitrectomia (positividade 93,1\% vs $100 \%, \mathrm{p}=0,531)$. Os agentes mais prevalentes foram Staphylococcus epidermidis $(\mathrm{n}=15 ; 28,3 \%)$, Streptococcus pneumoniae $(\mathrm{n}=9 ; 17 \%)$ e Staphylococcus aureus $(\mathrm{n}=6$; $11,3 \%$ ). Dentre os casos por Staphylococcus epidermidis, $60 \%$ e 86,7\% apresentaram, no $3^{\circ}$ mês pós-tratamento, acuidade visual melhor ou igual que 20/60 e 20/200, respectivamente. Nos demais casos, apenas $12,1 \%$ tiveram acuidade visual melhor ou igual a 20/200. Observou-se resistência a ciprofloxacino (93\% a 100\%), moxifloxacino $(93 \%$ a $100 \%)$ e oxacilina $(50 \%$ a $79 \%)$ pelos Staphylococcus 
epidermidis e Staphylococcus haemolyticus. Conclusão: O presente estudo aplicou a análise direta pela EM MALDI-TOF em amostras de humor vítreo inoculadas em frasco de hemocultura e demonstrou uma redução mediana de $67,6 \%$ no tempo para identificação do agente etiológico em relação ao método de cultura convencional. Este método mostrou-se viável na rotina de um laboratório de microbiologia. Observou-se que os casos de endoftalmite por Staphylococcus epidermidis apresentaram melhor prognóstico visual em relação aos outros agentes. Possíveis fatores que possam interferir na positividade das análises não foram significativos.

Descritores: Endoftalmite; Corpo vítreo; Microbiologia; Espectrometria de massas por ionização e dessorção a laser assistida por matriz; Infecções bacterianas; Prognóstico. 
Abstract

ב 
Tanaka T. Etiological diagnosis of endophthalmitis by direct analysis of vitreous humor in blood culture bottle by MALDI-TOF mass spectrometry [thesis]. São Paulo: "Faculdade de Medicina, Universidade de São Paulo"; 2019.

Introduction: Infectious endophthalmitis presents a limited visual prognosis; rapid diagnosis is essential to assure prompt treatment. The early etiological diagnosis may be important to guide antibiotic therapy and to adjust treatment. The main disadvantage of using culture of vitreous humor for isolation and identification of the etiological agent is the required time of a few days for definitive results. Thus, the search for techniques that provide fast and accurate identification becomes necessary. Objectives: To evaluate direct analysis of vitreous humor in pediatric blood culture bottle of patients with infectious endophthalmitis using mass spectrometry (MS) with matrix-assisted laser desorption / ionization (MALDI-TOF); to compare the results obtained with the conventional culture method; to analyze the clinical characteristics according to the detected etiological agents; to analyze the factors that may influence positive identification of the etiologic agent. Methods: A prospective, observational study with undiluted and diluted vitreous humor samples of 96 patients with suspected infectious endophthalmitis (inclusion criterion), diagnosed from October 2015 to June 2017. The material was inoculated in a blood culture bottle and analyzed by conventional culture and by direct analysis of the vitreous humor by MALDI-TOF MS. The identification time (turnaround time, TAT) of the two methods was compared (Wilcoxon paired test). Visual prognosis three months after the diagnosis was assessed according to the identified agent. The variables evaluated in the sample were: the use of previous intravitreal antibiotics, diluted or not, obtained by vitreous biopsy or pars plana vitrectomy and obtained from the 1st or 2nd procedure. Results: Of the 96 patients evaluated, two cases were excluded due to contamination of the sample, while seven cases did not meet the inclusion criteria. Among the 87 patients that were included, the culture was positive in $60.9 \%$ (53 patients); Gram-positive bacteria were isolated in 46 cases $(86.7 \%)$ and Gram-negative bacteria in six cases $(11.3 \%)$; in two cases there was polymicrobial culture. No anaerobic bacteria were identified. In three cases Candida albicans were identified. The median TAT of the etiological agent was 50.6 hours (ranging from 18.5 to 187.50 hours), and 15 hours (ranging from 3.1 to 94.0 hours) in the conventional culture and with MALDI-TOF MS, respectively $(\mathrm{p}<0.001)$. The agreement of results from direct analysis with MALDI-TOF MS in relation to the conventional culture was $81.1 \%$, being $80.4 \%$ for Gram-positive bacteria and $100 \%$ for Gram-negative bacteria. There was no significance in the analysis of the factors that may interfere with the results: the use of antibiotic or not (positivity of $42.8 \% \mathrm{vs}$ $64.3 \%, \mathrm{p}=0.131$ ); diluted or non-diluted vitreous humor sample (TAT of 18.05 hours vs 17.03 hours, $p=0.126$ ); vitreous biopsy in relation to vitrectomy (positivity $93.1 \%$ vs $100 \%, \mathrm{p}=0.531)$. The most prevalent agents were Staphylococcus epidermidis (n $=15 ; 28.3 \%)$, Streptococcus pneumoniae $(\mathrm{n}=9 ; 17 \%)$ and Staphylococcus aureus $(\mathrm{n}$ $=6 ; 11.3 \%$ ). Among the cases due to Staphylococcus epidermidis, $60 \%$ and $86.7 \%$ showed visual acuity better than or equal to $20 / 60$ and 20/200, respectively, in the 3 rd month after treatment. In other cases, only $12.1 \%$ had visual acuity better than or equal to 20/200. Resistance to ciprofloxacin (93 to 100\%), moxifloxacin (93 to 100\%) and oxacillin (50 to $79 \%$ ) by Staphylococcus epidermidis and Staphylococcus haemolyticus was observed. Conclusion: The present study applied direct analysis by MALDI-TOF MS in vitreous humor samples inoculated in a blood culture bottle, and it showed a median reduction of $67.6 \%$ in time to identify the etiological agent in 
relation to the conventional culture method. This method proved to be feasible in the routine of a microbiology laboratory. It was observed that cases of endophthalmitis caused by Staphylococcus epidermidis had a better visual prognosis than other ones individually. Possible factors that could interfere in the positivity of the analyses were not significant.

Descriptors: Endophthalmitis; Vitreous body; Microbiology; Spectrometry, mass, matrix-assisted laser desorption-ionization; Bacterial infections; Prognosis. 
1 Introdução e Justificativa 


\section{INTRODUÇÃO E JUSTIFICATIVA}

As endoftalmites podem ser exógenas ou endógenas, sendo em ambas as situações uma complicação rara, porém, grave com importante comprometimento visual, na maioria das vezes, irreversível. As endoftalmites exógenas são observadas após cirurgia ocular ou trauma, e as endoftalmites endógenas ocorrem, geralmente, em situações de imunossupressão. A acuidade visual (AV) final maior ou igual a 20/400 varia de $22 \%$ a $67 \%$ dos casos, independente do tratamento ${ }^{(1-3)}$. Alguns patógenos, como Streptococcus e Enterococcus, denotam ser mais agressivos com 50\% a $80 \%$ dos casos com AV menor que 20/400 (2,3). Desta forma, a identificação precoce do agente etiológico é relevante permitindo um tratamento mais preciso, assim como permite a identificação de cepas resistentes aos principais antibióticos utilizados em Oftalmologia em nosso meio. Ademais, pode-se contribuir para o uso consciente dos antibióticos nas endoftalmites conforme o programa de gerenciamento para uso racional de antimicrobianos (antimicrobial stewardship programme) recentemente incorporado pelo Food and Drug Administration (FDA) dos Estados Unidos da América e está sendo implantado em alguns centros no Brasil (4). (https://www20.anvisa.gov.br/segurancadopaciente/index.php/publicacoes/item/prog rama-de-gerenciamento-para-o-uso-racional-de-antimicrobianos-antimicrobialstewardship) Outrossim, algumas situações clínicas com processo inflamatório intenso, e.g. síndrome tóxica do segmento anterior (toxic acute anterior segment syndrome, TASS), podem ser confundidas com endoftalmite infecciosa, e a utilização do melhor método de identificação pode permitir a realização do diagnóstico diferencial entre eles ${ }^{(5)}$.

Por conseguinte, pelos vários motivos apresentados inicialmente, a implantação da rotina para se identificar o agente etiológico nas endoftalmites se faz necessária em nosso meio. A otimização das etapas pré-analíticas e pós-analíticas das culturas podem auxiliar na escolha precoce de antibioticoterapia direcionada e melhorar o prognóstico visual dos pacientes com endoftalmite. Até início de 2012, em nosso Serviço Universitário, Hospital das Clínicas HCFMUSP, Faculdade de 
Medicina, Universidade de São Paulo, as infecções oculares e a definição do agente infeccioso causal não eram abordados com a atenção devida e o cenário era desalentador (coleta de material não padronizada, médicos em formação sem treinamento adequado, laboratórios da instituição independentes, etc.). Assim, foi necessário um esforço conjunto de médicos preceptores-residentes-assistentes e equipe de enfermagem em parceria com a Divisão de Laboratório Central, HCFMUSP e também com o Departamento de Moléstias Infecciosas e Parasitárias FMUSP, para que todo este processo de identificação de patógenos nas infecções oculares, incluindo as endoftalmites, fosse viável com competividade no cenário internacional.

Assim, o presente projeto é parte de um processo de implementação na identificação de patógenos nas infecções oculares. Nas endoftalmites infecciosas, o método convencional padrão-ouro de identificação do patógeno e avaliação do perfil de sensibilidade aos antimicrobianos é a cultura do material, sendo métodos por biologia molecular ainda uma análise complementar ${ }^{(6)}$. A sensibilidade da cultura para o diagnóstico etiológico nas endoftalmites varia entre $34 \%$ e $69 \%{ }^{(7,8)}$.

Em nosso meio e em várias partes do mundo, o manejo das endoftalmites pósoperatórias agudas foi fortemente influenciado pelo Endophthalmitis Vitrectomy Study (EVS) publicado em $1995^{\left({ }^{(8)}\right.}$. Neste importante e único estudo clínico randomizado de endoftalmite, a sensibilidade foi de $69 \%$ e o vítreo não diluído era colocado em placa de ágar chocolate, em caldo enriquecido de tioglicolato e em placa de ágar Sabouraud. Ainda no EVS, o material vítreo do cassete (material diluído) era analisado após uso de filtro estéril de membrana de acetato de celulose com poro de $0,45 \mu \mathrm{m}$; os pedaços do filtro eram semeados nos diferentes meios. Mas, é importante ressaltar que a análise de cultura realizada no EVS não é realidade na prática na maioria dos lugares, o que é demonstrado pela grande variação da sensibilidade da cultura na literatura em diferentes países ${ }^{(7-10)}$. Outra importante desvantagem da cultura no diagnóstico etiológico das endoftalmites é o tempo, que pode variar de dois a 60 dias para a identificação do agente ${ }^{(11)}$. Neste contexto, vários estudos, incluindo o estudo recente de nosso serviço, sugerem que o uso de frasco de hemocultura pediátrico para cultura do material ocular aumenta a sensibilidade na detecção do agente etiológico entre 52 e $71 \%{ }^{(12-14)}$. 
No intuito de diminuir o tempo de identificação do patógeno, mais recentemente, a espectrometria de massas (EM) por ionização e dessorção a laser assistida por matriz por tempo de voo (matrix-assisted laser desorption/ionization, MALDI-TOF), aplicada diretamente na amostra, vem sendo usada nos laboratórios de Microbiologia. Inicialmente, a espectrometria de massas foi usada, em 1975, para caracterizar extratos de bactéria de diferentes gêneros e espécies com fonte de ionização por impacto eletrônico. Na década de 1990, surgem os trabalhos que usam uma ionização branda, tal como o MALDI, provocando novo interesse na espectrometria de massas na identificação microbiana. Os equipamentos de EM possuem diversos analisadores que separam os íons de diferentes pesos/massas. Entre tais analisadores/separadores de íons, há aqueles que diferenciam os pesos/massas pelo tempo de voo destas moléculas em tubo de vácuo (time of flight, TOF). Desde final dos anos 1990, o sucesso desta técnica na rápida identificação de bactéria e fungos traduziu-se no aumento exponencial de publicações referentes à identificação de microrganismos com MALDI-TOF ${ }^{(15)}$.

A principal vantagem da EM MALDI-TOF sobre outras técnicas laboratoriais para identificação de microrganismos é a agilidade para obtenção dos resultados. $\mathrm{O}$ intervalo entre a confecção do depósito e a leitura final do isolado pode ser tão rápido como 30 a 60 minutos ${ }^{(16,17)}$. Os espectros de massas (EMs) são obtidos e processados por softwares específicos. A tecnologia de EM MALDI-TOF surge como uma nova ferramenta para os laboratórios de microbiologia e a identificação dos patógenos diretamente de hemoculturas pode diminuir o tempo de liberação dos resultados de forma significativa.

Desta forma, a proposta do presente estudo é aplicar este método EM MALDITOF no diagnóstico etiológico das endoftalmites. É importante ressaltar que, quando este estudo foi desenhado, não havia nenhum trabalho na literatura com proposta semelhante. 
2 Objetivos 
2 OBJETIVOS

\subsection{Objetivos primários}

2.1.1 Avaliar a tecnologia de análise direta do humor vítreo, inoculado em frasco de hemocultura, por espectrometria de massas MALDI-TOF no diagnóstico etiológico das endoftalmites bacterianas e fúngicas.

2.1.2 Comparar os resultados obtidos com a cultura convencional.

\subsection{Objetivos secundários}

2.2.1 Analisar as características clínicas dos casos de endoftalmite de acordo com os agentes etiológicos detectados.

2.2.2 Analisar os fatores que podem influenciar na positividade da identificação do agente etiológico. 


\section{Revisão da Literatura}




\section{REVISÃO DA LITERATURA}

O termo endoftalmite é usado para descrever infecções intraoculares causadas por bactéria ou fungo, envolvendo o humor vítreo e/ou humor aquoso. Entre $70 \% \mathrm{e}$ $81 \%$ das endoftalmites é exógena, ou seja, o inóculo infeccioso é externo tendo como principais fontes cirurgia ocular, injeção intravítrea ou trauma penetrante ocular ${ }^{(18,19)}$. As endoftalmites endógenas resultam de disseminação hematogênica do microrganismo durante uma bacteremia ou fungemia ${ }^{(20)}$.

\subsection{Incidência das endoftalmites}

A taxa de endoftalmite exógena difere entre os relatos em razão dos métodos de estudo, definição de endoftalmite, técnica cirúrgica, população de pacientes, influência ambiental e volume cirúrgico ${ }^{(21)}$. As endoftalmites pós-operatórias e póstrauma são as mais frequentes fontes de endoftalmite mundialmente, sendo $40 \%$ e $80 \%$ pós-operatórias e 2\% e $15 \%$ pós-trauma em inúmeros centros ao redor do mundo, incluindo o Brasil ${ }^{(22-28)}$. Diferenças regionais existem, por exemplo, endoftalmite póstrauma é observada entre $40 \%$ e $60 \%$ de todas as endoftalmites em alguns centros no Egito, India e China ${ }^{(25,29,30)}$. A incidência das endoftalmites pós-operatória de início agudo varia entre $0,0128 \%$ e $0,11 \%$ dos olhos submetidos à cirurgia intraocular, conforme a região do mundo ${ }^{(31,32)}$.

A incidência de endoftalmite após cirurgia de catarata vem variando nas últimas décadas ${ }^{(19,28,31,33)}$. Entre 1970 e 1990, houve uma redução gradual de 0,32\%, para $0,16 \%$ e para $0,08 \%$; no entanto, nos primeiros anos do século 21 houve um aumento para $0,26 \%$. Este aumento da taxa de endoftalmite foi associado às incisões clear cornea sem sutura com possível vazamento pela ferida, hipotonia no pósoperatório precoce e pela ausência de conjuntiva sobre a incisão corneana ${ }^{(34,35)}$. Nos anos subsequentes, mesmo sem mudanças significativas das técnicas cirúrgicas, a taxa 
de endoftalmite diminuiu significativamente ${ }^{(36-38)}$. As possíveis hipóteses para esta redução são mudanças da estratégia de treinamento cirúrgico dos residentes ou na profilaxia com antibióticos ${ }^{(33,36,39)}$. No entanto, Wykoff et al. descreveram em um serviço universitário, taxas decrescentes, mesmo com advento da cirurgia sem sutura: entre 1984 e 1994, 0,09\%; entre 1995 e 2001, 0,05\% e, entre 2002 e 2009, 0,025\% ${ }^{(40)}$. Incidência em grandes séries de casos encontrados recentemente na China de $0,11 \%$ ${ }^{(32)}$ e nos Estados Unidos da América de 0,04\% ${ }^{(34)}$ exemplificam diferenças regionais.

A incidência de endoftalmite pós-cirurgia de glaucoma varia entre 1,1\% e 2,2\% em 5 anos ${ }^{(41-45)}$. Nestes casos, a infecção pela bolha pode se desenvolver anos após a cirurgia e o paciente pode não relacionar os sintomas à cirurgia de trabeculectomia ${ }^{(46-}$ 50). Assim, a endoftalmite relacionada à bolha filtrante é classificada como manifestação precoce, até 1 mês após a cirurgia e, naquela com manifestação tardia, após 1 mês da cirurgia ${ }^{(51-53)}$. As infecções de manifestação tardia são mais frequentes e associadas a microrganismos diferentes da endoftalmite de manifestação precoce ${ }^{(3,51)}$. O uso de mitomicina, mudança de técnica cirúrgica para flap com base fórnice e não realização de trabeculectomia em região inferior são fatores que podem influenciar a taxa de endoftalmite ao longo dos anos.

A incidência de endoftalmite pós-vitrectomia via pars plana (VVPP) é entre $0,021 \%$ e $0,09 \%{ }^{(10,54-56)}$. A cirurgia de vitrectomia via pars plana com instrumental de 25 gauge e vitrectomia transconjuntival sem sutura (transconjunctival sutureless vitrectomy, TSV) vem sendo cada vez mais frequente, desde que os estudos de segurança e viabilidade foram publicados em 2010. Estas mudanças técnicas nas

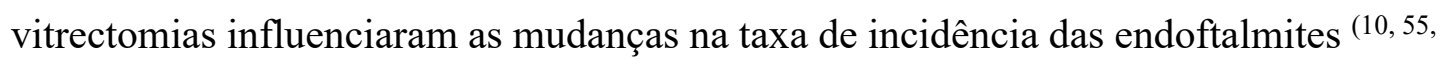
57).

Com a aprovação das injeções intravítreas de antiangiogênico, pelo Food and Drug Administration (FDA), em dezembro de 2004, surgem os casos de endoftalmite após injeções intravítreas. A incidência de endoftalmite pós-injeção intravítrea de antiangiogênicos varia entre $0,008 \%$ e $0,092 \%{ }^{(58-60)}$.

A incidência de endoftalmite pós-trauma, dentre todos os casos de endoftalmite (Cornut et al.) $^{(61)}$ ou dentre casos pós trauma aberto (Essex et al.) ${ }^{(62)}$, foi de 6,8\%, podendo ser maior na presença de corpo estranho intraocular. 
As endoftalmites endógenas, que resultam de uma bacteremia ou fungemia, são mais raras e correspondem entre 5\% e 15\% de todas as endoftalmites ${ }^{(63)}$. Em análise de estudo de pacientes hospitalizados com infecção hematogênica, a incidência de endoftalmite endógena presumida foi de $0,05 \%$, sendo $0,4 \%$ entre pacientes com fungemia e $0,04 \%$ entre pacientes com bacteremia ${ }^{(20)}$. As endoftalmites endógenas resultam caracteristicamente após disseminação hematogênica em indivíduos com doença crônica, imunossuprimidos e/ou uso de cateter central.

\subsection{Fatores de risco para endoftalmite aguda pós-cirurgia de catarata}

Fatores de risco no pré-operatório incluem condições clínicas sistêmicas (diabetes mellitus, imunossupressão, infecção ativa sistêmica) e oculares (blefarite crônica, obstrução do canal lacrimal, colírio contaminado, usuário de lente de contato, prótese ocular no olho contralateral) do paciente ${ }^{(2,19)}$. Fatores de risco no intraoperatório incluem tempo de cirurgia prolongado, implante secundário de lente intraocular, rotura da cápsula posterior, perda vítrea, prolapso de íris, soluções ou lente intraocular contaminadas ${ }^{(64)}$. Dentre os fatores de risco no pós-operatório, constam vazamento pela ferida e encarceramento do vítreo na incisão, dentre outros. Cuidados perioperatórios devem ser feitos com uso de antissepsia com iodo povidona (evidência grau II) ${ }^{(58,65)}$.

\subsection{Diagnóstico clínico de endoftalmite}

A endoftalmite bacteriana pós-operatória aguda é caracterizada pela dor, perda visual súbita e olho vermelho associada à inflamação intraocular intensa, podendo apresentar-se com fibrina e/ou hipópio. Edema palpebral, congestão conjuntival, inflamação vítrea e vasculite de retina podem ser observados. As endoftalmites póscirurgia de catarata, quando ocorrem em até 6 semanas após o procedimento, são definidas como agudas ${ }^{(8)}$. A endoftalmite pós-operatória crônica, geralmente, apresenta-se com um quadro indolente, que pode se estender por semanas a meses após 
a cirurgia, com episódios recorrentes de inflamação do segmento anterior e turvação vítrea, com possível melhora parcial e temporária com uso de corticoide ${ }^{(63,66,67)}$.

Nos casos associados à bolha filtrante, envolvimento purulento da bolha pode ser observado assim como inflamação de humor aquoso e vítreo ${ }^{(68)}$. As endoftalmites fúngicas são mais indolentes e com menos dor ${ }^{(58)}$. As endoftalmites pós-trauma perfurante são graves e rapidamente progressivas ${ }^{(62,69)}$.

Complementando o exame clínico, o ultrassom ocular pode auxiliar no diagnóstico da endoftalmite com achados de organização vítrea em casos em que existe opacidade de meios dificultando a visualização do segmento posterior, como nas endoftalmites pós-ceratite pode ser útil ${ }^{(58)}$.

\subsection{Diagnóstico diferencial}

Alguns diagnósticos diferenciais como outras causas inflamatórias não infecciosas em um pós-operatório devem ser considerados. A síndrome tóxica no segmento anterior (toxic anterior segment syndrome, TASS) é uma inflamação estéril com reação inflamatória moderada a intensa, nas primeiras 12 a 48 horas após a cirurgia ${ }^{(5)}$. TASS pode ser decorrente da exposição de vários materiais estranhos ao olho, como a lente intraocular e compostos usados para desinfecção. Sua apresentação é mais precoce que a endoftalmite infecciosa e os sinais ficam localizados no segmento anterior. Restos de córtex do cristalino e presença de medicamentos, dentre outras causas, também podem estar associados à inflamação intraocular estéril. 


\subsection{Agentes etiológicos da endoftalmite}

Os microrganismos isolados com maior frequência podem diferir na dependência da fonte de infecção e do caráter agudo (precoce) ou tardio (crônico) da endoftalmite (Tabela 1). As endoftalmites agudas pós-cirurgia de catarata são causadas, em sua grande maioria, por microrganismos provenientes da microbiota ocular, como Staphylococcus coagulase-negativa (SCoN), Staphylococcus aureus, Streptococcus grupo viridans e, em menor proporção, outros cocos Gram-positivos e bacilos Gram-negativos. $\mathrm{Na}$ endoftalmite pós-operatória tardia, os patógenos envolvidos são de baixa virulência, como Propionibacterium acnes (renomeado Cutibacterium acne), algumas espécies de estreptococcos e fungos ${ }^{(70)}$. $\mathrm{Na}$ endoftalmite pós-traumática, podem ser isolados os mesmos microrganismos causadores de endoftalmite pós-operatória e alguns microrganismos ambientais ${ }^{(61)}$.

Tabela 1 - Fonte de infecção de endoftalmite e organismos causais mais frequentes

\begin{tabular}{llll}
\hline Fonte de infecção & \multicolumn{2}{l}{ Microrganismos mais frequentes } & \\
\hline Pós-operatório agudo & $\begin{array}{l}\text { Staphylococcus } \\
\text { coagulase-negativa }\end{array}$ & $\begin{array}{l}\text { Staphylococcus } \\
\text { aureus }\end{array}$ & Streptococcus spp \\
Pós-operatório crônico & $\begin{array}{l}\text { Propionibacterium } \\
\text { acnes }\end{array}$ & Candida parapsilosis & $\begin{array}{l}\text { Staphylococcus } \\
\text { coagulase-negativa }\end{array}$ \\
$\begin{array}{l}\text { Associado à bolha } \\
\text { filtrante }\end{array}$ & Streptococcus spp & Staphylococcus spp & $\begin{array}{l}\text { Haemophilus } \\
\text { influenzae }\end{array}$ \\
Pós-injeção intravítrea & $\begin{array}{l}\text { Staphylococcus } \\
\text { coagulase-negativa } \\
\text { Pós-trauma }\end{array}$ & Streptococcus viridans & \\
Endógena & Bacillus cereus & \\
Fúngica & Candida albicans & Aspergillus spp & Staphylococcus \\
Bacteriana & Bacillus cereus & $\begin{array}{l}\text { Klebsiella } \\
\text { pneumoniae }\end{array}$ \\
\hline
\end{tabular}




\subsection{Métodos para identificação do agente etiológico}

\subsubsection{Visualização direta}

O agente etiológico pode ser observado e caracterizado em esfregaço em lâmina com colorações específicas, muitas vezes, sendo o primeiro passo para caracterização de amostras de bactérias. No entanto, a identificação exata do agente etiológico nem sempre é possível. Tan et al. identificaram o agente na lâmina com coloração de Gram em apenas 38\% dos casos, sendo os resultados compatíveis com os obtidos da cultura ${ }^{(71)}$. Já, Pongsachareonnont et al. identificaram o agente em 17\% das lâminas, porém em $28 \%$ dos casos o resultado não foi compatível com o da cultura (72).

\subsubsection{Cultura}

A cultura convencional consiste na semeadura do material vítreo em meios de cultura para os agentes mais prevalentes de acordo com a fonte de infecção, i.e. ágar sangue, ágar chocolate, ágar Sabouraud e caldo de tioglicolato. (Tabela 2). A positividade da cultura convencional varia entre $34 \%$ e $69 \%(7-9,22,73,74)$. Após a semeadura diretamente nas placas, o encaminhamento deve ser imediato ao laboratório. Estas condições ideais nem sempre são parte da realidade de muitos centros cirúrgicos, resultando em uma baixa sensibilidade do método.

No intuito de melhorar a positividade na cultura, algumas propostas foram levantadas. Desta forma, como realizado no EVS, o filtro de membrana de acetato de celulose pode ser usado em amostras vítreas com grande volume, porém com baixa concentração de microrganismo, como o obtido da bolsa coletora do vitreófago nos casos submetidos à cirurgia de vitrectomia. $\mathrm{O}$ filtro de membrana permite concentrar o inóculo e os fragmentos no filtro; estes são colocados nos meios líquidos ou sólidos, aumentando a chance de crescimento ${ }^{(6,75)}$. Rachitskaya et al. compararam resultados com uso do filtro de membrana e com os frascos de hemocultura aeróbio e anaeróbio de adulto. (6) Eles concluíram que nas suspeitas de micobactéria ou fungos filamentosos, a combinação dos dois é melhor ou a utilização do filtro é melhor que o 
frasco apenas. Estes autores sugerem que se a suspeita for de bactéria Gram-positiva, o frasco é melhor que o filtro sozinho. A grande limitação do uso do filtro de membrana é a dificuldade de se obter os materiais necessários (filtro, membrana de acetato, bomba de vácuo), de seu manuseio, além de laboratório disponível para processar efetivamente. Deve-se considerar também a disponibilidade limitada de laboratório nos períodos noturnos e final de semana ${ }^{(75)}$.

A depender do volume da amostra, técnicas alternativas de cultura podem ser selecionadas. A rotina mais preconizada é a inoculação direta do espécime em meio de cultura que inclui ágar sangue em atmosfera com $5 \%$ de $\mathrm{CO}_{2}$ para a maioria das bactérias e fungos, ágar chocolate para organismos fastidiosos como Neisseria gonorrhoeae e Haemophilus influenzae, ágar Sabouraud para fungo e caldo de tioglicolato para anaeróbios (Tabela 2).

Tabela 2 - Meios de cultura e microrganismos isolados

\begin{tabular}{ll}
\hline Meios & Microrganismos isolados \\
\hline Ágar sangue & $\begin{array}{l}\text { Bactérias aeróbias e anaeróbias facultativos, incluindo } \\
\text { Pseudomonas aeruginosa, Staphylococcus aureus, } \\
\text { Staphylococcus epidermidis e Streptococcus pneumoniae }\end{array}$ \\
Ágar chocolate & $\begin{array}{l}\text { Bactérias aeróbias e anaeróbias facultativos, incluindo } \\
\text { Baemophlus influenzae, Neisseria gonorrhea e }\end{array}$ \\
Caldo de tioglicolato & $\begin{array}{l}\text { Bactérias aeróbias, anaeróbios facultativos e anaeróbios } \\
\text { estritos }\end{array}$ \\
Ágar Sabouraud & Fungo \\
Lowestein Jensen & Micobactéria \\
BHI (Brain Heart Infusion) & Bactérias aeróbias e anaeróbias facultativos, fungos e \\
& leveduras \\
Frasco de hemocultura infantil & Bactérias aeróbias e anaeróbias facultativas, fungos e \\
(aeróbio) & $\begin{array}{l}\text { leveduras } \\
\text { Frasco de hemocultura adulto } \\
\text { (anaeróbio) }\end{array}$ \\
Frasco Myco/ F & Bactérias anaeróbias facultativas e anaeróbias estritas \\
\hline
\end{tabular}


Outra proposta para facilitar a identificação do microrganismo é o uso do frasco de hemocultura. Em 1989, os primeiros casos de uso de frasco de hemocultura foram descritos por Joondeph et al., em estudo retrospectivo com 83 casos; a positividade foi de $93 \%{ }^{(75)}$. Estudos prospectivos, após esse primeiro relato, demonstraram a superioridade dos resultados no frasco de hemocultura: a mediana de positividade para cultura convencional foi $35,7 \%(12,2 \%$ a $72 \%)$ versus para cultura em frasco de

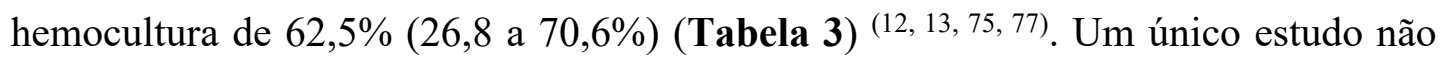
mostrou diferença do uso do frasco de hemocultura em relação à cultura convencional (71). Nesse estudo, a positividade da cultura convencional foi $72 \%$, melhor do que em outros estudos, sendo excluídos os casos com uso de antibiótico prévio.

Recentemente, nosso grupo publicou um estudo retrospectivo que avaliou o uso do frasco de hemocultura nas endoftalmites ${ }^{(14)}$. Foram incluídas 20 amostras analisadas na cultura convencional, no período entre 2010 e 2011, com positividade de $35 \%$, e 34 amostras analisadas com frasco de hemocultura infantil, no período entre 2012 e 2015, com melhora da positividade para $64,7 \%{ }^{(14)}$. O frasco de hemocultura infantil foi desenvolvido para amostras com volumes menores de até 3 mililitros $(\mathrm{mL})$, resultando em maior positividade em relação ao frasco de hemocultura de adulto (volume até $10 \mathrm{~mL})^{(78)}$. Desta forma, estes frascos foram usados no presente estudo cujas amostras oculares são de pequeno volume ${ }^{(8,91)}$. Embora o uso do frasco de hemocultura de adulto anaeróbio juntamente com o frasco aeróbio infantil possa aumentar a positividade na identificação, este último tem disponibilidade restrita aos serviços com público infantil ${ }^{(71)}$. Assim, desde que haja otimização da coleta do fluxo de encaminhamento do material e da estrutura do laboratório de Microbiologia, bons resultados podem ser obtidos, mesmo utilizando frasco de hemocultura de adulto. Nos estudos de Pongsachareonnont et al., a sensibilidade da cultura usando frasco de hemocultura de adulto foi $26,8 \%$, diferentemente dos outros estudos, e, hipoteticamente, esta baixa sensibilidade poderia ser atribuída ao pequeno volume usado $(0,1 \mathrm{~mL})^{(72)}$.

O uso do frasco de hemocultura infantil apresenta inúmeras vantagens em relação à semeadura nos meios: preparação padronizada; facilidade de inoculação (pode ser realizada pelo próprio oftalmologista mesmo sem experiência prévia; útil sobretudo em horários noturnos e final de semana); pouco volume de amostra (mínimo 
de $0,1 \mathrm{~mL}$ ), especificamente para o frasco de hemocultura infantil; facilidade de transporte para o laboratório, podendo ser realizado em até 12 horas sem interferir na sensibilidade; pode ser disponível e útil em centros oftalmológicos sem um laboratório de microbiologia próximo (e.g., áreas rurais); possibilidade de armazenamento em temperatura ambiente, antes do uso. Nos casos com uso prévio de antibiótico intravítreo, os frascos de hemocultura usados no presente estudo (BACTEC Pediatric Plus Aerobic, Becton Dickinson and Co, BD, New Jersey EUA) têm resinas que se ligam aos antibióticos, podendo aumentar a possibilidade de isolamento da bactéria (79-81). O frasco de hemocultura aeróbio permite também a identificação de Candida albicans, pois este meio também favorece o crescimento e a identificação de alguns fungos $(77,82)$.

No entanto, o uso do frasco de hemocultura apresenta algumas limitações, tais como: necessidade de volume mínimo de $0,1 \mathrm{~mL}$ e necessidade de laboratórios equipados para análise do frasco (incubadora para análise). O custo do frasco torna-se maior em relação ao uso das placas de ágar. O custo aproximado descrito foi USD 7,50 para cultura convencional e USD 10,00 com uso de frasco de hemocultura ${ }^{(77)}$. No Brasil, o custo do frasco de hemocultura infantil é em torno de $\mathrm{R} \$ 15,00$. Outra limitação do frasco de hemocultura aeróbio infantil é a possibilidade de detectar apenas bactérias aeróbias e alguns tipos de fungos. Nos locais em que se utiliza técnica de reação em cadeia da polimerase (polymerase chain reaction, PCR), existe a possibilidade de identificar agentes virais, assim como novos agentes, como torque vírus ${ }^{(83)}$.

A identificação de determinados agentes, como Haemophillus influenzae e Propionibacterium acne, é prejudicada no frasco de hemocultura de adulto. $H$. influenzae requer cofatores encontrados no sangue, como dinucleótido de nicotinamida e adenina e hemina para seu crescimento. Propionibacterium acne pode precisar de, pelo menos, 2 semanas para seu crescimento ${ }^{(75)}$.

Embora a maior parte dos laboratórios usem meios sólidos, no intuito de melhorar a positividade das culturas e, com base em nossos resultados previamente publicados e citados, em nosso serviço são adotados, como método convencional de cultura, os frascos de hemocultura infantil para o diagnóstico etiológico nas 
endoftalmites. É importante ressaltar que países, como França e Estados Unidos da América, utilizam os meios sólidos. Nestes países, talvez o interesse em melhorias nas técnicas de Microbiologia seja menor pelo provável uso rotineiro das técnicas de biologia molecular e/ou pela disponibilidade de laboratórios mais eficientes ${ }^{(77)}$. 
Tabela 3 - Estudos comparando a positividade da cultura convencional e o uso de frasco de hemocultura em casos de endoftalmite

\begin{tabular}{|c|c|c|c|c|c|c|}
\hline \multirow{2}{*}{ Autor, ano } & \multirow{2}{*}{ País } & \multirow{2}{*}{$\begin{array}{l}\text { Período do } \\
\text { estudo }\end{array}$} & \multirow{2}{*}{$\mathbf{N}$} & \multirow{2}{*}{$\begin{array}{l}\text { Frasco de } \\
\text { Hemocultura }\end{array}$} & \multicolumn{2}{|c|}{ Positividade } \\
\hline & & & & & Cultura convencional (\%) & Frasco de hemocultura (\%) \\
\hline Joondeph et al., 1989 & EUA & 1979-1988 & 14 & Adulto aeróbio & 36 & 64 \\
\hline Yospaiboon et al., 2005 & Tailândia & - & 27 & Adulto aeróbio & 26 & 52 \\
\hline Kratz et al., 2006 & Israel & $2003-2005$ & 13 & Infantil aeróbio & 54 & 69 \\
\hline Eser et al., 2007 & Turquia & $2001-2005$ & 48 & Infantil aeróbio & - & 71 \\
\hline Tan et al., 2011 & Holanda & $2001-2010$ & 85 & Adulto aeróbio/anaeróbio & 72 & 69 \\
\hline Tanaka et al., 2019 & Brasil & $2010-2015$ & 54 & Infantil aeróbio & 35 & 65 \\
\hline Thariya et al., 2016 & Tailândia & $2008-2014$ & 305 & Adulto aeróbio & 32 & 45 \\
\hline Pongsachareonnont et al., 2017 & Tailândia & 2012-2013 & 29 & Adulto aeróbio & 12 & 27 \\
\hline
\end{tabular}




\subsubsection{Espectrometria de massas MALDI-TOF}

O método clássico de cultura é preciso e sensível, porém, demorado. MALDITOF, uma aplicação da espectrometria de massas à microbiologia, permite um diagnóstico muito mais rápido. A sigla MALDI-TOF significa Matrix Associated Laser Desorption-Ionization-Time of Flight. O princípio da tecnologia MALDI-TOF é que íons de massa e cargas diferentes quando submetidos a um campo elétrico deslocam-se, e a distância percorrida em determinado tempo é em função da relação carga/massa. A primeira etapa para realização do MALDI-TOF consiste em misturar a amostra com a matriz. O depósito formado pela amostra e pela matriz é colocado sobre uma placa metálica. A placa é introduzida no espectrômetro de massa e feixes de laser ultravioleta de determinados comprimentos de onda são emitidos sobre cada depósito. A matriz absorve a energia do laser e ocorre evaporação da amostra com a formação de íons com massas diferentes. Os íons formados com carga movimentamse sob influência do campo elétrico, atravessam grades de extração e atingem o tubo de voo, em cuja extremidade encontra-se o detector. Os menores íons chegam em primeiro tempo ao detector. O tempo de voo de cada partícula até o detector é utilizado para calcular sua massa. A soma de íons analisados forma o espectro de massas da amostra analisada. O eixo das abscissas corresponde à relação massa/carga; no eixo das ordenadas, encontra-se a intensidade do sinal que é relacionada à quantidade de íons de mesma massa/carga. Os princípios da tecnologia citada estão ilustrados na Figura 1 e foram explicitados por Croxatto et al. em $2012^{(15)}$.

A espectrometria de massas começou a ser aplicada nos anos $1970{ }^{(84)}$. Mas, o grande impulso para desenvolvimento da tecnologia foi dado, em 1987, por Tanaka et al. que conseguiram ionizar grandes moléculas por laser ao utilizar matriz composta por partículas de cobalto e glicerol ${ }^{(85)}$. Diversos estudos analisaram o desempenho da técnica para identificação de bactérias Gram-positivas, Gram-negativas e leveduras diretamente de frascos de hemocultura $(15,86,87)$.

A principal vantagem da tecnologia de EM MALDI-TOF sobre outras técnicas laboratoriais para identificação de microrganismos é a agilidade para obtenção do resultado. Entre a confecção do depósito e a leitura final, um resultado isolado pode 
ser obtido em cerca de 30 a 60 minutos ${ }^{(16,17)}$. Os dados de EMs são comparados a banco de dados que contém espectros de referência ou superespectros (MYLA/SARAMIS, BioMerieux) para identificação de espécies. Outra vantagem desta tecnologia é que já pode ser utilizada nos laboratórios de Microbiologia Clínica, pois dispõe de registro na ANVISA para uma das duas plataformas existentes, VITEK MS. No entanto, testes para identificar a resistência aos antimicrobianos e antifúngicos ainda não estão sendo realizados, sendo ainda um fator limitante em algumas circunstâncias ${ }^{(88)}$.

O aparelho de espectrometria de massas com MALDI-TOF, ainda de alto custo, vem sendo adquirido no Brasil em laboratórios com grande demanda, pois substituem a mão de obra humana por método automatizado. No HCFMUSP, o primeiro equipamento foi introduzido em 2014. No entanto, no cenário mundial há tendência de automatização dos métodos para diagnóstico microbiológico ${ }^{(17,88)}$. Nos laboratórios com disponibilidade deste equipamento, EM MALDI-TOF está sendo utilizado juntamente com a cultura convencional com meios sólidos de rotina, acelerando a identificação do microrganismo. Desta forma, EM MALDI-TOF tem proporcionado um rápido, barato e confiável método para identificação de bactérias e fungos ${ }^{(87)}$.

Diferentemente da EM MALDI-TOF com a cultura convencional, EM MALDI-TOF direto, isto é, identificação direta do microrganismo a partir de hemocultura positiva tem impactado as decisões clínicas no que diz respeito ao tratamento precoce direcionado à fonte de infecção da bacteremia, o manejo para controlar a disseminação e a escolha de terapia antimicrobiana. Assim, como mencionado anteriormente, EM MALDI-TOF é um método rápido para identificação de isolados de bactéria em hemocultura, contraponto às técnicas de cultura convencional $^{(89)}$.

Estudos recentes vêm demonstrando altas taxas de correlação entre os resultados produzidos pela EM MALDI-TOF e as técnicas de identificação de referência como PCR e sequenciamento ${ }^{(17)}$. Para identificação na rotina microbiógica de agentes como de Staphilococcus, Streptococcus e Enterococcus, EM MALDI-TOF apresentou taxas de concordância entre $99 \%$ e 100\%. A identificação precisa pode 
orientar o uso de antibióticos adequados. Assim, por exemplo, sabe-se que isolados de Enterococcus faecalis são, geralmente, sensíveis a ampicilina, e Enteroccus faecium, usualmente, são resistentes a esta droga. A elevada acurácia na identificação torna-se bem importante e útil para a prática clínica. A identificação de Bacillus spp por técnicas manuais e automatizadas é um desafio no laboratório clínico ${ }^{(17)}$. Usualmente, os resultados não são liberados até a espécie. No entanto, a técnica de EM MALDITOF vem demonstrando bons resultados, chegando a $100 \%$ de sensibilidade ${ }^{(86)}$.

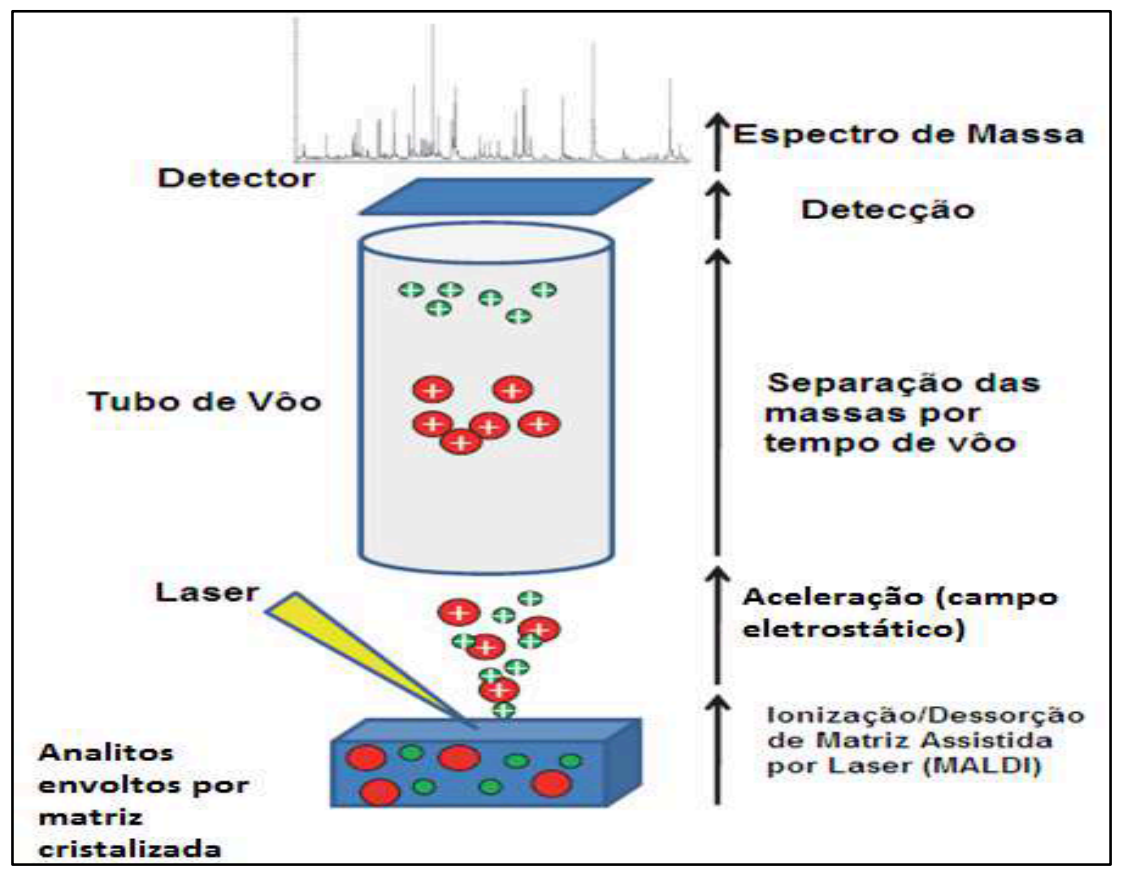

Fonte: adaptado de Croxatto et al., 2012 ${ }^{(15)}$.

Figura 1 - Princípio da tecnologia de espectrometria de massa por ionização/ dessorção a laser assistida por matriz por tempo de voo (MALDI-TOF)

Huang et al. publicaram os resultados obtidos em estudo pré e pós a intervenção da escolha da antibioticoterapia que mediu a incorporação desta tecnologia em 501 pacientes com hemoculturas positivas com e sem intervenção. Os resultados foram comparados com uma série histórica de 256 pacientes. A comparação dos resultados do grupo, cujas culturas foram identificadas de forma convencional contra o grupo no qual as identificações foram obtidas por EM MALDI-TOF mostrou redução no tempo de identificação (84 vs 55,9 horas, $\mathrm{p}<0,001)$ e impacto no tempo da escolha adequada 
do antibiótico (30,1 vs 20,4 horas, $\mathrm{p}=0,21)$, além do tempo para otimização da antibioticoterapia $(90,3$ vs 46,3 horas, $\mathrm{p}<0,001)$. As taxas de mortalidade foram reduzidas $(20,3 \%$ vs $14,5 \%)$, assim como tempo de internação em unidade de terapia intensiva (14,9 vs 8,3 dias). A mudança de antibiótico conduzida pelo resultado precoce foi associada a uma tendência na redução de mortalidade na análise multivariada. Desta forma, o impacto clínico da agilidade na identificação dos patógenos responsáveis por infecção de corrente sanguínea pode ser expressivo, com redução de mortalidade ${ }^{(90)}$.

A EM MALDI-TOF tem especial importância na identificação de patógenos que requerem longo tempo de incubação ou que apresentam inativação bioquímica para algumas provas de identificação, como são os anaeróbios por exemplo. A identificação de fungos por EM MALDI-TOF é uma revolução na micologia. As técnicas fenotípicas para identificação de leveduras, ou mesmo micromorfologia para identificação de fungos filamentosos podem exigir muitos dias para finalização. Assim, a identificação de leveduras do gênero Candida por EM MALDI-TOF vem demonstrando um desempenho superior às técnicas fenotípicas comerciais.Em muitas ocasiões, a agilidade e a precisão da análise proteômica poderão substituir a necessidade de utilização de ferramentas moleculares ${ }^{91}$.

A aplicação da EM MALDI-TOF também em um futuro próximo estender-seá a detecção de resistência bacteriana. A caracterização do mecanismo de resistência por tal técnica poderá antecipar a escolha terapêutica, podendo impactar diretamente nas taxas de morbidade e mortalidade dos processos infecciosos, sobretudo, em pacientes hospitalizados e imunodeprimidos ${ }^{(86,91)}$.

Observando o cenário para diagnóstico microbiológico com a espectrometria de massa, e diante da necessidade da diminuição do tempo do diagnóstico nos casos de endoftalmite para tentar melhorar o prognóstico reservado, em revisão de literatura realizada no início do estudo, não havia publicação com descrição da análise do humor vítreo, utilizando a análise direta do frasco de hemocultura com a EM MALDI-TOF, sendo esta a proposta principal de nosso estudo. 


\subsubsection{Biologia molecular}

Além da cultura e espectrometria de massas, métodos de biologia molecular vêm se mostrando úteis na caracterização dos agentes infecciosos, destacando-se a técnica da PCR (polymerase chain reaction, PCR). Com a PCR em tempo real, outras técnicas em pesquisa, como microarray DNA e hibridização fluorescente in situ com ácido nuclêico peptídeo (PNA-FISH) podem diminuir o tempo de diagnóstico do agente causal nas endoftalmites entre 20 minutos e 24 horas ${ }^{(92-94)}$. O alto custo e a complexidade de algumas dessas tecnologias e a necessidade de equipe treinada podem dificultar a implantação destes métodos na prática clínica.

Os estudos em endoftalmite usando a técnica da PCR para diagnóstico iniciaram-se em 1994. Chiquet et al. observaram que a PCR é complementar ao método de cultura convencional ${ }^{(95)}$. Eles observaram uma sensibilidade da PCR panbacteriana similar à cultura em 100 amostras de casos com endoftalmite aguda póscatarata, mas a combinação de ambos os métodos permitiu a identificação da bactéria em $87 \%$ dos casos, sendo destes $25 \%$ com cultura negativa. Brillat-Zaratzian et al. mostraram que a técnica da PCR e cultura convencional foram técnicas complementares e a combinação das duas aumentou em $21 \%$ a sensibilidade do diagnóstico microbiológico ${ }^{(3)}$. Bispo et al. descreveram que a detecção bacteriana melhorou de 47,6\% na cultura para 95,3\% com PCR, demonstrando uma boa sensibilidade e rápido diagnóstico nos casos de endoftalmite bacteriana ${ }^{(96)}$. Assim, PCR pode se mostrar mais útil, sobretudo quando a cultura é negativa ou para detecção de bactérias de crescimento lento. A maioria dos estudos detectam sequências altamente conservadas do genoma de bactérias e fungos, gene 16S rRNA ou gene18S rRNA, respectivamente, com necessidade de sequenciamento posterior para identificação do patógeno ${ }^{(97)}$.

Além da PCR pan-bacteriano, como mencionado acima, a PCR pode ter como alvo genes específicos de um gênero ou espécie. Chips de DNA ou DNA microarrays colecionam muitas sondas específicas de hibridização em um mesmo meio ${ }^{(98)}$. São técnicas ainda em desenvolvimento, mais específicas e sensíveis que as com panbactéria. Os novos métodos moleculares, sobretudo o sequenciamento da próxima 
geração (metagenômica), podem auxiliar no diagnóstico etiológico nas amostras negativas na cultura e/ou na EM MALDI-TOF ${ }^{(99)}$.

A técnica de PCR apresenta, no entanto, algumas limitações. Resultados falsopositivos podem ocorrer pelo maior risco de contaminação, especialmente, nas etapas de manipulação dos reagentes ${ }^{(98)}$. Para tal limitação, a PCR quantitativa pode auxiliar a diferenciar uma infecção de uma contaminação pelo número de cópias da sequência específica bacteriana ${ }^{(97)}$. A cultura também é essencial para validar o resultado molecular com perspectivas clínicas. A dificuldade de extração do DNA de alguns microrganismos também pode resultar em falso-negativo. $\mathrm{O}$ amplo uso da técnica da PCR é limitado também pelo custo, cerca de 10 vezes mais caro que a cultura. Outra limitação da PCR é a necessidade de cerca de 2 e 4 dias para realização de sequenciamento para identificação do microrganismo. Além disso, a PCR não consegue identificar a susceptibilidade do microrganismo aos antibióticos $(97,100,101)$. Entretanto, recentemente, estudos capazes de detectar genes de resistência vêm sendo desenvolvidos, como por exemplo, gene de Staphylococci responsável pela resistência a meticilina ${ }^{(98)}$.

$\mathrm{Na}$ literatura, assim como na Divisão de Laboratório Central (DLC), HCFMUSP, PCR para agentes virais (vírus da família Herpes, HIV) e para toxoplasmose são métodos já bem estabelecidos e de grande utilidade para o diagnóstico das uveítes ${ }^{(102)}$. A PCR em tempo real para bactérias e fungos, incorporada na rotina da prática clínica de alguns países, ainda não é uma realidade em nosso País para amostras oculares $(95,96,102)$.

\subsection{Diagnóstico etiológico de endoftalmite no Brasil}

No Brasil, as cirurgias oftalmológicas acompanham os avanços tecnológicos observados mundialmente. No entanto, dados estatísticos relativos à incidência de endoftalmites com identificação dos agentes infecciosos são escassos.

Em uma casuística de hospital universitário em São Paulo, no período entre 2002 e 2008, a incidência de endoftalmite após cirurgia de catarata foi 0,29\% ( 73 casos 
dentre 24.590 cirurgias de catarata). A cultura foi positiva em $63,1 \%$ dos casos. Os agentes mais frequentemente identificados foram Staphylococci coagulase negativo $(56,5 \%)$ e Streptococcus viridans $(15 \%)^{(33)}$. Outra casuística em centro especializado em Oftalmologia descreveu uma taxa de infecção de 0,06\% em um total de 31.999 cirurgias intraoculares, no período entre 2004 e 2009, com principal agente etiológico Pseudomonas aeruginosa em 42,1\% dos casos ${ }^{(103)}$. Giampani et al. descreveram em 164 olhos de crianças com glaucoma congênito ou de desenvolvimento submetidos à trabeculectomia com mitomicina C, no período entre 1991 e 2001, taxa de endoftalmite de 4,9\% (104). Alguns relatos de surtos de endoftalmite pós facoemulsificação foram descritos, tendo como principal agente Pseudomonas aeruginosa $^{(105)}$.

Melo et al. ${ }^{(22)}$ descreveram o espectro de microrganismos isolados de pacientes com endoftalmite bacteriana. A positividade na cultura ou coloração Gram foi 46\%, sendo bactéria Gram-positiva (Staphylococcus coagulase-negativa em 48\%, Streptococcus viridans em 18\% e Staphylococcus aureus em 13\%) em 91\% dos casos. Bispo et al. ${ }^{(106)}$ foram os pioneiros no Brasil a desenvolver o diagnóstico molecular nas endoftalmites bacterianas. Bispo et al., usando dois ensaios de PCR, SYBR green 16S rDNA-based universal PCR e um Multiplex Gram-specific TaqMan-Based PCR, aumentaram a positividade de identificação do patógeno em dez amostras de humor aquoso e em 11 amostras de humor vítreo de pacientes com endoftalmite de 47,6\% na cultura para $95,2 \%{ }^{(96)}$.

Como mencionado anteriormente, a PCR no diagnóstico das infecções oculares

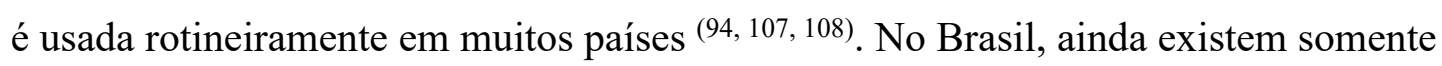
os trabalhos publicados pelo grupo de Hofling et al. ${ }^{(96,109)}$.

\subsection{Opções de tratamento}

O tratamento das endoftalmites baseia-se na seleção de antimicrobianos efetivos e seguros. Inicialmente, é indicada uma terapia de amplo espectro para organismos Gram-positivos e Gram-negativos, i.e. vancomicina e ceftazidima ou amicacina intravítreos, e a recomendação atual baseia-se no Endophthalmitis 
Vitrectomy Study (EVS) ${ }^{(8)}$. Neste estudo, foram incluídos 420 pacientes com endoftalmite aguda pós-operatória após cirurgia de catarata ou implante secundário de lente intraocular (LIO). Resultado visual em relação à acuidade visual inicial foi analisado quando realizada, inicialmente, biópsia vítrea ou VVPP. As principais observações foram que pacientes com acuidade visual de percepção de luz tinham melhor prognóstico com VVPP inicial, e nos pacientes com acuidade visual melhor ou igual a movimentos de mãos, o procedimento inicial não interferiu ${ }^{(8)}$. No entanto, estas recomendações vêm sendo contestadas por vários estudos. Estudos vêm indicando benefício de VVPP inicial em outras situações clínicas; endoftalmites pós outros procedimentos podem ter agentes causais mais agressivos e VVPP inicial pode ser benéfico; uso de antibiótico deve ser guiado pelo agente detectado e a sensibilidade ao antimicrobiano $^{(110-113)}$.

Embora o tratamento inicial seja com antibióticos de amplo espectro, programas para otimização do uso de antibiótico sistêmico são feitos para reduzir a resistência dos antibióticos ao redor do mundo, diminuir custo e reduzir a mortalidade e morbidade de pacientes, utilizando antibiótico direcionado e no menor tempo possível. Estes programas são os "Antimicrobial stewardship programs" (114, 115). Para isso, é necessário o envolvimento de toda equipe que assiste o paciente, assim como é fundamental que o médico prescritor esteja ciente das resistências aos antimicrobianos baseado no Antibiotic test sensitivity (ATS) local, optando pelo antibiótico mais apropriado. A cultura identificando o microrganismo corretamente permite também a indicação do antibiótico mais sensível e redução do uso de antibióticos de amplo espectro por tempo prolongado. Novas técnicas para um diagnóstico rápido vêm sendo implementadas em todas áreas da Medicina e cada vez mais são necessárias também na Oftalmologia e, sobretudo, em nosso País ${ }^{(116)}$.

\subsection{Prognóstico visual}

Tratamento precoce está associado a um prognóstico visual melhor. O prognóstico também varia conforme o agente etiológico. Infecção por Staphylococcus

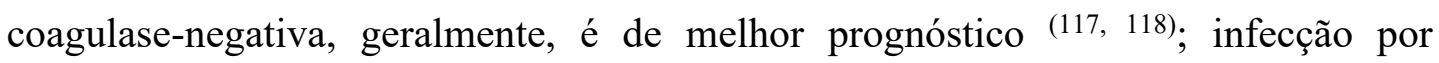


Staphylococcus aureus, Streptococcus e bactérias Gram-negativas, geralmente, são mais graves e com pior prognóstico ${ }^{(119-121)}$. Com as técnicas que permitem a identificação do agente etiológico em menos de 24 horas, estudos baseados nos diferentes agentes detectados devem ser revisados quanto à conduta e prognóstico. 
4 Pacientes e Métodos 


\section{PACIENTES E MÉTODOS}

\subsection{Desenho do estudo}

Estudo prospectivo observacional.

\subsection{Pacientes}

No presente estudo, foram incluídos pacientes atendidos no HCFMUSP ou em outros serviços externos de Oftalmologia previamente cadastrados (termo de anuência do responsável) no período entre outubro de 2015 e junho de 2017 (21 meses).

O critério de inclusão foram pacientes com suspeita de endoftalmite exógena ou endógena. As endoftalmites exógenas (porta de entrada do patógeno externo) foram aquelas relacionadas à cirurgia intraocular prévia, trauma ou procedimentos (remoção de sutura, injeções intravítreas). Quanto às endoftalmites endógenas, os fatores predisponentes foram uso prolongado de antibioticoterapia, hiperalimentação intravenosa e/ou condição clínica/terapia imunossupressora.

Os casos associados à úlcera de córnea foram excluídos no presente estudo pela dificuldade inicial de caracterizar o diagnóstico de endoftalmite.

Os seguintes dados clínicos foram analisados: fonte de infecção (cirurgia, trauma, procedimento, condição clínica predisponente), material a ser analisado (forma de coleta, material), uso de antibiótico (tópico, sistêmico, intravítreo), acuidade visual corrigida (pré-operatória, no diagnóstico da endoftalmite e 3 meses póstratamento) e serviço de origem.

O estudo foi aprovado pela Comissão para Análise de Projetos de Pesquisa (CapPesq) do HCFMUSP sob número CAAE: 36514614.4.0000.0068 (Anexo 9.1). Todos os pacientes foram convidados a participar do estudo após obtenção do Termo de Consentimento Livre e Esclarecido (Anexo 9.2). 


\subsection{Coleta do material}

Diante de suspeita de endoftalmite, a conduta inicial foi definida pela equipe do médico responsável pelo paciente, variando de acordo com a disponibilidade de recursos técnicos e humanos e de normas internas de cada Serviço.

O humor vítreo, diluído ou não, foi coletado por biópsia ou VVPP. O humor aquoso foi coletado por paracentese em alguns casos.

Nos casos nos quais a biópsia vítrea foi a primeira intervenção, esta foi realizada com agulha de 22 a 26 gauge conectada à seringa de 3 ou $5 \mathrm{ml}$, seguida de injeção intravítrea (IIV) de vancomicina $(1 \mathrm{mg} / 0,1 \mathrm{~mL})$ e ceftazidima $(2,25 \mathrm{mg} / 0,1$ $\mathrm{mL}$ ). Nos casos submetidos à biópsia vítrea com resposta parcial ou piora do quadro clínico, vitrectomia com nova coleta de material era programada. Nos casos com VVPP como $1^{\mathrm{o}}$ procedimento, após a coleta do material, antibiótico intravítreo foi injetado, como citado acima, conforme preconizado pelo Guia de Utilização de Antiinfecciosos e Recomendações para a Prevenção de Infecções Hospitalares ${ }^{(122)}$.

Nos casos de VVPP, realizada sempre no centro cirúrgico, tanto material diluído como não diluído foram analisados (Figura 2). O material não diluído ( $0,5 \mathrm{a}$ $1 \mathrm{ml}$ ) foi obtido por aspiração manual com seringa conectada diretamente na sonda do vitreófago no início do procedimento. Este material foi dividido para análise por cultura e para futura análise por PCR (100 a $200 \mu \mathrm{lem}$ microtubo estéril). Nos casos de endoftalmite pós-operatória aguda e endógena em imunocompetente, o material foi inoculado no frasco de hemocultura infantil (BACTEC Pediatric Plus Aerobic, Becton Dickinson and Co, BD, New Jersey EUA); nos casos de endoftalmite pós-operatória crônica, endógena em imunodeprimidos e pós-trauma, o material foi encaminhado em tubo estéril seco (Falcon $\left.{ }^{\circledR}\right)$ e, no laboratório, dentro do fluxo laminar, o material foi diluído, aumentando-se seu volume e distribuído nos meios para cultura aeróbia, anaeróbia e fungo (caldo de tioglicolato e frasco de hemocultura para micobacteria). O material para análise futura pela PCR foi armazenado a $-20^{\circ} \mathrm{C}$. 
Em relação ao material diluído, este foi obtido a partir da bolsa coletora do aparelho de vitreófago. Após o término da cirurgia, foi feita a assepsia da bolsa coletora do cassete com álcool 70\%, o material diluído não filtrado foi coletado com seringa de $20 \mathrm{~mL}$ e agulha de 20 gauge em um volume total de $18 \mathrm{~mL}$, o qual foi encaminhado para cultura de microrganismos aeróbios $(3 \mathrm{~mL}$, frasco de hemocultura infantil, BACTEC Pediatric Plus Aerobic, Becton Dickinson and Co, BD, New Jersey EUA), para cultura de microrganismos anaeróbicos $(10 \mathrm{~mL}$, frasco de hemocultura anaeróbia de adulto, Becton Dickinson Diagnostic Instrument Systems, Sparks, MD, EUA) e para cultura de micobactéria e fungos ( $5 \mathrm{~mL}$, frasco Myco F, Becton Dickinson Diagnostic Instrument Systems, Sparks, MD, EUA). Em casos selecionados, o restante do material diluído do cassete (aproximadamente, $140 \mathrm{~mL}$ ) foi filtrado com membrana de acetato de celulose de 0,22 $\mu \mathrm{m}$ (Sartorius AG, Alemanha, $47 \mathrm{~mm}$ ). A membrana pelo qual o material diluído foi filtrado foi dividida em seis fragmentos e cada fragmento foi semeado nos seguintes meios: ágar sangue, ágar chocolate, ágar Sabouraud, meio Lowenstein Jensen e caldo de tioglicolato. Figura 2 ilustra este fluxograma.

Em três pacientes, no procedimento de vitrectomia, foram também coletadas amostras de humor aquoso pela paracentese da câmara anterior.

O transporte do material foi realizado em recipiente apropriado, de acordo com a norma da ANVISA (RDC 20/2014), com notificação do horário da coleta e do recebimento pelo laboratório, além dos demais dados contidos na ficha. O tempo entre a coleta e entrega no laboratório não excedeu 12 horas ${ }^{(123)}$. 




*Armazenado para futuras análises

Figura 2 - Fluxograma da coleta e envio de material intraocular para análise nos casos suspeitos de endoftalmite

\subsection{Análise do material ocular}

\subsubsection{Microbiologia convencional}

As amostras inoculadas em frascos de hemocultura infantil foram inseridas em aparelhos automatizados (Bactec FX system $^{\mathrm{TM}}$, BD, New Jersey, MD, EUA) de incubação por período máximo de 5 dias. As amostras positivas foram em parte semeadas em meios convencionais (ágar sangue, ágar chocolate e ágar Sabouraud) e incubadas por 48 horas em estufas de microaerofilia ou em atmosfera ambiente e o ágar Sabouraud por 30 dias (Tabela 2). A identificação foi realizada por EM MALDI- 
TOF e teste de sensibilidade por método automatizado VITEK-2 (Biomèrieux, França). As amostras enviadas em tubo seco estéril Falcon ${ }^{\circledR}$ foram diluídas em $3 \mathrm{~mL}$ de água destilada no laboratório de Microbiologia e semeadas nos seguintes meios: caldo de tioglicolato $(1 \mathrm{~mL})$, frasco aeróbio de hemocultura infantil $(1 \mathrm{~mL})$ e frasco de hemocultura para micobactéria $(1 \mathrm{~mL})$.

O tempo para diagnóstico (turnaround time - TAT) da cultura convencional foi considerado a partir da entrada no aparelho automatizado até resultado pela metodologia automatizada (Figura 3).

Os meios convencionais enviados com a membrana de acetato de celulose também foram incubados por 48 horas em estufas de microaerofilia ou em atmosfera ambiente, e o ágar Sabouraud por 30 dias.

A identificação e o teste de sensibilidade aos antimicrobianos foram realizados por metodologia automatizada VITEK-2 (Biomèrieux, França).

\subsubsection{Espectrometria de massas MALDI-TOF direto}

Os frascos de hemocultura, positivos após incubação inicial, foram analisados com a identificação direta pela EM MALDI-TOF, além da cultura convencional (ágar sangue, ágar chocolate e ágar Sabouraud), como mencionado no item 4.4.1. Foi realizado protocolo de extração descrito por Pulcrano et al. ${ }^{(124)}$. O protocolo de extração consistiu em três passos para extração de proteína com teste desenvolvido pelo laboratório (in-house) para identificação direta pela EM MALDI-TOF:

- Alíquota de 4 mL foi submetida a vigorosa agitação para lise do conteúdo, depositada em microtubo (Vacutainer ${ }^{\circledR}$ STT $^{\mathrm{TM}}$, Becton Dickinson and Co., UK), e centrifugada a $2.500 \mathrm{rpm}$, por 15 minutos;

- Sobrenadante foi descartado e lavado com $1 \mathrm{~mL}$ de água de cromatografia líquida de alta performance (high performance liquid chromatography, HPLC) e realizada nova centrifugação (13.000 rpm por 2 minutos);

- O sobrenadante foi descartado e 1,0 $\mu \mathrm{L}$ do remanescente foram aplicados em placa metálica e ao analito foi adicionado $1,0 \mu \mathrm{L}$ de matriz de ácido alfaciano-hidrocinâmico. 
Em casos de suspeita de leveduras ou hifas pela análise do Gram, foi necessário realizar modificação na etapa final da extração. Nesses casos, antes de realizar a última etapa, o sedimento foi diluído em $1.200 \mathrm{~mL}$ de etanol a 70\%. Depois de nova agitação e centrifugação, o sedimento foi exposto ao ácido fórmico $70 \%$ e à acetonitrila.

As análises foram realizadas no instrumento VITEK ${ }^{\circledR}$ MS (Biomérieux, França). Os espectros obtidos foram comparados a base de dados do fabricante que contém espectros de referência de bactérias, fungos e micobactérias (IVD database v3.2, Biomérieux, Marcy-1'Etoile, França). A compatibilidade entre o espectro do analito e o espectro de referência acima de $60 \%$ foi considerada suficiente para identificação correta do microrganismo (www.biomerieux.com).

O TAT da identificação direta pela EM MALDI-TOF foi considerado a partir da entrada no aparelho automatizado até saída do aparelho, após positivar e foi acrescentada 1 hora (tempo para realizar a extração da proteína para identificação direta pela EM MALDI-TOF do agente etiológico). As amostras positivas no frasco de hemocultura, após a incubação inicial, que foram coletadas durante a noite foram armazenadas a $4^{\circ} \mathrm{C}$ e analisadas no dia seguinte pela manhã; e, aquelas que foram coletadas durante o final de semana foram analisadas na manhã da segunda-feira seguinte (Figura 3).

Crescimento polimicrobiano foi definido como isolamento de mais que uma espécie ou cepa de microrganismo de uma mesma amostra. 


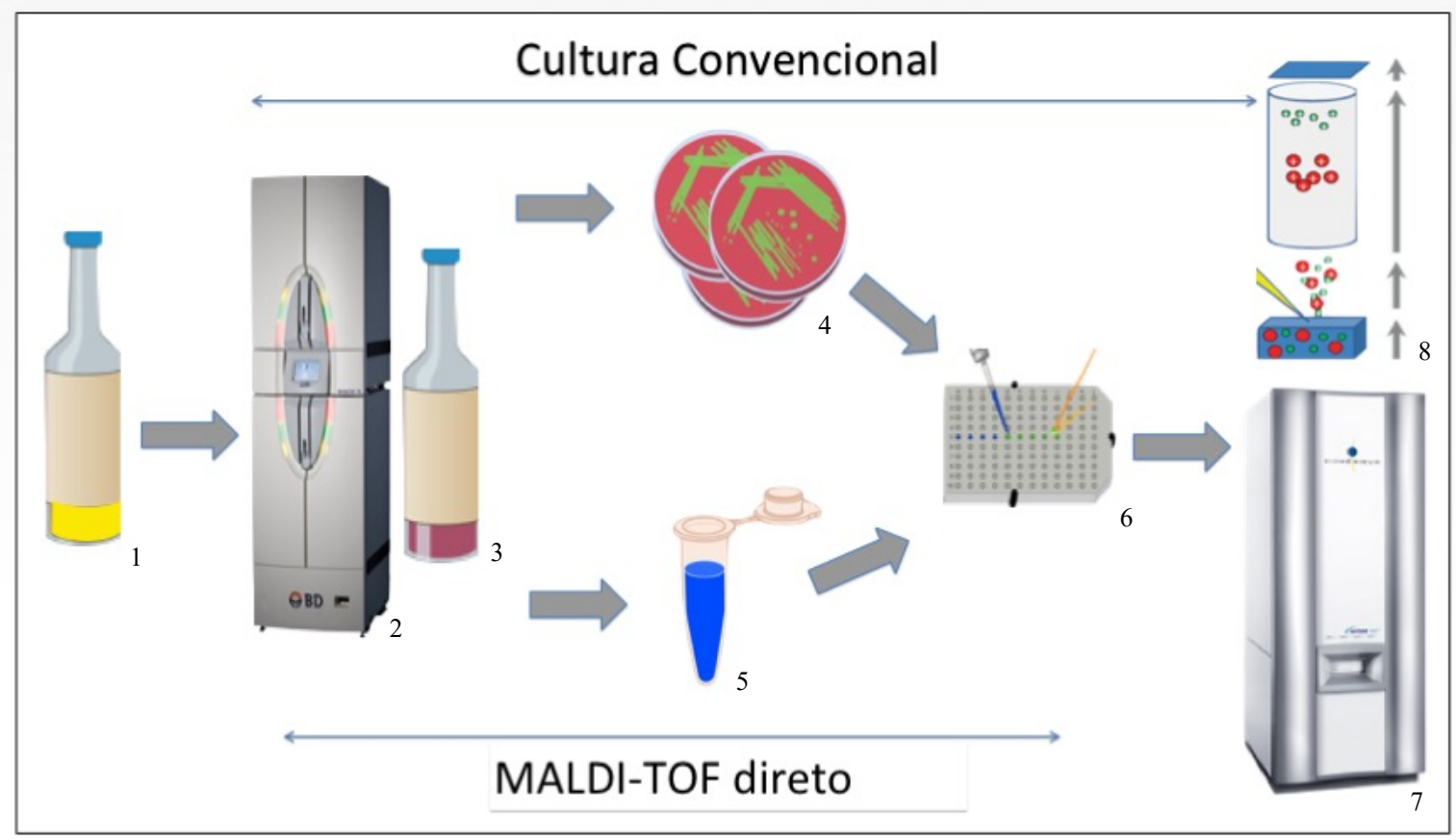

Figura 3 - Etapas seguidas pela cultura convencional e pela identificação direta pela espectrometria de massas MALDI-TOF. A linha em azul define o tempo para diagnóstico (turnaround time, TAT)

${ }^{1}$ Frasco de hemocultura aeróbio infantil com material intraocular (humor vítreo ou humor aquoso) inoculado; ${ }^{2}$ Aparelho automatizado (Bactec FX System ${ }^{\mathrm{TM}}$, BD, New Jersey, MD, EUA) de incubação dos frascos de hemocultura; ${ }^{3}$ Frasco de hemocultura infantil após positivar; ${ }^{4}$ Meios convencionais semeados com amostras positivas após incubação em estufas de microaerofilia ou em atmosfera ambiente; ${ }^{5}$ Alíquota de amostra positiva em microtubo submetida a protocolo de extração protéica; ${ }^{6}$ Preparo placa metálica e adição de matriz; ${ }^{7}$ Aparelho de espectrometria de massas VITEK® (Biomérieux, França); ${ }^{8}$ Ionização e dessorção a laser assistida por matriz por tempo de voo que ocorre no aparelho VITEK MS®.

\subsection{Análise estatística}

A análise estatística foi realizada com software comercial (SPPS, ver 22.0; SPSS, Chicago, IL, EUA). Foram apresentadas as identificações pela EM MALDITOF relativamente à cultura convencional com uso de frequências absolutas e relativas. Os tempos de identificação por método foram descritos com uso de mediana, mínimo e máximo e comparados nos casos identificados por ambos os métodos, tanto no total como para cada microrganismo e também com e sem diluição com uso de 
testes Wilcoxon pareado (Signed-ranks). As associações de positividade no diagnóstico foram avaliadas conforme o uso de antibiótico e biópsia e o prognóstico visual dos pacientes com agente mais comum com uso dos testes Qui-quadrado ou Exato de Fisher. Consideramos a diferença estatisticamente significante para valores de $\mathrm{p}$ menores que $5 \%(\mathrm{p}<0,05)$. 
5 Resultados 


\section{RESULTADOS}

No período entre outubro de 2015 e junho de 2017, foram coletadas amostras de 96 pacientes com suspeita de endoftalmite exógena ou endógena atendidos no HCFMUSP ou em serviços externos de Oftalmologia. Dois casos foram excluídos por contaminação da amostra coletada. Após a análise dos prontuários de pacientes com evolução, no mínimo, de 3 meses, sete casos foram excluídos por não preencherem os critérios de inclusão, sendo definidos posteriormente os seguintes diagnósticos: uveíte posterior por sífilis $(n=2)$, núcleo no vítreo $(n=1)$, hemorragia vítrea $(n=1)$, síndrome tóxica do segmento anterior $(\mathrm{n}=1)$, glaucoma neovascular $(\mathrm{n}=1)$, expansão de gás pós vitrectomia $(\mathrm{n}=1)$. Em todos esses casos, as culturas foram negativas. Desta forma, no presente estudo foram avaliados 87 casos (Tabela 4 e Figura 3).

Dos 87 casos com clínica compatível com endoftalmite, obteve-se cultura positiva em 53 pacientes $(60,9 \%)$, sendo negativa em 34 pacientes $(39,1 \%)$. Das 53 amostras positivas, em 47 casos, foi identificada a mesma bactéria pela cultura convencional e pela análise direta com EM MALDI-TOF. Em dois casos, a cultura convencional identificou dois agentes (cultura polimicrobiana); em um caso foi realizada somente a cultura convencional. Em três casos, foram identificados fungos (Figura 4). 


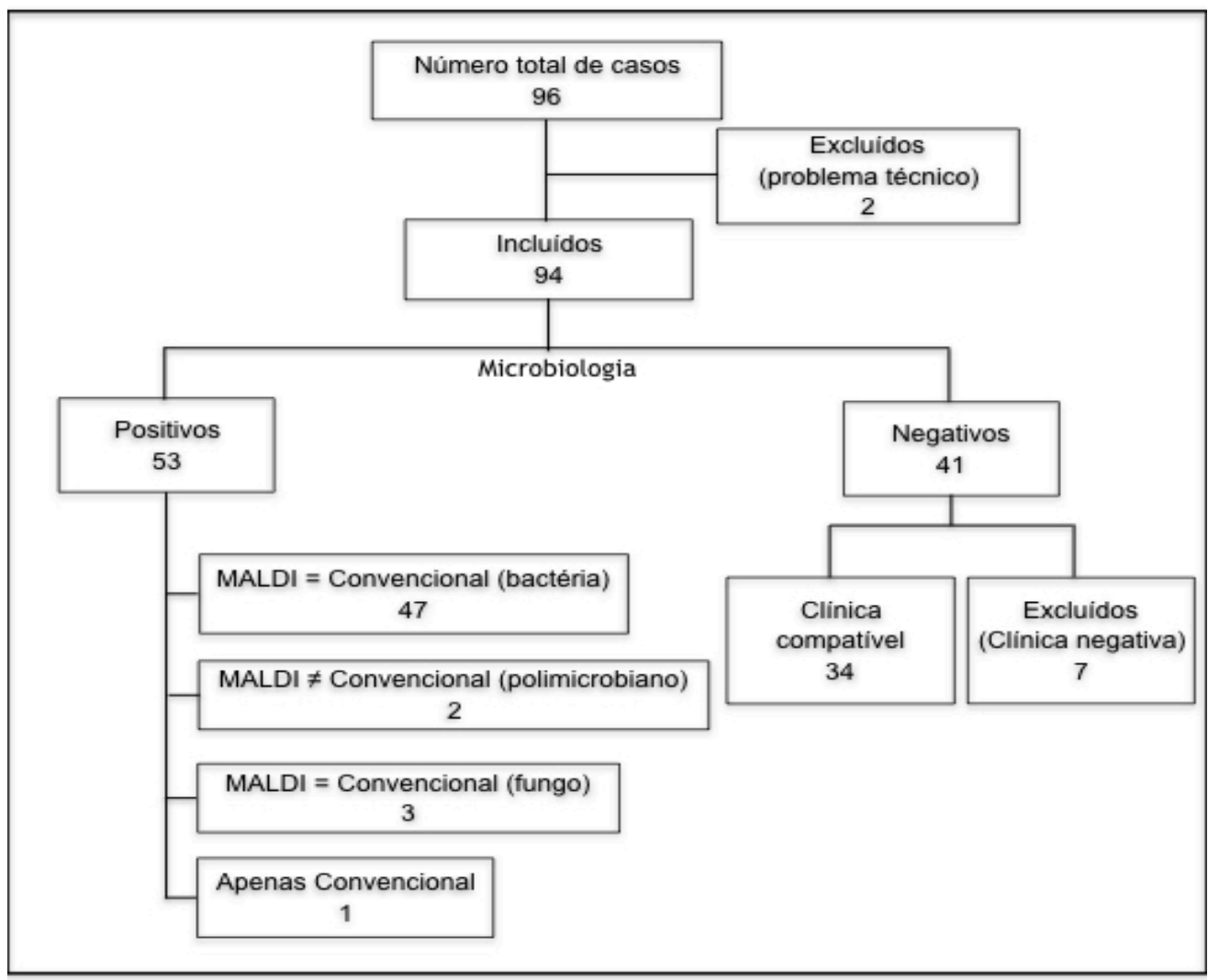

Figura 4 - Organograma com o número de casos com suspeita de endoftalmite exógena ou endógena incluídos no estudo

Dentre os 50 casos bacterianos, o agente mais prevalente foi Staphylococcus epidermidis $(\mathrm{n}=15)$, seguido por Staphylococcus aureus $(\mathrm{n}=6)$, Streptococcus pneumoniae $(\mathrm{n}=9)$ e Streptococcus do grupo viridans $(\mathrm{n}=5)$, entre outros agentes (Tabela 4). Os microrganismos Gram-positivos foram isolados em 46 casos $(86,7 \%)$ e Gram-negativos em seis casos $(11,3 \%)$. Não foi identificada nenhuma bactéria anaeróbia. Dentre os casos por Streptococcus do grupo viridans, foram identificadas as seguintes espécies do grupo: $S$. mitis oralis $(\mathrm{n}=2), S$. sanguinis $(\mathrm{n}=2)$ e $S$. gordonii $(n=1)$.

Os três casos de fungos identificados foram leveduras da espécie Candida albicans (Tabela 4). Não foi identificado fungo filamentoso nesta casuística. Para a detecção de fungos pela identificação direta do frasco de hemocultura utilizando EM MALDI-TOF, as últimas etapas de extração da proteína foram modificadas, conforme descrito na Seção 4.4.2 (página 33). 
Tabela 4 - Agentes etiológicos detectados na cultura de amostras de humor vítreo/humor aquoso de 53 casos de endoftalmite

\begin{tabular}{|c|c|c|c|c|c|c|c|c|c|}
\hline \multirow[b]{2}{*}{ Descrição } & \multirow[b]{2}{*}{$\mathbf{n}$} & \multirow[b]{2}{*}{$\%$} & \multicolumn{7}{|c|}{ Fonte de infecção $^{a}$} \\
\hline & & & $\mathbf{C}$ & $\mathbf{G}$ & VVP & Injeção & Trauma & Endógena & $\begin{array}{l}\text { Remoção de } \\
\text { sutura }\end{array}$ \\
\hline \multicolumn{10}{|l|}{ Gram-positivos } \\
\hline Staphylococcus epidermidis & 15 & 27,3 & 9 & & 1 & 3 & & & 2 \\
\hline Staphylococcus aureus & 6 & 10,9 & 1 & & & 1 & 1 & 3 & \\
\hline Staphylococcus haemolyticus & 2 & 3,6 & & & & 2 & & & \\
\hline Staphylococcus lugdunensis & 2 & 3,6 & & & 1 & 1 & & & \\
\hline Staphylococcus saprophyticus & 1 & 1,8 & & & & & 1 & & \\
\hline Streptococcus pneumoniae & 9 & 16,4 & 2 & 4 & & & & & 3 \\
\hline \multicolumn{10}{|l|}{ Streptococcus do grupo Viridans } \\
\hline Streptococcus mitis oralis & 2 & 3,6 & & & & & 2 & & \\
\hline Streptococcus sanguinis & 2 & 3,6 & & 2 & & & & & \\
\hline Streptococccus gordonii & 1 & 1,8 & & 1 & & & & & \\
\hline Abiotrophia & 2 & 3,6 & 2 & & & & & & \\
\hline Bacillus cereus complex & 3 & 5,5 & 2 & & & & 1 & & \\
\hline Enterococcus faecalis & 1 & 1,8 & 1 & & & & & & \\
\hline \multicolumn{10}{|l|}{ Gram-negativos } \\
\hline Haemophilus influenzae & 1 & 1,8 & & 1 & & & & & \\
\hline Pseudomonas aeruginosa & 1 & 1,8 & 1 & & & & & & \\
\hline Serratia marcencens & 2 & 3,6 & & 1 & & & 1 & & \\
\hline Neisseria mucosa & 1 & 1,8 & 1 & & & & & & \\
\hline Enterobacter cloacae complex & 1 & 1,8 & & & & & 1 & & \\
\hline \multicolumn{10}{|l|}{ Fungos } \\
\hline Candida albicans & 3 & 5,5 & & & & & & 3 & \\
\hline Total de agentes & 55 & 100 & & & & & & & \\
\hline
\end{tabular}

${ }^{a} \mathrm{C}=$ catarata; $\mathrm{G}=$ glaucoma; $\mathrm{VPP}=$ vitrectomia via pars plana; Injeção= injeção intravítrea 
A cultura polimicrobiana foi encontrada em dois casos (pós-trauma e pósfacectomia). Nos dois casos, a identificação pelo método direto com EM MALDI-TOF foi possível apenas para um dos agentes, conforme descrito nos dados da Tabela 5. A identificação dos dois agentes só foi possível pela cultura convencional.

Tabela 5 - Culturas de amostras de humor vítreo de dois pacientes com endoftalmite com resultados polimicrobianos

\begin{tabular}{lll}
\hline Fonte da infecção & \multicolumn{1}{c}{ Cultura convencional } & ID direto por MALDI-TOF \\
\hline Trauma & Enterobacter cloacae complex & Enterobacter cloacae complex \\
& Bacillus sp & Não identificado \\
& & \\
Facectomia & Streptococcus sanguinis & Streptococcus sanguinis \\
& Neisseria mucosa & Não identificado \\
\hline
\end{tabular}

\subsection{Aplicação da análise direta do humor vítreo em frasco de hemocultura pela EM MALDI-TOF no diagnóstico das endoftalmites}

Dos 87 pacientes incluídos, todas as amostras oculares dos 53 pacientes com cultura convencional positiva, exceto um paciente, foram analisadas concomitantemente pelo método de identificação direta com EM MALDI-TOF. Os resultados foram coincidentes em 50 pacientes, sendo em três pacientes de etiologia fúngica e em 47 pacientes de etiologia bacteriana (Tabelas 6 e 7).

O fungo Candida albicans foi identificado em três pacientes com endoftalmite endógena, tanto no frasco de hemocultura infantil aeróbio (humor vítreo e humor vítreo não diluído) como no frasco MYCO F coletado do cassete (humor vítreo diluído). Os tempos de identificação pelo método convencional e pela identificação direta com EM MALDI-TOF foram avaliados apenas do frasco de hemocultura aeróbio infantil das amostras diluídas dos três pacientes, conforme é apresentado nos dados da Tabela 6. 
Dentre 47 pacientes com identificação de patógeno bacteriano, obteve-se 61 amostras para análise e validação do método de identificação direta com EM MALDITOF (Tabela 7). Em 36 pacientes, as amostras positivas foram únicas: 22 de biópsia vítrea e 14 de vitrectomia. Em 11 pacientes, obteve-se duas ou três amostras positivas do mesmo paciente. Em três pacientes, no procedimento de vitrectomia, foram também coletadas amostras de humor aquoso. Algumas variáveis consideradas para análise posterior foram: uso de antibiótico intravítreo prévio, material colhido da $1^{\mathrm{a}} \mathrm{e} / \mathrm{ou}$ da $2^{\mathrm{a}}$ intervenção.

Cinquenta das 61 amostras $(81,1 \%)$ tiveram concordância nas duas análises (Tabela 7). Para as bactérias Gram-positivas, a identificação pelos dois métodos ocorreu em 45 amostras de 56 (80,4\%). Considerando as cinco amostras de endoftalmite por bactérias Gram-negativas, todas foram identificadas pelos dois métodos.

O tempo de identificação (turnaround time - TAT) após subcultura na cultura convencional e o TAT na identificação por análise direta com EM MALDI-TOF foram calculados para as 61 amostras. A mediana do tempo para identificação da cultura convencional e da análise direta do frasco de hemocultura infantil pela EM MALDITOF foram 44,8 horas (variação entre 18,5 e 187,5 horas) e 15,00 horas (variação de 3,1 a 94,0 horas), respectivamente; e ao comparar somente as amostras identificadas pelos dois métodos, a mediana da cultura convencional foi 50,6 horas (variação entre 18,5 e 187,5 horas) $(\mathrm{p}<0,001)$ (Figura 5). Em 100\% das amostras, a análise direta com EM MALDI-TOF permitiu identificação do agente etiológico da endoftalmite com maior rapidez, havendo uma redução média de 30 horas ou uma redução mediana de $67,6 \%$.

Os principais resultados da validação do método de identificação por análise direta com EM MALDI-TOF estão publicados em Diagnostic Microbiology and Infection Disease em 2017 (Anexo 9.3).

O tempo médio para identificação variou conforme a bactéria identificada, porém para cada patógeno a variação foi pequena entre as várias amostras. Nos dados da Tabela 8, é apresentado o tempo de identificação para cada agente pelos dois métodos. 
Tabela 6 - Tempo de identificação (turnaround time, TAT) de Candida albicans pela cultura convencional e pela análise direta do humor vítreo diluído inoculado em frasco de hemocultura infantil pela EM MALDI-TOF de amostras de três pacientes com suspeita de endoftalmite endógena

\begin{tabular}{llcc}
\hline Caso & Amostra & $\begin{array}{c}\text { TAT }^{\mathrm{a}} \text { ID }^{\mathrm{b}} \text { após } \\
\text { subcultura (horas) }\end{array}$ & $\begin{array}{c}\text { TAT ID MALDI-TOF } \\
\text { direto (horas) }\end{array}$ \\
\hline 1 & Vitrectomia (diluído) & 61,9 & 29,5 \\
2 & Vitrectomia (diluído) & 89,4 & 48,1 \\
3 & Vitrectomia (diluído) & 36,1 & 4,6 \\
\hline
\end{tabular}

${ }^{\mathrm{a}} \mathrm{TAT}=$ turn around time $;{ }^{\mathrm{b}} \mathrm{ID}=$ identificação

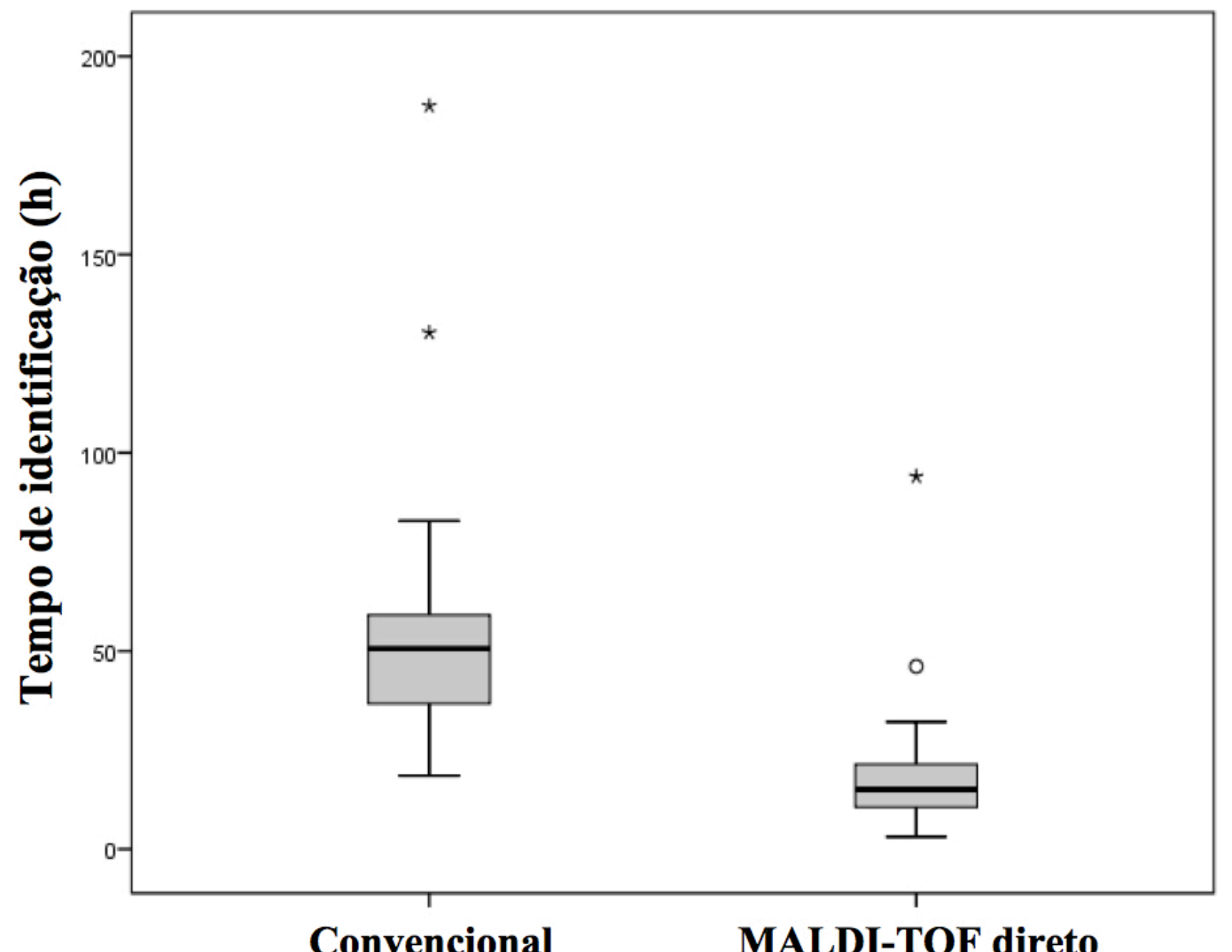

Figura 5 - Box-and-Whiskers plot do tempo de identificação (em horas) para os patógenos identificados no humor vítreo de 37 pacientes (39 amostras) com endoftalmite, na cultura convencional e na análise direta pela EM MALDI-TOF $(\mathrm{p}<0,001)$. Valores extremos (outliers) foram marcados com asteriscos. 
Tabela 7 - Identificação do patógeno bacteriano pela cultura convencional e pela análise direta pela MALDI-TOF direto com o tempo de identificação (turnaround time, TAT) em 61 amostras oculares de 47 pacientes com suspeita de endoftalmite

\begin{tabular}{|c|c|c|c|c|c|}
\hline Caso & Amostra & Fonte da infecção & Agente $^{a}$ & $\begin{array}{l}\text { TAT }^{\mathbf{b}} \text { ID }^{\mathrm{c}} \text { após } \\
\text { subcultura (horas) }\end{array}$ & $\begin{array}{l}\text { TAT ID MALDI-TOF direto } \\
\text { (horas) }\end{array}$ \\
\hline 1 & Biópsia vítrea & Endógena & S. aureus & 33,20 & 10,60 \\
\hline 2 & Vitrectomia $^{\mathrm{d}}$ & Trauma & S. aureus & 43,90 & 4,10 \\
\hline 3 & Vitrectomia $^{\mathrm{d}}$ & Facoemulsificação & S. aureus & 53,10 & 21,40 \\
\hline \multirow[t]{2}{*}{4} & Vitrectomia & Endógena & S. aureus & 34,90 & 14,70 \\
\hline & Vitrectomia (diluído) & & S. aureus & 34,90 & 19,20 \\
\hline 5 & Vitrectomia & Injeção intravítrea de bevacizumabe & S. aureus & 51,90 & 14,40 \\
\hline \multirow[t]{3}{*}{6} & Biópsia vítrea & Endógena & S. aureus & 28,90 & 8,70 \\
\hline & Vitrectomia & & S. aureus & 44,80 & 22,40 \\
\hline & Vitrectomia (diluído) & & S. aureus & 44,60 & 15,10 \\
\hline 7 & Biópsia vítrea & Injeção intravítrea de triancinolona & S. epidermidis & 58,60 & 23,80 \\
\hline 8 & Biópsia vítrea & Injeção intravítrea de bevacizumabe & S. epidermidis & 36,10 & Não identificado \\
\hline \multirow[t]{2}{*}{9} & Vitrectomia $^{\mathrm{d}}$ & Facectomia extracapsular & S. epidermidis & 59,10 & 24,70 \\
\hline & Vitrectomia (diluído) $^{\mathrm{d}}$ & & S. epidermidis & 60,90 & 26,60 \\
\hline 10 & Biópsia vítrea & Remoção de sutura & S. epidermidis & 55,90 & 25,90 \\
\hline \multirow[t]{3}{*}{11} & Vitrectomia (HA) & Vitrectomia & S. epidermidis & 59,10 & 21,10 \\
\hline & Vitrectomia & & S. epidermidis & 51,90 & 13,10 \\
\hline & Vitrectomia (diluído) & & S. epidermidis & 51,90 & 18,60 \\
\hline 12 & Biópsia vítrea & Facoemulsificação & S. epidermidis & 56,50 & 21,30 \\
\hline 13 & Biópsia vítrea & Facoemulsificação & S. epidermidis & 52,10 & 18,50 \\
\hline 14 & Biópsia vítrea & Remoção de sutura & S. epidermidis & 63,10 & Não identificado \\
\hline 15 & Vitrectomia & Facoemulsificação & S. epidermidis & 50,90 & 19,60 \\
\hline 16 & Vitrectomia & Facoemulsificação & S. epidermidis & 76,90 & Não identificado \\
\hline 17 & Vitrectomia & Facoemulsificação & S. epidermidis & 63,20 & 25,10 \\
\hline 18 & Vitrectomia & Facoemulsificação & S. epidermidis & 50,60 & 22,10 \\
\hline 19 & Vitrectomia $^{\mathrm{d}}$ & Facoemulsificação & S. epidermidis & 55,80 & 32,10 \\
\hline \multirow[t]{2}{*}{20} & Vitrectomia $^{\mathrm{d}}$ & Facoemulsificação & S. epidermidis & 82,80 & 26,40 \\
\hline & Vitrectomia (diluido) $^{\mathrm{d}}$ & & S. epidermidis & 60,00 & 27,20 \\
\hline
\end{tabular}


Tabela 7 (cont.). Identificação do patógeno bacteriano pela cultura convencional e pelo MALDI-TOF direto com o tempo de identificação (turnaround time, TAT) em 61 amostras oculares de 47 pacientes com suspeita de endoftalmite

\begin{tabular}{|c|c|c|c|c|c|}
\hline Caso & Amostra & Fonte da infecção & Agente $^{\text {a }}$ & $\begin{array}{l}\text { TAT }^{\mathrm{b}} \text { ID }^{\mathrm{c}} \text { após } \\
\text { subcultura (horas) }\end{array}$ & $\begin{array}{l}\text { TAT ID MALDI-TOF direto } \\
\text { (horas) }\end{array}$ \\
\hline \multirow[t]{2}{*}{21} & Vitrectomia & Facoemulsificação & S. haemolyticus & 38,80 & 12,60 \\
\hline & Vitrectomia (diluído) & & S. haemolyticus & 59,50 & 14,90 \\
\hline 22 & Vitrectomia & Injeção intravítrea de ranibizumabe & S. haemolyticus & 130,30 & 21,10 \\
\hline \multirow[t]{2}{*}{23} & Vitrectomia & \multirow[t]{2}{*}{ Facoemulsificação } & S. lugdunensis & 60,50 & 19,60 \\
\hline & Vitrectomia (diluído) & & S. lugdunensis & 60,50 & 20,10 \\
\hline 24 & Biópsia vítrea & Injeção intravítrea de bevacizumabe & S. lugdunensis & 61,80 & 14,00 \\
\hline 25 & Vitrectomia (HA) & Trauma & S. saprophyticus & 73,70 & 46,10 \\
\hline 26 & Biópsia vítrea & Facoemulsificação & S. pneumoniae & 36,80 & 4,40 \\
\hline 27 & Biópsia vítrea & Remoção de sutura & S. pneumoniae & 34,70 & 8,00 \\
\hline 28 & Biópsia vítrea & Remoção de sutura & S. pneumoniae & 35,00 & 3,90 \\
\hline 29 & Biópsia vítrea & Remoção de sutura & S. pneumoniae & 38,10 & 12,60 \\
\hline 30 & Biópsia vítrea & Trabeculectomia & S. pneumoniae & 29,10 & 9,30 \\
\hline 31 & Biópsia vítrea & Facectomia extracapsular & S. pneumoniae & 34,70 & Não identificado \\
\hline 32 & Biópsia vítrea & Trabeculectomia & S. pneumoniae & 27,50 & Não identificado \\
\hline 33 & Biópsia vítrea & Trabeculectomia & S. pneumoniae & 36,60 & Não identificado \\
\hline \multirow[t]{2}{*}{34} & Biópsia vítrea & Implante de tubo & S. pneumoniae & 28,20 & Não identificado \\
\hline & Vitrectomia $(\mathrm{HA})^{\mathrm{d}}$ & & S. pneumoniae & 40,20 & Não identificado \\
\hline \multirow[t]{3}{*}{35} & Biópsia vítrea & Trauma & $\mathrm{VGS}^{\mathrm{c}}$ & 41,10 & 3,90 \\
\hline & Vitrectomia $^{\mathrm{d}}$ & & VGS & 50,50 & 13,60 \\
\hline & Vitrectomia (diluido) $^{\mathrm{d}}$ & & VGS & 41,10 & 13,10 \\
\hline 36 & Biópsia vítrea & Trauma & VGS & 39,50 & 8,70 \\
\hline 37 & Biópsia vítrea & Facoemulsificação & VGS & 27,70 & Não identificado \\
\hline 38 & Biópsia vítrea & Trabeculectomia & VGS & 52,10 & Não identificado \\
\hline
\end{tabular}


Tabela 7 (cont.) Identificação do patógeno bacteriano pela cultura convencional e pelo MALDI-TOF direto com o tempo de identificação (turnaround time, TAT) em 61 amostras oculares de 47 pacientes com suspeita de endoftalmite

\begin{tabular}{|c|c|c|c|c|c|}
\hline Caso & Amostra & Fonte da infecção & Agente $^{a}$ & $\begin{array}{l}\text { TAT }^{\mathrm{b}} \text { ID }^{\mathrm{c}} \text { após } \\
\text { subcultura (horas) }\end{array}$ & $\begin{array}{l}\text { TAT ID MALDI-TOF direto } \\
\text { (horas) }\end{array}$ \\
\hline 39 & Vitrectomia & Facectomia extracapsular & Abiotrophia & 187,50 & 94,00 \\
\hline 40 & Vitrectomia & Facoemulsificação & Abiotrophia & 76,80 & Não identificado \\
\hline 41 & $\begin{array}{l}\text { Vitrectomia } \\
\text { Vitrectomia (diluído) }\end{array}$ & Facoemulsificação & $\begin{array}{l}\text { Bacillus sp } \\
\text { Bacillus sp }\end{array}$ & $\begin{array}{l}36,70 \\
36,70\end{array}$ & $\begin{array}{l}10,00 \\
12,10\end{array}$ \\
\hline 42 & Biópsia vítrea & Facectomia extracapsular & Bacillus sp & 18,50 & 18,10 \\
\hline 43 & Vitrectomia & Facoemulsificação & E. faecalis & 39,20 & 4,50 \\
\hline 44 & Vitrectomia & Trabeculectomia & H. influenzae & 63,50 & 15,60 \\
\hline 45 & $\begin{array}{l}\text { Vitrectomia }^{\mathrm{d}} \\
\text { Vitrectomia (diluído) }^{\mathrm{d}}\end{array}$ & Facoemulsificação & $\begin{array}{l}P . \text { aeruginosa } \\
P . \text { aeruginosa }\end{array}$ & $\begin{array}{l}35,10 \\
35,10\end{array}$ & $\begin{array}{l}13,20 \\
13,60\end{array}$ \\
\hline $\begin{array}{l}46 \\
47\end{array}$ & $\begin{array}{l}\text { Biópsia vítrea } \\
\text { Biópsia vítrea }\end{array}$ & $\begin{array}{l}\text { Trauma } \\
\text { Implante de tubo }\end{array}$ & $\begin{array}{l}\text { S. marcencens } \\
\text { S. marcencens }\end{array}$ & $\begin{array}{l}33,50 \\
37,20\end{array}$ & $\begin{array}{l}7,00 \\
3,10\end{array}$ \\
\hline
\end{tabular}

a S. aureus, S. spidermidis, S haemolyticus, $S$. lugdunensis, S. saprophyticus=Staphylococcus; VGS=Streptococcus do grupo viridans; S. pneumoniae=Streptococcus; H. influenzae= Haemophilus; P. aeruginosa= Pseudomonas; E. faecalis= Enterococco; S. marcencens= Serratia

${ }^{\mathrm{b}} \mathrm{TAT}=$ turn around time; ${ }^{\mathrm{c}} \mathrm{ID}=$ identificação; ${ }^{\mathrm{d}}$ após injeção intravítrea de antibiótico. HA= humor aquoso

Todas biópsias vítreas foram não diluídas e sem antibiótico exceto onde marcado diferentemente. 
Tabela 8 - Tempo de identificação (turnaround time, TAT ID) pela cultura convencional e pela análise direta por EM MALDI-TOF conforme cada patógeno nas 39 amostras oculares positivas em ambos os métodos, de 37 pacientes com suspeita de endoftalmite

\begin{tabular}{|c|c|c|c|c|}
\hline \multirow[b]{2}{*}{ Agente $^{a}$} & \multirow[b]{2}{*}{$\mathbf{n}$} & \multicolumn{2}{|c|}{ TAT ID médio (variação) } & \multirow[b]{2}{*}{$\mathbf{p}^{b}$} \\
\hline & & $\begin{array}{c}\text { Após convencional } \\
\text { (horas) }\end{array}$ & $\begin{array}{c}\text { Análise direta por } \\
\text { EM MALDI }\end{array}$ & \\
\hline E. faecalis & 1 & 39,20 & 4,50 & \\
\hline S. marcencens & 2 & $35,35(33,5-37,2)$ & $5,05(3,1-7,0)$ & 0,180 \\
\hline S. pneumoniae & 5 & $35,00(29,1-38,1)$ & $8,00(3,9-12,6)$ & 0,043 \\
\hline$V G S$ & 3 & $41,10(39,5-50,5)$ & $8,70(3,9-13,6)$ & 0,109 \\
\hline P. aeruginosa & 1 & 35,10 & 13,20 & \\
\hline Bacillus sp & 2 & $27,60(18,5-36,7)$ & $14,05(10,0-18,1)$ & 0,180 \\
\hline S. aureus & 7 & $43,90(28,9-53,1)$ & $14,40(4,1-22,4)$ & 0,018 \\
\hline H. influenzae & 1 & 39,20 & 15,60 & \\
\hline S. haemolyticus & 2 & $84,55(38,8-130,3)$ & $16,85(12,6-21,1)$ & 0,180 \\
\hline S. lugdunensis & 2 & $61,15(60,5-61,8)$ & $16,80(14,0-19,6)$ & 0,180 \\
\hline S. epidermidis & 11 & $55,90(50,6-82,8)$ & $23,80(13,1-32,1)$ & 0,003 \\
\hline S. saprophyticus & 1 & 73,70 & 46,10 & \\
\hline Abiotrophia & 1 & 187,50 & 94,00 & \\
\hline
\end{tabular}

Não incluídos casos com amostra positiva em apenas um dos métodos e amostras de humor vítreo diluído.

a E. faecalis $=$ Enterococcus; S.marcencens $=$ Serratia; S. pneumoniae $=$ Streptococcus; P. aeruginosa $=$ Pseudomonas; VGS=Streptococcus do grupo viridans;

S. aureus, S. epidermidis, S. haemolyticus, S. lugdunensis, S. saprophyticus = Staphylococcus. ${ }^{\mathbf{b}}$ teste de Wilcoxon pareado (Signed-ranks).

Dois pacientes (11 e 34) tiveram amostras de humor aquoso e humor vítreo, no humor aquoso, o tempo de identificação foi maior que no humor vítreo. Para o paciente 11, na cultura convencional, o TAT para amostra do humor aquoso foi 59,1 horas, e para amostra do humor vítreo foi 51,9 horas. Na análise direta pela EM MALDI-TOF, o TAT foi 21,1 horas e 13,1 horas, para humor aquoso e humor vítreo, respectivamente. No caso 25 (endoftalmite pós-trauma perfurante), foi identificado o agente apenas pela coleta do humor aquoso e a amostra do humor vítreo foi negativa.

Em todos os 11 casos com material coletado do cassete, os agentes identificados no humor vítreo diluído foram iguais aos identificados no humor vítreo não diluído, aspirado por meio de seringa conectada ao vitreófago. Quatro pacientes 
$(20,32,33$ e 35$)$ tiveram amostras de biópsia no $1^{\mathrm{o}}$ procedimento e de vitrectomia no $2^{\circ}$ procedimento; no paciente em que foram analisadas as duas coletas (35), a identificação do patógeno foi mais rápida nas amostras da biópsia (3,9 vs 13,6, $1^{\text {o }}$ procedimento vs $2^{\circ}$ procedimento). Das oito amostras positivas coletadas após uso de antibiótico intravítreo, em dois pacientes (34 e 35) amostras sem antibiótico também foram coletadas. O tempo de identificação do patógeno foi menor nas amostras sem antibiótico prévio.

Quando o material era suficiente e com intuito de melhorar a sensibilidade das culturas, parte do material vítreo do cassete foi coletado após uso de filtro de membrana e bomba a vácuo; o filtro foi semeado nas placas de cultura convencional (Tabela 9). Das 12 amostras, oito amostras foram positivas: duas só na biópsia, quatro no humor vítreo não diluído, diluído e no filtro de membrana (estes todos com vitrectomia como $1^{\circ}$ procedimento), e um positivo somente no filtro de membrana. Nesta única amostra positiva somente no filtro de membrana, houve possibilidade de contaminação, pois o tempo e a manipulação do cassete não foram adequados. 
Tabela 9 - Positividade das culturas de 12 amostras oculares, nas quais foram usadas filtro de membrana, de pacientes com suspeita de endoftalmite

\begin{tabular}{|c|c|c|c|c|c|}
\hline \multirow[b]{2}{*}{ Agente } & \multirow[b]{2}{*}{ Fonte de infecção } & \multicolumn{4}{|c|}{ Cultura convencional e/ou EM MALDI TOF direto } \\
\hline & & Biópsia vítrea $^{\mathrm{a}}$ & $\begin{array}{l}\text { Humor vitreo } \\
\text { (VVPP) }\end{array}$ & $\begin{array}{l}\text { Humor vitreo diluido } \\
\text { (VVPP) }\end{array}$ & $\begin{array}{l}\text { Filtro de Membrana } \\
\text { (VVPP) }\end{array}$ \\
\hline Staphylococcus aureus & Facoemulsificação & Positivo & Negativo & Negativo & Negativo \\
\hline Abiotrophia & Facectomia extracapsular & NR & Positivo & Positivo & Negativo \\
\hline Streptococcus pneumoniae & Trabeculectomia & Positivo & Negativo & Negativo & Negativo \\
\hline Negativo & Facoemulsificação & NR & Negativo & Negativo & Negativo \\
\hline Negativo & Trabeculectomia & NR & Negativo & Negativo & Negativo \\
\hline Negativo & Injeção intravítrea de gás & NR & Negativo & Negativo & Negativo \\
\hline Negativo & Agulhamento & NR & Negativo & Negativo & Negativo \\
\hline Staphylococcus aureus & Trauma & NR & Positivo & Positivo & Positivo \\
\hline Bacillus SP & Facoemulsificação & NR & Positivo & Positivo & Positivo \\
\hline Staphylococcus haemolyticus & Facoemulsificação & NR & Positivo & Positivo & Positivo \\
\hline Candida albicans & Endógena & NR & Positivo & Positivo & Positivo \\
\hline $\begin{array}{l}\text { Staphylococcus haemolyticus/ } \\
\text { Corynebacterium }\end{array}$ & Vitrectomia & NR & Negativo & Negativo & Positivo $^{b}$ \\
\hline
\end{tabular}

$\mathrm{VVPP}=$ vitrectomia via pars plana; $\mathrm{NR}=$ não realizado






\subsection{Análise dos aspectos clínicos dos casos com endoftalmite}

Dos 87 casos incluídos com suspeita de endoftalmite, 69 (79,3\%) foram associados a procedimentos cirúrgicos: cirurgia de catarata $(n=31 ; 35,6 \%)$, vitrectomia $(n=7 ; 8 \%)$, injeção intravítrea $(n=7 ; 8 \%)$, cirurgia de glaucoma $(n=19 ; 21,8 \%)$ ou retirada de ponto $(n=5 ; 5,7 \%)$. Os demais casos foram associados a trauma $(n=8$; $9,2 \%)$ ou a uma fonte endógena $(n=10 ; 11,5 \%)$ (Tabela 11). Dentre os 87 casos, foi possível detectar o agente etiológico na cultura em 53 amostras, conferindo uma sensibilidade de $60,9 \%$ (Figura 4). No entanto, a positividade da cultura diferiu por tipo de fonte de infecção (Tabela 11). A positividade foi acima de 70\% em várias situações clínicas, tais como casos agudos de pós-operatório de cirurgia de catarata (21 dentre 28 casos; 75\%), pós-injeção intravítrea (6 dentre 7 casos, 85,7\%), póstrauma ( 6 dentre 8 casos; 75\%) e pós-retirada de sutura (5 dentre 5 casos; $100 \%$ ). A positividade foi abaixo de $40 \%$ nas seguintes situações clínicas: casos crônicos de pósoperatório de cirurgia de catarata, pós-vitrectomia e pós-cirurgia de glaucoma. A menor positividade observada foi nos casos pós vitrectomia ( 1 dentre 7 casos; 14,3\%).

Nesta casuística, amostras de 14 pacientes foram coletadas após uso de antibiótico intravítreo com positividade em seis amostras (42,8\%). Nas demais 73 amostras, sem uso prévio de antibiótico, a positividade foi em 47 amostras $(54,0 \%)$ ( $p=0,131$, teste Qui-quadrado) (Tabelas 10 e 11).

Dentre as 48 amostras positivas para bactéria na cultura, convencional com ou sem Maldi direto, o $1^{\circ}$ procedimento foi biópsia vítrea em 32 pacientes e VVPP em 16 pacientes, acompanhado de IIV de antibióticos, e um paciente (caso 6) teve amostras de ambos os olhos. Dentre as biópsias vítreas como $1^{\circ}$ procedimento, três amostras não foram analisadas. Desta forma, a positividade na biópsia vítrea foi em 27 das 29 amostras $(93,1 \%)$ e na VVPP, como $1^{\circ}$ procedimento, foi em todas as 16 amostras $(100 \%)(p=0,531$, teste exato de Fisher) (Tabelas 10 e 11). Por outro lado, se consideramos todas as 71 amostras coletadas no $1^{\circ}$ procedimento, a positividade foi $56,2 \%$ (27 em 48 amostras) para biópsia vítrea e 69,6\% (16 em 23 amostras) para $\operatorname{VVPP}(\mathrm{p}=0,283$, teste Qui quadrado). (Tabelas 10, 12 e 13), 
Dentre os 13 pacientes com amostras coletadas e analisadas de biópsia e VVPP, a positividade em ambas as amostras foi em $6(46,1 \%)$, positividade somente na biópsia e negativa na VVPP em $5(38,4 \%)$ e positividade somente na VVPP $\left(2^{\circ}\right.$ procedimento) em $2(15,4 \%)$ (Tabela 12).

Foram analisados dez casos com amostras simultâneas não diluídas e diluídas (casos 4, 6, 9, 11, 20, 21, 23, 35, 41 e 45), sendo observada concordância de resultados em todos os casos. Ao analisar o tempo para identificação do microrganismo (turnaround time, TAT) dessas amostras, a média do TAT de amostras não diluídas foi $17,0 \pm 1,8$ e de amostras diluídas foi $18,0 \pm 1,7$ ( $\mathrm{p}=0,126$, teste Wilcoxon pareado) (Tabela 7).

Tabela 10 - Positividade na cultura e variáveis relativas à amostra ocular de pacientes com endoftalmite

\begin{tabular}{llll}
\hline \multicolumn{1}{c}{ Variáveis } & \multicolumn{1}{c}{$\begin{array}{c}\text { Condições } \\
\text { analisadas }\end{array}$} & Positividade & \multicolumn{1}{c}{ p } \\
\hline Antibiótico & Sim $(\mathrm{n}=14)$ & $42,8 \%$ & $0,131^{\mathrm{b}}$ \\
& Não $(\mathrm{n}=73)$ & $64,3 \%$ & \\
Amostras positivas $^{\mathrm{a}}{ }^{\mathrm{a}}$ & Biópsia $(\mathrm{n}=32)$ & $93,1 \%$ & \\
& Vitrectomia $(\mathrm{n}=16)$ & $100 \%$ & $0,531^{\mathrm{c}}$ \\
Todas amostras $^{\mathrm{a}}$ & Biópsia $(\mathrm{n}=48)$ & $56,2 \%$ & $0,283^{\mathrm{b}}$ \\
& Vitrectomia $(\mathrm{n}=23)$ & $69,6 \%$ & \\
\hline
\end{tabular}

${ }^{a}$ considerando-se o $1{ }^{o}$ procedimento; ${ }^{b}$ teste Qui-quadrado; ${ }^{c}$ teste exato de Fisher 
Tabela 11 - Positividade nas culturas de material ocular dos 87 pacientes com suspeita de endoftalmite, de acordo com a fonte de infecção

\begin{tabular}{|c|c|c|c|c|c|}
\hline Fonte de infecção & $\mathbf{n}$ & Positivo & $\%$ & Negativo & $\%$ \\
\hline $\begin{array}{l}\text { Facoemulsificação/ facectomia } \\
\text { extracapsular }\end{array}$ & 31 & 22 & 71,0 & 9 & 29,0 \\
\hline Aguda & 28 & 21 & 75,0 & 7 & 25,0 \\
\hline com antibiótico & & 4 & & 1 & \\
\hline sem antibiótico & & 17 & & 6 & \\
\hline Crônica & 3 & 1 & 33,3 & 2 & 66,7 \\
\hline com antibiótico & & 0 & & 0 & \\
\hline sem antibiótico & & 1 & & 2 & \\
\hline Vitrectomia & 7 & 1 & 14,3 & 6 & 85,7 \\
\hline Aguda & 4 & 1 & 25,0 & 3 & 75,0 \\
\hline com antibiótico & & 0 & & 1 & \\
\hline sem antibiótico & & 1 & & 2 & \\
\hline Crônica & 3 & 0 & 0,0 & 3 & 100,0 \\
\hline com antibiótico & & 0 & & 1 & \\
\hline sem antibiótico & & 0 & & 2 & \\
\hline Injeção intravítrea & 7 & 6 & 85,7 & 1 & 14,3 \\
\hline com antibiótico & & 0 & & 0 & \\
\hline sem antibiótico & & 6 & & 1 & \\
\hline Cirurgia de glaucoma & 19 & 7 & 36,8 & 12 & 63,2 \\
\hline Manifestação precoce & 9 & 3 & 33,3 & 6 & 66,7 \\
\hline com antibiótico & & 0 & & 3 & \\
\hline sem antibiótico & & 3 & & 3 & \\
\hline Manifestação tardia & 10 & 4 & 40,0 & 6 & 60,0 \\
\hline com antibiótico & & 0 & & 0 & \\
\hline sem antibiótico & & 4 & & 6 & \\
\hline Trauma & 8 & 6 & 75,0 & 2 & 25,0 \\
\hline com antibiótico & & 1 & & 0 & \\
\hline sem antibiótico & & 5 & & 2 & \\
\hline Retirada ponto & 5 & 5 & 100,0 & 0 & 0,0 \\
\hline com antibiótico & & 0 & & 0 & \\
\hline sem antibiótico & & 5 & & 0 & \\
\hline Endógena & 10 & 6 & 60,0 & 4 & 40,0 \\
\hline com antibiótico ${ }^{a}$ & & 1 & & 2 & \\
\hline sem antibiótico & & 5 & & 2 & \\
\hline
\end{tabular}

${ }^{\text {a }}$ casos nos quais foi considerado o uso sistêmico de antibiótico, além do intravítreo 
Tabela 12 - Prognóstico visual de 48 pacientes com endoftalmite bacteriana confirmada pela análise do material intraocular (cultura convencional com ou sem EM MALDI-TOF direto), de acordo com o patógeno identificado

\begin{tabular}{|c|c|c|c|c|c|c|c|c|}
\hline \multirow[b]{2}{*}{ Caso } & \multirow[b]{2}{*}{ Agente $^{\mathrm{b}}$} & \multirow[b]{2}{*}{ Fonte da infecção } & \multirow{2}{*}{$\begin{array}{l}\text { Procedimento } \\
\text { inicial }\end{array}$} & \multirow{2}{*}{$\begin{array}{l}\text { Segunda } \\
\text { intervenção }\end{array}$} & \multicolumn{3}{|c|}{ Acuidade visual } & \multirow{2}{*}{$\begin{array}{l}\text { Serviço de } \\
\text { origem }\end{array}$} \\
\hline & & & & & Pré op ${ }^{\mathrm{e}}$ & $\begin{array}{l}\text { na } \\
\text { apresentação }\end{array}$ & 3 meses & \\
\hline & Gram positivos & & & & & & & \\
\hline 9 & S. epidermidis & Facectomia extracapsular & $\operatorname{IIV}(+)^{\mathrm{c}}$ & $\operatorname{VVPP}(+)^{\mathrm{c}}$ & MM & PL & $20 / 60$ & SUS \\
\hline 12 & S. epidermidis & Facoemulsificação & IIV & - & $20 / 60$ & MM & $20 / 25$ & SUS \\
\hline 13 & S. epidermidis & Facoemulsificação & IIV & - & $20 / 50$ & MM & $20 / 200$ & Convenio \\
\hline 19 & S. epidermidis & Facoemulsificação & $\operatorname{IIV}(-)$ & $\operatorname{VVPP}(+)$ & $20 / 40$ & MM & $20 / 200$ & Convenio \\
\hline 20 & S. epidermidis & Facoemulsificação & $\operatorname{IIV}(+)$ & $\operatorname{VVPP}(+)$ & $20 / 60$ & MM & $20 / 30$ & SUS \\
\hline 15 & S. epidermidis & Facoemulsificação & VVPP & - & NI & PL & $20 / 60$ & Convenio \\
\hline 16 & S. epidermidis & Facoemulsificação & VVPP & - & NI & MM & $20 / 25$ & Convenio \\
\hline 17 & S. epidermidis & Facoemulsificação & VVPP & - & $20 / 400$ & MM & $20 / 30$ & Convenio \\
\hline 18 & S. epidermidis & Facoemulsificação & VVPP & - & $20 / 60$ & MM & $20 / 50$ & Convenio \\
\hline 8 & S. epidermidis & $\begin{array}{l}\text { Injeção intravítrea de } \\
\text { bevacizumabe }\end{array}$ & $\operatorname{IIV}(+)$ & VVPP (-) & $\mathrm{CD} 1 \mathrm{~m}$ & MM & MM & SUS \\
\hline $\begin{array}{l}\text { sem } \\
\text { maldi }\end{array}$ & S. epidermidis & $\begin{array}{l}\text { Injeção intravítrea de } \\
\text { bevacizumabe }\end{array}$ & $\operatorname{IIV}(+)$ & VVPP $^{d}$ & $20 / 200$ & MM & $20 / 200$ & SUS \\
\hline 7 & S. epidermidis & $\begin{array}{l}\text { Injeção intravítrea de } \\
\text { triancinolona }\end{array}$ & $\operatorname{IIV}(+)$ & VVPP (-) & $20 / 100$ & PL & $20 / 80$ & SUS \\
\hline 10 & S. epidermidis & Remoção de sutura & IIV & - & $20 / 20$ & PL & $20 / 20$ & SUS \\
\hline 14 & S. epidermidis & Remoção de sutura & IIV & - & $20 / 80$ & MM & $20 / 40$ & SUS \\
\hline 11 & S. epidermidis & Vitrectomia & VVPP & - & $20 / 200$ & MM & MM & SUS \\
\hline
\end{tabular}


Tabela 12 (cont). Prognóstico visual de 48 pacientes com endoftalmite bacteriana confirmada pela análise do material intraocular (cultura convencional com ou sem EM MALDI-TOF direto), de acordo com o patógeno identificado

\begin{tabular}{|c|c|c|c|c|c|c|c|c|}
\hline \multirow[b]{2}{*}{ Caso } & \multirow[b]{2}{*}{ Agente $^{b}$} & \multirow[b]{2}{*}{ Fonte da infecção } & \multirow{2}{*}{$\begin{array}{l}\text { Procedimento } \\
\text { inicial }\end{array}$} & \multirow{2}{*}{$\begin{array}{l}\text { Segunda } \\
\text { intervenção }\end{array}$} & \multicolumn{3}{|c|}{ Acuidade visual } & \multirow{2}{*}{$\begin{array}{l}\text { Serviço de } \\
\text { origem }\end{array}$} \\
\hline & & & & & Pré op ${ }^{\mathrm{e}}$ & $\begin{array}{l}\text { na } \\
\text { apresentação }\end{array}$ & 3 meses & \\
\hline 1 & S. aureus & Endógena & Evisceração & - & NI & SPL & Evisceração & SUS \\
\hline 2 & S. aureus & Trauma & $\operatorname{IIV}^{\mathrm{d}}$ & $\operatorname{VVPP}(+)$ & NI & PL & PL & SUS \\
\hline 3 & S. aureus & Facoemulsificação & IIV(-) & $\operatorname{VVPP}(+)$ & NI & PL & PL & SUS \\
\hline 4 & S. aureus & Endógena & VVPP & - & $20 / 200$ & $\mathrm{MM}$ & CD 1.5 & Convenio \\
\hline 5 & S. aureus & $\begin{array}{l}\text { Injeção intravítrea de } \\
\text { bevacizumabe }\end{array}$ & VVPP & - & $\mathrm{CD} 2 \mathrm{~m}$ & $\mathrm{MM}$ & $\mathrm{CD} 2 \mathrm{~m}$ & Convenio \\
\hline \multirow[t]{2}{*}{6} & S. aureus & Endógena & IIV OD & Evisceração $^{d}$ & $20 / 30$ & MM & Evisceração & Convenio \\
\hline & & & VVPP OE & - & $20 / 30$ & MM & $\mathrm{MM}$ & \\
\hline 21 & S. haemolyticus & $\begin{array}{l}\text { Injeção intravítrea de } \\
\text { ranibizumabe }\end{array}$ & VVPP & - & $20 / 80$ & $\mathrm{MM}$ & $\mathrm{CD} 0,5 \mathrm{~m}$ & Convenio \\
\hline 22 & S. haemolyticus & Facoemulsificação & $\operatorname{VVPP}(+)$ & $\operatorname{VVPP}^{\mathrm{d}}$ & NI & MM & $20 / 80$ & \\
\hline 23 & S. lugdunensis & Facoemulsificação & VVPP & - & $20 / 60$ & $\mathrm{MM}$ & $20 / 20$ & SUS \\
\hline 24 & S. lugdunensis & $\begin{array}{l}\text { Injeção intravítrea de } \\
\text { bevacizumabe }\end{array}$ & $\operatorname{IIV}(+)$ & VVPP $^{d}$ & $\mathrm{CD} 5 \mathrm{~cm}$ & MM & $\mathrm{CD} 5 \mathrm{~cm}$ & Convenio \\
\hline 25 & S. saprophyticus & Trauma & VVPP & - & $\mathrm{CD} 3 \mathrm{~m}$ & $\mathrm{MM}$ & MM & Convenio \\
\hline 26 & S. pneumoniae & Facoemulsificação & IIV & - & $\mathrm{NI}$ & $\mathrm{PL}$ & PL & SUS \\
\hline 27 & S. pneumoniae & Remoção de sutura & IIV & - & $\mathrm{CD} 2 \mathrm{M}$ & PL & PL & Convenio \\
\hline 28 & S. pneumoniae & Remoção de sutura & $\operatorname{IIV}(+)$ & VVPP $^{d}$ & $20 / 50$ & PL & MM & SUS \\
\hline 29 & S. pneumoniae & Remoção de sutura & $\operatorname{IIV}(+)$ & VVPP (-) & $20 / 20$ & PL & MM & SUS \\
\hline 30 & S. pneumoniae & Trabeculectomia & $\operatorname{IIV}(+)$ & VVPP (-) & NI & PL & SPL & SUS \\
\hline
\end{tabular}


Tabela 12 (cont). Prognóstico visual de 48 pacientes com endoftalmite bacteriana confirmada pela análise do material intraocular (cultura convencional com ou sem EM MALDI-TOF direto), de acordo com o patógeno identificado

\begin{tabular}{|c|c|c|c|c|c|c|c|c|}
\hline \multirow[b]{2}{*}{ Caso } & \multirow[b]{2}{*}{ Agente $^{b}$} & \multirow[b]{2}{*}{ Fonte da infecção } & \multirow{2}{*}{$\begin{array}{l}\text { Procedimento } \\
\text { inicial }\end{array}$} & \multirow{2}{*}{$\begin{array}{l}\text { Segunda } \\
\text { intervenção }\end{array}$} & \multicolumn{3}{|c|}{ Acuidade visual } & \multirow{2}{*}{$\begin{array}{l}\text { Serviço d } \\
\text { origem }\end{array}$} \\
\hline & & & & & Pré op ${ }^{\mathrm{e}}$ & $\begin{array}{l}\text { na } \\
\text { apresentação }\end{array}$ & 3 meses & \\
\hline 31 & S. pneumoniae & Facectomia extracapsular & IIV $(+)$ & VVPP (-) & MM & PL & SPL & SUS \\
\hline 32 & S. pneumoniae & Trabeculectomia & $\operatorname{IIV}(+)$ & VVPP (+) & NI & MM & PL & SUS \\
\hline 33 & S. pneumoniae & Trabeculectomia & IIV $(+)$ & $\operatorname{VVPP}(+)$ & $20 / 70$ & MM & PL & SUS \\
\hline 34 & S. pneumoniae & Implante de tubo & $\operatorname{IIV}(+)$ & VVPP (+) & $20 / 100$ & PL & SPL & SUS \\
\hline 35 & $\begin{array}{l}\text { Streptococcus grupo } \\
\text { viridans }\end{array}$ & Trauma & $\operatorname{IIV}(+)$ & VVPP (+) & NI & PL & SPL & SUS \\
\hline 36 & $\begin{array}{l}\text { Streptococcus grupo } \\
\text { viridans }\end{array}$ & Trauma & IIV & - & NI & MM & $20 / 200$ & SUS \\
\hline 37 & $\begin{array}{l}\text { Streptococcus grupo } \\
\text { viridans }\end{array}$ & Facoemulsificação & IIV & - & $20 / 40$ & SPL & SPL & Convenio \\
\hline 38 & $\begin{array}{l}\text { Streptococcus grupo } \\
\text { viridans }\end{array}$ & Trabeculectomia & IIV & - & $\mathrm{NI}$ & MM & $20 / 200$ & SUS \\
\hline 39 & Abiotrophia & Facoemulsificação & VVPP & - & $20 / 200$ & PL & $\mathrm{CD} 3 \mathrm{~m}$ & Convenio \\
\hline 40 & Abiotrophia & Facoemulsificação & VVPP & - & $20 / 80$ & MM & $\mathrm{CD} 3 \mathrm{~m}$ & Convenio \\
\hline 41 & Bacillus sp & Facoemulsificação & VVPP & - & $\mathrm{NI}$ & PL & PL & SUS \\
\hline 42 & Bacillus sp & Facectomia extracapsular & IIV & - & $\mathrm{CD} 2 \mathrm{~m}$ & MM & SPL & SUS \\
\hline 43 & E. faecalis & Facoemulsificação & VVPP & - & $20 / 100$ & SPL & SPL & $\begin{array}{r}\text { Convenio } \\
\text { con }\end{array}$ \\
\hline
\end{tabular}


Tabela 12 (conclusão). Prognóstico visual de 48 pacientes com endoftalmite bacteriana confirmada pela análise do material intraocular (cultura convencional com ou sem EM MALDI-TOF direto) de acordo com o patógeno identificado

\begin{tabular}{|c|c|c|c|c|c|c|c|c|}
\hline \multirow[b]{2}{*}{ Caso } & \multirow[b]{2}{*}{ Agente $^{\mathrm{b}}$} & \multirow[b]{2}{*}{ Fonte da infecção } & \multirow{2}{*}{$\begin{array}{l}\text { Procedimento } \\
\text { inicial }\end{array}$} & \multirow{2}{*}{$\begin{array}{l}\text { Segunda } \\
\text { intervenção }\end{array}$} & \multicolumn{3}{|c|}{ Acuidade visual } & \multirow{2}{*}{$\begin{array}{l}\text { Serviço de } \\
\text { origem }\end{array}$} \\
\hline & & & & & Pré op ${ }^{e}$ & $\begin{array}{l}\text { na } \\
\text { apresentação }\end{array}$ & 3 meses & \\
\hline 44 & $\begin{array}{l}\text { Gram negativos } \\
\text { H. influenzae }\end{array}$ & Trabeculectomia & $\mathrm{IIV}^{\mathrm{db}}$ & VVPP(+) & NI & PL & SPL & SUS \\
\hline 45 & P. aeruginosa & Facoemulsificação & IIV $^{d}$ & VVPP(+) & NI & MM & MM & SUS \\
\hline 46 & S. marcencens & Trauma & IIV & - & NI & PL & SPL & SUS \\
\hline 47 & S. marcencens & Implante de tubo & IIV & Evisceração & NI & SPL & Evisceração & SUS \\
\hline
\end{tabular}

a número refere-se ao da Tabela 6; b $S$. aureus, S. spidermidis, $S$ haemolyticus, S. lugdunensis, S.saprophyticus=Staphylococcus; $\mathrm{VGS=Streptococcus} \mathrm{do} \mathrm{grupo} \mathrm{viridans;} S$ pneumoniae $=$ Streptococcus; H. influenzae $=$ Haemophilus; P.aeruginosa $=$ Pseudomonas; E.faecalis $=$ Enterococco; S.marcencens $=$ Serratia $;{ }^{\mathrm{c}}$ nos casos com ambas as amostras testadas, tanto do procedimento inicial como $2^{\circ}$ procedimento, positividade ou negatividade está escrita entre parênteses; ${ }^{\mathrm{d}}$ não colhido; ${ }^{\mathrm{e}}$ acuidade visual no pré operatório

VVPP=vitrectomia; IIV= injeção intravítrea de antibiótico; $\mathrm{NI}=$ não informado; $\mathrm{CD}=$ conta-dedos; $\mathrm{MM}=$ movimento de mãos;

$\mathrm{PL}=$ percepção luminosa; $\mathrm{SPL}=$ sem percepção luminosa; SUS= Sistema Único de Saúde 
Em relação ao prognóstico visual (Tabela 12), dentre os 15 casos com cultura positiva para Staphylococcus epidermidis, em nove casos (60\%) e em 13 (86,7\%) a acuidade visual no $3^{\circ}$ mês de seguimento foi melhor ou igual a 20/60 e melhor ou igual a 20/200, respectivamente. Considerando os 11 casos pós-cirurgia de catarata com acuidade visual melhor ou igual a 20/200, nove $(81,8 \%)$ foram associados à infecção pelo $S$. epidermidis. Em contrapartida, dentre os 33 casos com cultura positiva para outras bactérias Gram-positivas e bactérias Gram-negativas, observou-se acuidade visual melhor ou igual a 20/200 em somente quatro casos $(12,1 \%)(p<0,001$, teste de Fisher).

Trinta e quatro pacientes com suspeita de endoftalmite infecciosa tiveram cultura das amostras oculares negativa. Como demonstrado nos dados da Tabela 11, a percentagem de casos com cultura negativa foi maior que $60 \%$ naqueles casos associados às endoftalmites crônicas pós-cirurgia de catarata, às vitrectomias e às cirurgias de glaucoma. Nos dados da Tabela 13, estão representados os casos com cultura negativa.

Nos dados da Tabela 14, observa-se a sensibilidade ao antimicrobiano dos patógenos isolados com base no TSA estabelecido no HCFMUSP. Existe uma resistência do Staphylococcus epidermidis e Staphylococcus haemolyticus a ciprofloxacino, moxifloxacino e oxacilina. Todas as amostras testadas foram sensíveis a vancomicina e ceftazidima. 
Tabela 13 - Características clínicas dos 34 pacientes com suspeita de endoftalmite e análise negativa na microbiologia

\begin{tabular}{|c|c|c|c|c|c|}
\hline \multirow{2}{*}{ Fonte da Infecção } & \multirow{2}{*}{ Tempo atéendoftalmite } & \multirow{2}{*}{ Procedimento inicial } & \multirow{2}{*}{$2^{\mathrm{a}}$ intervenção } & \multicolumn{2}{|c|}{ Acuidade visual } \\
\hline & & & & na apresentação & 3 meses \\
\hline Facectomia extracapsular & 7 dias & IIV & NR & PL & SPL \\
\hline Facectomia extracapsular & 10 dias & $\operatorname{IIV}(-)$ & VVPP(-) & MM & SPL \\
\hline Facoemulsificação & 4 dias & Evisceração & NR & SPL & Evisceração \\
\hline Facoemulsificação & 11 dias & IIV(-) & VVPP $^{b}$ & MM & $\mathrm{CD} 0,5 \mathrm{~m}$ \\
\hline Facoemulsificação & 5 dias & VVPP & NR & MM & $\mathrm{CD} 2 \mathrm{~m}$ \\
\hline Facoemulsificação & 2 dias & VVPP & NR & MM & SPL \\
\hline Facoemulsificação & 21 dias & IIV & NR & $\mathrm{CD} 1 \mathrm{~m}$ & $20 / 25$ \\
\hline Facectomia extracapsular & 2 meses & $\operatorname{IIV}(-)$ & $\operatorname{IIV}(-)$ & MM & MM \\
\hline Facoemulsificação & 2 meses & IIV & NR & MM & $\mathrm{CD} 2 \mathrm{M}$ \\
\hline Vitrectomia & 35 dias & Evisceração & NR & SPL & SPL \\
\hline Vitrectomia & 7 dias & VVPP & NR & MM & $20 / 200$ \\
\hline Vitrectomia & 2 meses & IIV & NR & MM & MM \\
\hline Vitrectomia & 25 dias & IIV $^{b}$ & VVPP (-) & MM & $20 / 200$ \\
\hline Vitrectomia & 3 meses & IIV & Evisceração $^{b}$ & PL & evi \\
\hline Vitrectomia & 60 dias & IIV & NR & MM & $20 / 80$ \\
\hline Injeção intravítrea de gás & & $\operatorname{IIV}(-)$ & $\operatorname{VVPP}(-)$ & MM & $20 / 60$ \\
\hline Trabeculectomia(blebite) & 12 meses & VVPP & NR & MM & $20 / 60$ \\
\hline Trabeculectomia & 30 dias & VVPP & NR & PL & PL \\
\hline Trabeculectomia & 8 anos & $\operatorname{IIV}(-)$ & VVPP(-) & PL & $20 / 50$ \\
\hline Trabeculectomia & 30 dias & IIV(-) & VVPP(-) & PL & PL \\
\hline
\end{tabular}


Tabela 13 (cont). Características clínicas dos 34 pacientes com suspeita de endoftalmite e análise negativa na microbiologia

\begin{tabular}{|c|c|c|c|c|c|}
\hline \multirow{2}{*}{ Fonte da Infecção } & \multirow{2}{*}{ Tempo atéendoftalmite } & \multirow{2}{*}{ Procedimento inicial } & \multirow{2}{*}{$2^{\mathrm{a}}$ intervenção } & \multicolumn{2}{|c|}{ Acuidade visual } \\
\hline & & & & na apresentação & 3 meses \\
\hline Trabeculectomia & 30 dias & IIV $^{\mathrm{b}}$ & VVPP(-) & PL & $\mathrm{CD} 2 \mathrm{~m}$ \\
\hline Trabeculectomia & 12 meses & IIV & NR & PL & SPL \\
\hline Trabeculectomia & 30 dias & $\operatorname{IIV}(-)$ & VVPP (-) & MM & SPL \\
\hline Trabeculectomia & 2 meses & IIV & NR & MM & $20 / 20$ \\
\hline Implante de tubo & 3 meses & IIV & NR & MM & MM \\
\hline Implante de tubo & 5 dias & VVPP & NR & MM & $20 / 50$ \\
\hline Agulhamento & 30 dias & IIV $^{\mathrm{b}}$ & VVPP (-) & PL & SPL \\
\hline Implante de Tubo & 3 meses & IIV & NR & PL & MM \\
\hline Trauma & & VVPP & NR & MM & PL \\
\hline Trauma & & IIV $^{b}$ & VVPP(-) & MM & PL \\
\hline Endógena & & $\operatorname{IIV}(-)$ & $\operatorname{IIV}(-)$ & SPL & Evisceração \\
\hline Endógena & & $\operatorname{IIV}(-)$ & IIV $^{\mathrm{b}}$ & MM & MM \\
\hline Endógena & & $\operatorname{IIV}(-)$ & VVPP(-) & MM & $20 / 40$ \\
\hline Endógena & & $\operatorname{IIV}(-)$ & IIV $^{\mathrm{b}}$ & MM & MM \\
\hline
\end{tabular}

${ }^{\text {a }}$ S. mitis $=$ Streptococcus. ${ }^{\mathrm{b}}$ não colhido

$\mathrm{VVPP}=$ vitrectomia;IIV= injeção intravítrea de antibiótico; $\mathrm{NR}=$ não realizado; $\mathrm{CD}=$ conta-dedos; $\mathrm{MM}=$ movimento de mãos;

$\mathrm{PL}=$ percepção luminosa; $\mathrm{SPL}=$ sem percepção luminosa; $\mathrm{SUS}=$ Sistema Único de Saúde 
Tabela 14 - Susceptibilidade aos antibióticos dos patógenos isolados nas 44 amostras oculares com cultura positiva para bacterias Gram positiva ou Gram negativa de pacientes com suspeita de endoftalmite

\begin{tabular}{|c|c|c|c|c|c|c|c|c|c|}
\hline Agentes isolados & $\mathrm{N}^{\mathrm{a}}$ & $\begin{array}{l}\text { Gentamicina/ } \\
\text { Tobramicina }\end{array}$ & Ciprofloxacino & $\begin{array}{c}\text { Moxifloxacino/ } \\
\text { Levofloxacino/ } \\
\text { Ofloxacino }\end{array}$ & Linezolida & Vancomicina & Ceftazidima & Amicacina & $\begin{array}{l}\text { Oxacilina/ } \\
\text { Cefuroxima/ } \\
\text { Cefazolina }\end{array}$ \\
\hline \multicolumn{10}{|l|}{ Gram positivo } \\
\hline S. epidermidis & 14 & $79 \%$ & $7 \%$ & $7 \%$ & $100 \%$ & $100 \%$ & $*$ & $*$ & $21 \%$ \\
\hline S. aureus & 7 & $100 \%$ & $100 \%$ & $100 \%$ & $100 \%$ & $100 \%$ & $*$ & * & $100 \%$ \\
\hline S. haemolyticus & 2 & $100 \%$ & $0 \%$ & $0 \%$ & $100 \%$ & $100 \%$ & $*$ & $*$ & $50 \%$ \\
\hline S. lugdunensis & 2 & $100 \%$ & $100 \%$ & $100 \%$ & $100 \%$ & $100 \%$ & $*$ & $*$ & $100 \%$ \\
\hline S. saprophyticus & 1 & $100 \%$ & $100 \%$ & $100 \%$ & $100 \%$ & $100 \%$ & $*$ & $*$ & $0 \%$ \\
\hline S. pneumoniae & $8 * *$ & $*$ & $*$ & $100 \%$ & $*$ & $100 \%$ & $*$ & $*$ & $*$ \\
\hline S. grupo viridans & 4 & $*$ & $*$ & $*$ & $*$ & $100 \%$ & $*$ & $*$ & $*$ \\
\hline E. faecalis & 1 & $100 \%$ & $*$ & $*$ & $100 \%$ & $100 \%$ & $*$ & $*$ & $*$ \\
\hline \multicolumn{10}{|l|}{ Gram negativo } \\
\hline P.aeruginosa & 1 & $100 \%$ & $100 \%$ & $*$ & $*$ & $*$ & $100 \%$ & $100 \%$ & $*$ \\
\hline H. influenzae & 1 & $*$ & $100 \%$ & $*$ & $*$ & $*$ & $*$ & $*$ & $*$ \\
\hline S. marcencens & 2 & $100 \%$ & $100 \%$ & $*$ & $*$ & $*$ & $100 \%$ & $100 \%$ & $*$ \\
\hline E.cloacae & 1 & $100 \%$ & $100 \%$ & $*$ & $*$ & $*$ & $100 \%$ & $100 \%$ & $*$ \\
\hline
\end{tabular}

a S. aureus, S. spidermidis, $S$ haemolyticus, S. lugdunensis, S. saprophyticus=Staphylococcus; $\mathrm{VGS=Streptococcus} \mathrm{do} \mathrm{grupo} \mathrm{viridans;} \mathrm{S.} \mathrm{pneumoniae}=$ Streptococcus; H. influenzae= Haemophilus; P. aeruginosa $=$ Pseudomonas $;$ E. faecalis $=$ Enterococco $;$ S. marcencens $=$ Serratia $;$ E. cloacae $=$ Enterobacteria

aúmero de amostras positivas * não testado

** havia nove pacientes, e em um deles não foi realizado teste de sensibilidade 
6 Discussão 


\section{DISCUSSÃO}

As endoftalmites infecciosas apresentam prognóstico visual reservado em grande parte dos casos ${ }^{(125)}$. O diagnóstico clínico precoce é essencial e pode auxiliar para um melhor prognóstico visual; o diagnóstico etiológico preciso e rápido das endoftalmites infecciosas permite um tratamento mais adequado ${ }^{(9,126)}$. O presente estudo prospectivo, incluindo amostras de humor vítreo de 87 pacientes com suspeita de endoftalmite, no período entre 2015 e 2017, avaliou a identificação do agente etiológico pela análise direta do humor vítreo inoculado em frasco de hemocultura infantil com a espectrometria de massas MALDI-TOF. Foram analisados fatores relacionados à amostra e características clínicas, de acordo com o isolado na amostra.

\subsection{Métodos para identificação do agente etiológico}

Há vários métodos para identificação do agente etiológico das endoftalmites, como exposto em outra sessão (página 12, seção 3.6). No entanto, a cultura é ainda a técnica padronizada na maioria dos centros de Oftalmologia, nos quais técnicas de PCR não estão disponíveis na rotina diagnóstica das endoftalmites. Desta forma, o presente estudo avaliou o uso da EM MALDI-TOF diretamente em amostras vítreas inoculadas em frasco de hemocultura infantil com o principal objetivo de otimização na obtenção dos resultados.

Todas as amostras oculares de endoftalmite foram inoculadas em frascos de hemocultura infantil, quer seja imediatamente após a coleta, quer seja após o fracionamento do material inicial coletado. Na suspeita de infecção por fungos, anaeróbios e/ou micobactéria, outros frascos ou meios foram também usados.

Em estudo retrospectivo, nosso grupo avaliou o uso do frasco de hemocultura e a semeadura em meios sólidos/líquidos nas endoftalmites ${ }^{(14)}$. Foram analisadas 20 amostras pela cultura convencional, no período entre 2010 e 2011, com positividade de $35 \%$, e 34 amostras com uso de frasco de hemocultura infantil, no período entre 
2012 e 2015, com melhora da positividade para $64,7 \%{ }^{(14)}$. Em outro estudo realizado também em nosso Serviço, sem uso de frasco de hemocultura, a positividade da cultura foi $41,7 \%{ }^{(127)}$. Diante destes resultados prévios de nosso Serviço, com os dados da literatura, no presente estudo, a cultura convencional foi feita, usando o frasco de hemocultura infantil e não utilizando a semeadura diretamente nos meios sólidos. Assim, nos casos de endoftalmite aguda pós-operatória, a alta positividade de $75 \%$ com o uso do frasco de hemocultura infantil reforça a possibilidade de se usar o frasco como único meio para inoculação nos casos suspeitos de microrganismos aeróbios.

(Tabela 11) Esta orientação é relevante nas biópsias vítreas quando a amostra coletada tem pequeno volume.

Além das bactérias aeróbias, foi possível identificar três casos de endoftalmite por Candida albicans com uso do frasco de hemocultura infantil; estes casos também foram identificados tanto na cultura em meio específico para fungo (frasco Myco/F) como pelo frasco de hemocultura aeróbio infantil. Como nas vitrectomias, a quantidade de material do cassete é maior, optou-se por utilizar os meios aeróbios, anaeróbios e para fungo, para avaliar a positividade, nos casos de endoftalmite endógena. Embora fossem poucos casos, estes resultados reforçam a possibilidade de se usar isoladamente o frasco de hemocultura infantil, mesmo na suspeita fúngica.

A positividade de 33\% nos casos de endoftalmite crônica foi baixa indicando necessidade de otimização do método. Não foi possível identificar nenhum caso por Propionibacterium acne, pois possivelmente a baixa virulência e o pequeno número de microrganismos podem dificultar a identificação dos agentes anaeróbios ${ }^{(128)}$. O PCR, metagenômica e coleta do humor vítreo por meio de vitrectomia podem melhorar a detecção dos casos em que existe alta suspeita apesar de culturas negativas ${ }^{(6)}$.

Assim, a inoculação direta de amostra vítrea nos frascos de hemocultura é uma alternativa viável para amostras pequenas com alta sensibilidade se comparadas com a cultura convencional com inoculação em meios sólidos. Entretanto, a identificação do patógeno a partir do frasco de hemocultura requer subculturas em meio agar retardando o resultado final ${ }^{(129)}$. Neste sentido, a espectrometria de massa MALDITOF veio para revolucionar, permitindo uma identificação rápida e precisa do patógeno em laboratórios clínicos. A principal vantagem da tecnologia de EM 
MALDI-TOF sobre outras técnicas laboratoriais para identificação de microrganismos é a agilidade para obtenção dos resultados. O intervalo entre a confecção do depósito e a leitura final do isolado pode ser tão rápido como 30 minutos ${ }^{(16,17)}$. Os espectros de massa (EM) são obtidos e processados por softwares específicos. Na prática clínica, diversos laboratórios de Microbiologia em São Paulo já utilizam esta técnica para identificação do agente etiológico após a subcultura, com redução de custos com insumos e mão de obra.

Esta técnica de EM MALDI-TOF foi aplicada para identificação direta a partir do frasco de hemocultura inoculado com amostras vítreas, assim como vem sendo realizado com outros fluidos. A agilidade na identificação do patógeno reduz o tempo de uso de antibiótico de amplo espectro, refletindo na redução de morbidade ${ }^{(130)}$.

Nesta técnica de EM MALDI-TOF, a etapa de extração da proteína bacteriana é muito importante. O material vítreo difere do sangue pois no sangue estão presentes proteínas nas hemácias, nos leucócitos e no soro que interferem na análise com picos espectrais adicionais ${ }^{(100)}$. Em 2017, quando o presente estudo já estava em andamento, Mailhac et al. compararam quatro métodos de extração de proteína de bactérias (espécies de Staphylococcus coagulase-negativa de pacientes com endoftalmite pósoperatória aguda), dois curtos e dois longos, com ou sem dodecil sulfato de sódio (SDS, sodium dodecyl sulphate) ${ }^{(131)}$. Mailhac et al. inocularam frascos de hemocultura com a suspensão de bactéria e o limiar específico para identificação das bactérias no sobrenadante destas hemoculturas foi avaliado. O protocolo de extração longa, sem utilizar SDS para lisar o agente, foi mais eficiente identificando 43 das 45 (96\%) bactérias testadas.

No presente estudo, foi usado o método de extração simples in-house com três etapas, adaptado da descrição original de Pulcrano et al. ${ }^{(124)}$. Este é o primeiro estudo que avalia amostra vítrea de pacientes com endoftalmite por ambos os métodos, cultura convencional e identificação direta com EM MALDI-TOF, a partir do frasco de hemocultura infantil. Obteve-se identificação concordante, tanto em gênero como espécie, com o identificado na cultura convencional em $51(81,1 \%)$ das 61 amostras positivas. Para as 56 amostras Gram-positivas, a concordância foi em 45 amostras (80,4\%); para as seis amostras Gram-negativas, a concordância deu-se em todas as 
amostras. A dificuldade de identificação de bactéria Gram positiva pela EM MALDITOF vem sendo observada em outras amostras clínicas. A parede das bactérias Grampositivas possui múltiplas camadas de peptideoglicano, tornando estas bactérias mais resistentes à lise do que as bactérias Gram-negativas, sendo necessário etapas adicionais na extração proteica, como adição de ácido fórmico, lisostafina, lisosima, mutanolisina e proteinase $\mathrm{K}^{(129)}$.

Buchan et al. compararam a técnica da EM MALDI-TOF direto de frasco de hemocultura positiva com os métodos da rotina microbiológica e observaram redução do tempo de identificação (turnaround time) de bactérias Gram-positivas entre 23 e 83 horas e de bactérias Gram-negativas entre 34 e 51 h ${ }^{(86)}$. No presente estudo, foi observada, para bactérias Gram-positivas, uma redução média de 34 horas, ou 3,7 vezes, e, para bactérias Gram-negativas, uma redução média de 30 horas, ou 5,2 vezes (Tabela 7).

Agentes mais agressivos parecem ter identificação mais rápida, possivelmente, em razão da maior concentração das bactérias na amostra. Observou-se que, em casos de Streptococcus (S. pneumoniae e VGS), Bacillus e Serratia marcencens, com evolução mais agressiva, a identificação pelo EM MALDI-TOF foi tão rápida como 5 a 13 horas (Tabela 7). Enquanto em casos de Staphilococcus epidermidis e Abiotrophia, com possível evolução mais benigna, a identificação pela EM MALDITOF foi mais demorada entre 23 e 94 horas (Tabela 7). Em estudo de modelos animais, já foi demonstrada essa diferença no tempo de infecção, de acordo com a carga bacteriana. Callegan et al. mostraram o rápido crescimento da carga bacteriana nas primeiras 24 horas de infecção em modelos animais com S. aureus, E. faecalis e Bacillus cereus ${ }^{(132)}$; já Foster et al. demonstraram um crescimento mais lento para $S$. epidermidis ${ }^{(133)}$. Nossos resultados mostram correspondência em relação ao comportamento in vivo do crescimento bacteriano semelhante a modelos animais

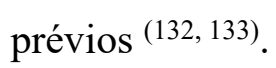

A quantidade de bactérias presentes na amostra deve influenciar na velocidade de identificação dos agentes. Nos casos de endoftalmite pós trauma (casos 2, 35, 36, 46), em que são agentes com agressividade maior e provável quantidade maior de inóculo, o tempo de identificação foi menor que 10 horas. 
O impacto do uso da EM MALDI-TOF em Microbiologia e, consequentemente, em programas de uso racional de antibióticos vem sendo difundido recentemente, levando à escolha adequada do antibiótico e otimização da antibioticoterapia com redução de taxa de mortalidade ${ }^{(90)}$. O mesmo impacto deve ser observado na Oftalmologia. A rápida identificação de agentes em menos de 24 horas permitirá ao oftalmologista avaliar se há resistência intrínseca ao antibiótico introduzido, e adaptar o antibiótico. Para patógenos com maior virulência, pode-se avaliar a necessidade de tratamento mais agressivo e precoce ou a necessidade de novos tratamentos para melhorar o prognóstico.

Dentre os pacientes com fungemia, em estudo realizado por Vaziri et al., a incidência de endoftalmite endógena foi $0,4 \%{ }^{(20)}$. A identificação de fungos por EM MALDI-TOF é uma revolução na micologia. As técnicas habituais podem exigir muitos dias para finalização. Observou-se nos três casos de endoftalmite fúngica com agente etiológico identificado redução do tempo em, pelo menos, 50\% para identificação da Candida albicans (Tabela 6). A agilidade e precisão da análise proteômica poderá em muitas ocasiões substituir a necessidade da utilização de métodos moleculares. A identificação do gênero Candida e também da espécie vêm sendo possível com os frascos de hemocultura aeróbio infantil ${ }^{(91,124,134)}$ e conseguiuse obter bons resultados no presente estudo, tanto pelo método convencional como com a análise direta com a EM MALDI-TOF, apenas com mudança simples na técnica de extração proteica. No entanto, para fungos filamentosos, há necessidade de adaptações no protocolo de extração. O banco de espectros de referência também deve ser adequado, quando a suspeita for fungos ${ }^{(134)}$.

Apesar dos ganhos que poderão ser proporcionados pela EM MALDI-TOF à Oftalmologia, esta tecnologia ainda incipiente apresenta algumas limitações. Como mencionado anteriormente, 11 amostras positivas para bactérias Gram-positivas pela cultura convencional não foram detectadas pela EM MALDI-TOF. A análise direta das amostras sanguíneas de pacientes com bacteremia também mostram essa sensibilidade menor para bactérias Gram-positivas, provavelmente, devido à parede de peptideoglicanos dessas bactérias $(135,136)$. Assim adaptações na extração são necessárias. 
Nos casos das culturas polimicrobianas, a técnica da identificação direta faz o diagnóstico de apenas um dos agentes; sendo necessário aguardar o crescimento na placa para comprovar que não foi uma infecção polimicrobiana. Em amostras sanguíneas, essa mesma dificuldade encontra-se em diversos estudos (137-139). Possivelmente, a técnica identifica o espectro da bactéria mais abundante. Estudo com diferentes técnicas de extrações da matriz vêm sendo realizados para identificar mais precocemente que se trata de cultura polimicrobiana, além de definir padrões de espectros de massa que podem ter sobreposição e devem ser comparados com padrões de espectros diferentes das monomicrobianas ${ }^{(135)}$. Enquanto essa desvantagem não for solucionada, será necessário ainda aguardar o término da cultura convencional nos casos com suspeita de infecção polimicrobiana.

Os bancos de dados que contêm espectros de referência disponíveis precisam de atualizações constantes com inclusão de espécies que ainda não são representadas; algumas espécies filogeneticamente próximas podem ter perfis idênticos de EM e não serem diferenciadas ${ }^{(134)}$.

E, por fim, ainda há necessidade de cultivo em placas de ágar para realização de testes de suscetibilidade aos antimicrobianos. Jo et al. demonstraram resultados confiáveis, ao analisarem diretamente do frasco de hemocultura, não somente a identificação do agente direta pela EM MALDI-TOF, como também o teste de sensibilidade aos antimicrobianos (TSA) ${ }^{(140)}$ Avanços nesta tecnologia devem vir de encontro a estas limitações.

É importante ressaltar que, devido às limitações citadas, a identificação do agente pela análise direta do humor vítreo inoculado no frasco de hemocultura com EM MALDI-TOF ainda não substitui a cultura convencional, no entanto, é um método de simples implantação na rotina de um laboratório e de baixo custo, reduzindo significativamente o tempo do diagnóstico etiológico das endoftalmites.

\subsection{Aspectos relacionados à amostra ocular}


A eficiência e relevância do resultado microbiológico é dependente da quantidade e do tipo de amostra. Algumas variáveis foram abordadas: uso de filtro de membrana, amostra de biópsia ou de VVPP, amostra não diluída ou diluída, amostra com antibiótico. Como exposto na sessão de métodos (seção 4.3, página 29), a conduta inicial foi definida pela equipe do médico responsável pelo paciente, variando de acordo com a disponibilidade de recursos técnicos e humanos e de normas internas de cada Serviço. Desta forma, estas variáveis foram analisadas de forma retrospectiva com número limitado de amostras representando cada variável, não permitindo resultados significativos.

Em nossa casuística, 12 amostras vítreas foram analisadas com uso de filtro de membrana (Tabela 8). Todo processamento foi realizado por dois médicos oftalmologistas residentes. Foi utilizada membrana com poro de $0,22 \mu \mathrm{m}$ no lugar de $0,45 \mu \mathrm{m}$ por ter maior possibilidade de reter bactérias e fungos. As análises foram comparadas com os resultados obtidos usando frasco de hemocultura aeróbio (infantil) e anaeróbio (adulto) e frasco Myco/F. O uso do filtro não se mostrou vantajoso, em relação ao frasco de hemocultura, para uma melhor positividade dos resultados, diferentemente do que se encontra na literatura. Deve-se ponderar que o número de casos incluídos foi pequeno. Apenas um dos casos foi positivo na cultura realizada com filtro de membrana, sendo negativo nos frascos de hemocultura; esta positividade sugere ser em razão da contaminação, pois o manuseio do material foi inadequado e a clínica não era compatível com o agente detectado. Notou-se como encontrado na literatura, grande limitação do uso do filtro de membrana pela dificuldade de se obter os materiais necessários (filtro, membrana de acetato, bomba de vácuo) e de seu manuseio. $\mathrm{O}$ uso do filtro de membrana talvez possa ser mais útil na identificação de micobactérias ou fungos filamentosos ${ }^{(6)}$.

Quanto à positividade de culturas obtidas de biópsia ou VVPP, o EVS demonstrou não haver diferença entre eles ${ }^{(141)}$. Com base nas recomendações do EVS em 1995, definiu-se que a vitrectomia inicial seria indicada no paciente com acuidade visual de percepção luminosa e a biópsia vítrea em pacientes com acuidade visual de movimentos de mãos ou melhor ${ }^{(8)}$. Mas, duas décadas já se passaram, novas tecnologias foram incorporadas à cirurgia de vitrectomia, tornando-a mais segura, além de maior disponibilidade cirúrgica em relação à época em que o EVS foi 
elaborado. Altan et al. avaliaram o sucesso do tratamento inicial em 88 olhos observando que VVPP inicial é preferencial à vitrectomia como $2^{\circ}$ procedimento após uma injeção intraocular de antibiótico inicial em todos os casos ${ }^{(142)}$. No presente estudo, dentre as amostras positivas, a positividade foi semelhante para material obtido por biópsia vítrea (93\%) e o obtido por VVPP (100\%), ambos como $1^{\circ}$ procedimento. Em somente duas amostras coletadas inicialmente por biópsia vítrea com resultado negativo, o material obtido na VVPP como $2^{\circ}$ procedimento demonstrou o agente etiológico (Tabela 10).

Ainda em relação à realização inicial de biópsia vítrea ou de VVPP, a conduta foi definida pelo médico responsável pelo paciente. Nos pacientes tratados em serviço público (HCFMUSP), a conduta inicial foi injeção intravítrea em 82,3\% dos casos; em contrapartida em serviço externo de convênio, a conduta inicial foi VVPP em 69,2\% dos casos, talvez pelo maior acesso e disponibilidade da sala cirúrgica.

Quanto à positividade em amostras de vítreo não diluído e diluído, foram analisados resultados de 11 casos. Os agentes identificados foram concordantes em todas as amostras. A mediana do TAT de amostras não diluídas foi 17,03 $\pm 1,8$ e de amostras diluídas foi $18,05 \pm 1,7(\mathrm{p}=0,126)$. Desta forma, embora pequeno o tamanho da amostra, os dados atuais indicam que a análise do material diluído é válida. Assim, deve-se considerar o risco de iatrogenia na obtenção do material não diluído em contraponto ao maior risco de contaminação ao se coletar material do cassete. Estas mesmas observações foram descritas por Chiquet et al. ${ }^{(143)}$.

Quanto ao uso de antibiótico intravítreo, os estudos realizados na França. onde a maioria dos casos de endoftalmite são tratados inicialmente com injeção intravítrea de antibióticos, demonstraram uma sensibilidade na cultura de somente $6 \%{ }^{(143)}$. Em nossa casuística, todas as amostras coletadas após uma biópsia vítrea como $1^{\mathrm{o}}$ procedimento tiveram uma possível interferência do uso de antibiótico intravítreo, com uma positividade de 42,8\%; e, nas amostras sem uso prévio de antibiótico, a positividade foi $64,3 \%(p=0,131$, Tabela 10). O TAT foi menor nas amostras sem antibiótico prévio. No entanto, mesmo em casos com amostras de um $2^{\circ}$ procedimento, isto é, após uso de antibiótico, as culturas foram positivas em $61 \%$ (Tabela 12). Isso 
demonstra que apesar do uso de antibiótico, ainda havia microrganismos vivos, daí a importância de nova dose de antibiótico.

E, por fim, embora amostras vítreas proporcionem resultados de cultura mais confiáveis e precisos do que amostras de humor aquoso, se a porta de entrada for mais anterior, como nos casos de endoftalmite pós-cirurgia de glaucoma e pós-trauma, amostras de humor aquoso poderão ser relevantes em razão da maior quantidade de bactéria no segmento anterior. No presente estudo, humor aquoso foi coletado de três pacientes, e, em dois, o humor vítreo foi também coletado, com resultado positivo em ambas as amostras; no entanto, com tempo de identificação maior na amostra do humor aquoso. Em um paciente, o resultado foi positivo somente na amostra do humor aquoso, sendo um paciente com endoftalmite pós-implante de tubo.

Dessa forma, não encontrou-se diferença de positividade na cultura entre material de biópsia vítrea e VVPP como $1^{\mathrm{o}}$ procedimento, nem entre amostras com uso prévio de antibiótico e amostras sem uso prévio de antibiótico, e, nem entre material diluído e material não diluído. O pequeno número de casos para cada variável testada pode ter limitado os resultados. No entanto, o estudo sugere que as amostras "não ideais" devem ser coletadas e encaminhadas para análise, pois um resultado positivo poderá influenciar a condução do caso.

\subsection{Aspectos relacionados à fonte de infecção}

$\mathrm{Na}$ literatura, há, aproximadamente, $80 \%$ das endoftalmites relacionadas a procedimentos cirúrgicos e entre $5 \%$ e $15 \%$ das endoftalmites são endógenas ${ }^{(23)}$. Em nossa casuística, $78 \%$ foram pós-operatórias, 10\% pós-traumas e 11,5\% endógenas. Dentre os 31 casos associados à cirurgia de catarata, nove foram encaminhados de um mesmo serviço externo. Foi possível calcular a incidência de endoftalmite neste serviço externo no período do estudo (entre outubro de 2015 e maio de 2017), sendo nove casos de endoftalmite após cirurgia de catarata em um total de 22.147 cirurgias $(0,04 \%)$. Em nosso serviço, a incidência de endoftalmite após cirurgia de catarata no período entre 2010 a 2018 foi de 49 casos, dentre 36.874 cirurgias (0,13\%). A positividade na cultura nas 31 amostras no período de nosso estudo (2015 e 2017) foi 
$75 \%$ nos casos agudos pós-cirurgia de catarata, entre os nove casos de serviço externo esta positividade foi ainda maior, $89 \%$. Condutas distintas para um paciente com endoftalmite no serviço público e em serviço de convênios podem explicar esta melhor positividade. A positividade pós-injeção intravítrea, pós-trauma e pós-retirada de ponto também foi acima de 70\%, reforçando a eficiência do uso de frasco de hemocultura infantil, da forma de coleta e encaminhamento do material. No entanto, em outras situações clínicas, a positividade foi abaixo de $40 \%$, a saber, pós-vitrectomia e pós-cirurgia de glaucoma.

A incidência de endoftalmite pós-cirurgia de catarata vem diminuindo pelas mudanças nas técnicas cirúrgicas, procedimento de esterilização e um melhor entendimento dos fatores de risco, variando entre $0,0128 \%$ e $0,11 \%{ }^{(31,32)}$. A taxa de endoftalmite diminuiu com a facoemulsificação $(0,028 \%)$ em relação ao encontrado com a extração de catarata extracapsular $(0,25 \%){ }^{(35)}$. Em nosso serviço universitário, os residentes têm treinamento inicialmente com a técnica manual (facectomia extracapsular). Dentre os 22 casos do SUS, em três a técnica de facectomia extracapsular foi utilizada.

Além das mudanças de técnicas cirúrgicas ao longo dos anos, o uso intracameral de antibiótico como profilaxia nas cirurgias de catarata é um dos fatores que pode também influenciar na redução da incidência. A Sociedade Europeia de Cirurgiões de Catarata e Refrativa (European Society of Cataract \& Refractive Surgeons, ESCRS), em 2007, publicou os resultados de estudo randomizado multicêntrico, em que demonstraram que o uso intracameral de cefuroxime apresentou significativa redução de risco de endoftalmite, após cirurgia de catarata em relação ao uso tópico de levofloxacino ${ }^{(144)}$. Nota-se desde então, em diversos centros, uma significante redução da incidência de endoftalmite com o uso de cefuroxime intracameral, assim como com outros antibióticos, como vancomicina, moxifloxacino e cefazolina $(36,145,146)$. Mas, o uso de antibiótico intracameral profilático ainda permanece controverso em muitos países, por falta de antibiótico fracionado pronto para uso ${ }^{(147)}$. Isso faz com que a manipulação da medicação ocorra na sala operatória, aumentando o risco de contaminação. Com o aumento do uso profilático de antibiótico, torna-se ainda mais relevante a identificação do agente etiológico e da resistência ao antibiótico para monitorização da mudança dos espectros de 
microrganismos e prosseguir com medidas efetivas para o controle da infecção, caso seja necessário.

O espectro microbiológico nas endoftalmites pós-cirurgia de catarata foi avaliado pelo EVS em 291 amostras de 420 pacientes, sendo ressaltada a importância dos micrococcus coagulase-negativos presentes em $70 \%$ das amostras positivas. A positividade da cultura foi $69 \%{ }^{(8)}$. Este espectro microbiano sugere que estes organismos provêm da flora bacteriana do próprio paciente, que inclui micrococcus Gram-positivos coagulase-negativos. Em nossa casuística, dentre os 22 casos de endoftalmite pós-cirurgia de catarata, $41 \%$ foi por Staphylococcus epidermidis e $36 \%$ por bacilos Gram-negativos. Alguns fatores cirúrgicos podem estar associados a espectros microbianos distintos, como tipo de cirurgia e uso de antibiótico profilático.

A incidência de infecção relacionada às bolhas de cirurgia de glaucoma é maior e varia entre $1,1 \%$ e $2,2 \%$ em 5 anos ${ }^{(44,45)}$. Dos 19 casos de endoftalmite pós-cirurgia de glaucoma, nove tiveram manifestação precoce e 10 tardia. Em nossa casuística, a positividade foi baixa, em torno de 33\% (Tabela 11). Algumas hipóteses para esta baixa positividade seriam que amostras de humor aquoso sejam mais representativas pela proximidade à porta de entrada da infecção. No entanto, no serviço de urgências, há dificuldade de disponibilidade de sala cirúrgica e dificuldade de acesso a microscópio para realização da paracentese da câmara anterior, antes da punção vítrea. Nos casos coletados por biópsia vítrea, não foram realizadas punção da câmara anterior, e os casos submetidos à vitrectomia já haviam recebido antibiótico intravítreo, o que pode ter influenciado na baixa positividade dos casos pós-cirurgia de glaucoma. Em estudo multicêntrico, em um período de 5 anos, pelo grupo da Sociedade de Glaucoma no Japão, 170 casos de blebite foram avaliados ${ }^{(53)}$. A infecção foi classificada em estágio I quando confinada ao local da bolha; em estágio II, quando a infecção estava sobretudo na câmara anterior; e, em estágio III, quando a infecção envolvia o vítreo. Este último estágio foi subdivido em IIIa, quando o envolvimento vítreo era discreto e IIIb quando o envolvimento vítreo era avançado. É importante ressaltar essa divisão, pois a positividade da cultura diferiu, de acordo com o estágio, ressaltando a importância da coleta do humor aquoso. Neste estudo multicêntrico, a cultura foi positiva em 50\% dos casos, e a positividade foi maior no estágio IIIb (77\%) em relação ao estágio IIIa (39\%). Dentre os agentes isolados, foram observados cinco 
casos por Streptococcus e dois casos por bactérias Gram-negativas. Agentes mais virulentos são observados nas endoftalmites de manifestação tardia associadas à bolha, pois postula-se que haja migração transconjuntival de organismos presentes temporariamente por meio das bolhas de parede fina com a ação de exotoxinas ${ }^{(68)}$.

Os casos de endoftalmite pós-vitrectomia são raros com incidência entre $0,021 \%$ e $0,09 \%{ }^{(10,55)}$. A positividade da cultura encontrada por Garg et al. foi $47 \%$ (148). Em nossa casuística foram incluídos sete casos de endoftalmite pós-vitrectomia, com cultura positiva em somente um caso. Obteve-se uma positividade de $25 \%$ nas endoftalmites pós-operatórias agudas e, nos casos com suspeita de endoftalmite crônica, não foi possível detectar o agente etiológico em nenhum dos três casos por meio da cultura. No nosso fluxograma, nos casos de endoftalmite crônica nos quais a possibilidade de agentes anaeróbios e de fungos era maior, uma alíquota inicial do material foi colocado em tubo Falcon e fracionado posteriormente no laboratório para os vários meios, incluindo o frasco de hemocultura infantil. A baixa positividade nos casos de endoftalmite crônica nos remete a uma mudança neste fluxo; optamos pelo fracionamento pelo médico no ato da coleta, com inoculação direta do material no meio de cultura para anaeróbio e frasco de hemocultura aeróbio infantil. O PCR poderá acrescentar uma melhoraria no diagnóstico etiológico.

A incidência de endoftalmite após injeção intravítrea varia entre taxas muito baixas como 0,008\% a taxas elevadas como 0,092\% em razão, sobretudo, das condições nas quais a injeção é aplicada ${ }^{(59,60)}$. Gotículas de aerosóis, contendo contaminantes da flora oral do paciente ou da equipe médica são potenciais fonte de infecção. Em estudo por Daien et al., a taxa cumulativa de endoftalmite pós-injeção intravítrea para tratamento de degeneração macular relacionada à idade exsudativa, no período entre 2006 e 2016 foi $0,02 \%$, sendo progressivamente maior com o número maior de injeções por paciente; no entanto, o risco de endoftalmite não aumentou significativamente a cada injeção sucessiva (60). A política de "não falar" ("notalking”) está associada a um decréscimo no risco de endoftalmite ${ }^{(149)}$. Garg et al. comparando o prognóstico visual e o espectro microbiano em endoftalmite pós-injeção intravítrea e pós-vitrectomia, observaram que 56\% dos organismos nos casos associados à injeção intravítrea estavam associados à flora oral, como Streptococcus, com um pior prognóstico visual ${ }^{(148)}$. 
Endoftalmite endógena é menos comum que as endoftalmites exógenas e corresponde entre $10 \%$ e $18 \%$ dos casos de endoftalmite ${ }^{(150)}$. Em nossa casuística, dentre os 10 casos com endoftalmite endógena, em quatro casos o agente causal não foi identificado. Em dois destes casos a manifestação ocular foi anterior ao diagnóstico de quadro infeccioso sistêmico. Desta forma, o resultado negativo da cultura poderia indicar somente um processo inflamatório secundário à bacteremia sem presença ainda da bactéria no tecido ocular. O diagnóstico sistêmico foi meningite por Neisseria meningiditis e endocardite em hemocultura por Enterococcus. Os outros dois casos, já estavam usando antibiótico sistêmico na ocasião da coleta da cultura do humor vítreo, e as bactérias poderiam já ter sido erradicadas na ocasião da coleta. Estes dois casos eram pacientes imunossuprimidos. Nos casos com cultura positiva, foram detectados Staphylococcus aureus em três casos e Candida albicans em três casos. Em recente estudo de Bjerrum et al., a positividade da cultura em amostra vítrea foi $43 \%$ dos casos, sendo detectados Streptococcus e Staphylococcus aureus ${ }^{(150)}$.

\subsection{Aspectos relacionados ao espectro microbiano e sua relevância clínica}

O diagnóstico etiológico precoce pode auxiliar na conduta oftalmológica em diversos aspectos, seja para profilaxia e prevenção, como para adequar o tratamento e evitar um prognóstico já habitualmente tão reservado. Em nossa casuística, foram isoladas bactérias Gram-positivas em $84 \%$ das amostras, bactérias Gram-negativas em $11 \%$ e fungos em 5,4\%. Este espectro microbiano sugere que a maioria destes organismos provêm da flora bacteriana do próprio paciente, que inclui micrococcus Gram-positivos coagulase-negativos. $\mathrm{O}$ aumento da taxa de infecção por bactérias Gram-negativas, como Pseudomonas aeroginosa, muitas vezes como surtos, geralmente deve-se à contaminação de soluções oftálmicas, tais como azul tripan, fluido interno do facoemulsificador, solução da lente intraocular e da sonda do facoemulsificador. A P. aeruginosa sobrevive por longos períodos em ambientes aquosos $(120,151)$. A identificação de tais agentes é de extrema importância para se controlar surtos de endoftalmites, com a fiscalização dos processos de esterilização e orientação de cuidados pós-operatórios. 
Estudos com séries de casos com um mesmo patógeno permitem entender melhor a agressividade dos microrganismos. Para o S. lugdunensis, Chiquet et al. descreveram as características clínicas de cinco casos de endoftlamite pós-cirurgia de catarata, e, em dois casos, apresentaram acuidade visual final de 20/40, ou melhor, e três casos evoluíram com descolamento de retina. Os autores relacionaram esta maior agressividade em relação aos outros estafilococcus coagulase-negativos à produção de glicocalix extracelular que contribuem para a colonização da bactéria e interferem nas atividades associadas à fagocitose de neutrófilos e produção de enzimas ${ }^{(126)}$. Assim também, Streptococcus tiveram prognóstico visual ruim mesmo com a vitrectomia precoce, em menos de 48 horas ${ }^{(152)}$. A identificação rápida e precisa de agentes mais virulentos pode impactar em estratégias de tratamento e melhorar o prognóstico visual.

Em estudos descrevendo o prognóstico visual para Pseudomonas aeruginosa, em mais de 90\% dos casos apresentam acuidade visual final menor que 20/400 (120,151, 153). Em casos descritos por Enterococcus, o prognóstico visual é ruim mesmo com terapia precoce e adequada em razão da alta virulência do microrganismo ${ }^{(121,154,155)}$. Em nossa casuística, os dois casos por esses agentes tiveram prognóstico ruim, apesar da realização da vitrectomia precoce. Não foi verificada resistência à vancomicina para Enterococcus nem à ceftazidima para Pseudomonas, como descrito em algumas séries de casos $(156,157)$.

Em contrapartida a estes agentes mais agressivos, o prognóstico visual dos pacientes com endoftalmite pós-cirurgia de catarata por S. epidermidis é bom na maioria dos estudos, independente da forma de tratamento ${ }^{(117,158)}$. Em relação aos outros agentes acima descritos, o tempo para diagnóstico do S. epidermidis com EM MALDI-TOF direto é um pouco maior (TAT ID médio: E. faecalis 4,5h vs $P$. aeruginosa 13,2h vs S. epidermidis 23,8h; Tabela 8), provavelmente, pela menor quantidade de bactérias e menor virulência desse agente. Em nossa casuística, se forem considerados apenas os casos de cirurgia de catarata por $S$. epidermidis, dentre os nove casos, apenas dois tiveram prognóstico ruim. Destes dois casos, todos tiveram associação com complicações no intraoperatório. Recentemente, Clarke et al. propuseram um protocolo modificado do EVS. De imediato, após a suspeita clínica de endoftalmite, procede-se ao antibiótico oral e à biópsia vítrea com injeção de antibiótico. A avaliação da resposta clínica em 24 horas orientaria a necessidade de 
vitrectomia imediata ou não ${ }^{(112)}$. A rápida identificação do patógeno, em menos de 24 horas, com a técnica proposta em nosso estudo pela EM MALDI-TOF, poderá fornecer dados objetivos adicionais à resposta clínica. Além disso, torna-se possível o uso do antibiótico direcionado ao agente identificado em intervalo mais precoce, podendo impactar no prognóstico.

As recomendações para injeção intravítrea de vancomicina e ceftazidima foram seguidas para todos os pacientes. Conforme nosso TSA local, observou-se $100 \%$ de susceptibilidade à vancomicina em todos os microrganismos testados, e todas as bactérias Gram-positivas foram susceptíveis à vancomicina e todas as bactérias Gramnegativas à ceftazidima. Em relação aos $S$. epidermidis e $S$. haemolitycus, notou-se uma diminuição da susceptibilidade a ciprofloxacino, moxifloxacino, levofloxacino e oxacilina.

A resistência emergente aos antimicrobianos mais comumente usados é um grande desafio na Medicina ${ }^{(4)}$. O uso excessivo em hospitais, em clínicas, na agricultura, além de fatores genéticos contribui para este aumento de resistência antimicrobiana. Nos Estados Unidos da América e Europa ocorrem mais que 20.000 mortes a cada ano por organismos resistentes aos antimicrobianos. Em 2015, o Congresso Americano decretou um Ato de Prevenção à Resistência Antimicrobiana, definindo o uso de antibióticos em animais, mas o mesmo não foi aprovado diante da oposição da indústria farmacêutica. Em 2017, o centro de controle e prevenção de doença dos Estados Unidos da América (Centers for Disease Control and Prevention, CDC) iniciou um programa de gestão do uso consciente dos antibióticos (antimicrobial stewardship programme) com melhor seleção de antibióticos e redução do uso inapropriado de antibióticos de amplo espectro ${ }^{(4)}$. Como parte desse programa, a identificação exata das causas das infecções é imprescindível. Em Oftalmologia, o uso de antimicrobiano é, em sua maioria, utilizado como profilaxia de infecções relacionadas a procedimentos intraoculares. As evidências para seu uso são poucas com potenciais complicações, além das possíveis consequências da seleção da flora bacteriana.

Em 1994 quando o estudo do EVS sobre o espectro microbiano nas endoftalmites foi realizado, $100 \%$ dos isolados Gram-positivos eram susceptíveis à 
vancomicina. No entanto, dados recentes vêm apontando para resistência à vancomicina ${ }^{(157)}$. Para o teste de sensibilidade, a maioria dos laboratórios brasileiros segue as padronizações recomendadas pelo CLSI (Clinical and Laboratory Standards Institute, EUA). Entretanto, cada instituição seleciona quais antimicrobianos serão testados e reportados no TSA baseado em uma decisão conjunta entre o laboratório de microbiologia, o corpo clínico, a farmácia, o comitê terapêutico e a Comissão de Controle da Infecção Hospitalar (CCIH). Estudos como Antibiotic Resistance Monitoring in Ocular Microorganisms (ARMOR) nos Estados Unidos da América permitem avaliar as variações de susceptibilidade aos antimicrobianos ${ }^{(159)}$. No período entre 2009 e 2013, 3.237 amostras oculares foram analisadas quanto ao padrão de susceptibilidade aos antibióticos das bactérias Gram-positivas e Gram-negativas mais prevalentes nas infecções oculares, sendo observado que a resistência dos estafilococos à meticilina continua alta e com alta probabilidade de resistência concomitante às fluoquinolonas, aminoglicosídeos ou macrolídeos ${ }^{(159)}$. Vola et al. também observaram a tendência crescente da prevalência de infecção ocular por Staphylococcus aureus e, especialmente, cepas com resistência maior aos antibióticos (160). Embora no estudo da ARMOR não tenha sido observadas mudanças no padrão de susceptibilidade das bactérias Gram-negativas, estudos em outras partes do mundo vêm alertando para resistência a amicacina, ceftazidima e ciprofloxacino ${ }^{(156)}$.

A busca de métodos que permitam o diagnóstico etiológico rápido e preciso com definição de um tratamento específico e eficiente complementa os estudos que demonstram as variações de resistência aos antibióticos. 
7 Conclusões 


\section{CONCLUSÕES}

Neste estudo, a análise direta do humor vítreo, inoculado em frasco de hemocultura, por espectrometria de massa MALDI-TOF para identificação do agente etiológico, foi aplicada em 87 pacientes com suspeita de endoftalmites bacterianas e fúngicas.

7.1 A positividade na identificação do agente etiológico na cultura convencional foi $60,9 \%$. Nas amostras positivas para bactérias analisadas pela cultura convencional e pela EM MALDI-TOF, a concordância foi 81,1\%.

7.1.1 A concordância para bactérias Gram-positivas foi $80,4 \%$ e para bactérias Gram-negativas 100\%.

7.1.2 O tempo de identificação (turnaround time, TAT) pela análise direta com EM MALDI-TOF reduziu para uma mediana de 15 horas em relação ao TAT pela cultura convencional com mediana de 50,6 horas, com redução mediana de $67,6 \%$.

7.1.3 Ainda há limitações do método de identificação direta pela EM MALDI-TOF para o diagnóstico nos casos polimicrobianos e para realização de sensibilidade aos antibióticos.

7.1.4 Nos casos de endoftalmite fúngica, EM MALDI-TOF foi concordante com o resultado da cultura convencional em todos os casos. 
7.2 A padronização do uso de frasco de hemocultura infantil e o fluxograma de coleta proposto pelo estudo contribuíram para positividade de $60,9 \%$ na detecção do agente etiológico nas endoftalmites infecciosas, comparável aos melhores resultados da literatura internacional.

7.3 Os agentes mais prevalentes das endoftalmites infecciosas nesta casuística foram Staphylococcus epidermidis, Staphylococcus aureus e Streptococcus pneumoniae.

7.3.1 A positividade na identificação do agente etiológico foi em mais de $70 \%$ para casos de endoftalmite pós-operatória aguda, após cirurgia de catarata, injeção intravítrea, pós-remoção de sutura e após trauma.

7.3.2 A positividade foi abaixo de $30 \%$ na identificação de patógenos nos casos de endoftalmite crônica e endoftalmite aguda após cirurgia de glaucoma, vitrectomia e endoftalmite endógena. Esta baixa sensibilidade nestas situações clínicas implica necessidade de otimização dos métodos utilizados.

7.3.3 O prognóstico visual foi melhor nos casos de endoftalmite por Staphylococcus epidermidis com acuidade visual melhor ou igual a $20 / 60$ e $20 / 200$, em $60 \%$ e em $86,7 \%$ dos casos, respectivamente.

7.3.4 Para os demais agentes, apenas $11,8 \%$ tiveram acuidade visual melhor ou igual a $20 / 200$.

7.3.5 Em relação à sensibilidade, observou-se resistência a ciprofloxacino, moxifloxacino e oxacilina nos casos de endoftalmite por 
Staphylococcus epidermidis e Staphylococcus haemolyticus. Todas as amostras foram sensíveis à vancomicina e à ceftazidima.

7.4 Quanto a fatores que podem interferir na positividade dos resultados de identicação do patógeno no presente estudo, não foi observada significância estatística em nenhum deles. A saber:

7.4.1 O uso de antibiótico intravítreo não interferiu na positividade na detecção do agente etiológico;

7.4.2 O humor vítreo não diluído e diluído mostrou-se semelhante quanto à positividade na detecção do agente etiológico assim como no tempo de identificação pela análise direta pela EM MALDI-TOF;

7.4.3 Quanto ao primeiro procedimento, se biópsia vítrea ou vitrectomia, não interferiram nos resultados.

Com o presente estudo, a identificação do agente etiológico pela análise direta do humor vítreo, inoculado em frasco de hemocultura, por espectrometria de massas MALDI-TOF mostrou-se uma técnica rápida e viável para uso na prática clínica. A rápida identificação do microrganismo possibilitará um melhor manejo no uso de antibióticos e um melhor prognóstico visual ao paciente. 
8 Referências 


\section{REFERÊNCIA}

1. Gower EW, Keay LJ, Stare DE, Arora P, Cassard SD, Behrens A, Tielsch JM, Schein OD. Characteristics of endophthalmitis after cataract surgery in the United States medicare population. Ophthalmology. 2015;122(8):1625-32.

2. Lundström M, Friling E, Montan P. Risk factors for endophthalmitis after cataract surgery: Predictors for causative organisms and visual outcomes. J Cataract Refract Surg. 2015;41(11):2410-6.

3. Brillat-Zaratzian E, Bron A, Aptel F, Romanet JP, Cornut PL, Vandenesch F, Boisset S, Maurin M, Chiquet C. FRIENDS Group: clinical and microbiological characteristics of post-filtering surgery endophthalmitis. Graefe's Arch Clin Exp Ophthalmol. 2014;252(1):101-7.

4. Relhan N, Pathengay A, Schwartz SG, Flynn HW. Emerging worldwide antimicrobial resistance, antibiotic stewardship and alternative intravitreal agents for the treatment of endophthalmitis. Retina. 2017;37(5):811-8.

5. Graue-Hernandez EO, Naranjo A, Flynn HW, Ahmed I, Navas A, Amescua G, et al. Toxic anterior segment syndrome: a review. Surv Ophthalmol. 2019 Jan 28. pii: S0039-6257(18)30191-7.

6. Rachitskaya A V., Flynn HW, Wong J, Kuriyan AE, Miller D. A 10-year study of membrane filter system versus blood culture bottles in culturing vitrectomy cassette vitreous in infectious endophthalmitis. Am J Ophthalmol. 2013;156(2):349-354.e2.

7. Bispo PJM, Melo GB De, D’Azevedo PA, Höfling-Lima AL, Yu MCZ, Pignatari ACC. [Culture proven bacterial endophthalmitis: a 6-year review]. Arq Bras Oftalmol. 2008;71(5):617-22. 
8. Group S. Results of the Endophthalmitis Vitrectomy Study. Arch Ophthalmol. 1995;113(12):1479.

9. Okhravi N, Towler HM, Hykin P, Matheson M, Lightman S. Assessment of a standard treatment protocol on visual outcome following presumed bacterial endophthalmitis. Br J Ophthalmol. 1997;81(9):719-25.

10. Kunimoto DY, Kaiser RS. Incidence of endophthalmitis after 20- and 25Gauge vitrectomy. Ophthalmology. 2007;114(12):2133-7.

11. Mishra D, Satpathy G, Chawla R, Venkatesh P, Ahmed NH, Panda SK. Utility of broad-range 16S rRNA PCR assay versus conventional methods for laboratory diagnosis of bacterial endophthalmitis in a tertiary care hospital. $\mathrm{Br}$ J Ophthalmol. 2019;103(1):152-6.

12. Eser I, Kapran Z, Altan T, Eren H, Yilmaz OF. The use of blood culture bottles in endophthalmitis. Retina. 2007 Sep;27(7):971-3.

13. Yospaiboon Y, Saree S PS. Blood culture and conventional media for vitreous culture in infectious endophthalmitis. J Med Assoc Thai. 2005;88(5):639-42.

14. Tanaka T, Ferreira BF de A, Oliveira LMS de, Kato JM, Gioia TSR Di, Rossi F, Nakashima Y, Pimentel SLG, Yamamoto JH, Almeida Junior JN. Diagnostic value of pediatric blood culture bottles for acute postoperative endophthalmitis. Clinics. 2019;74:e837.

15. Croxatto A, Prod'hom G, Greub G. Applications of MALDI-TOF mass spectrometry in clinical diagnostic microbiology. FEMS Microbiol Rev. 2012;36(2):380-407. 
16. Lagacé-Wiens PRS, Adam HJ, Karlowsky JA, Nichol KA, Pang PF, Guenther J, Webb AA, Miller C, Alf mj. Identification of blood culture isolates directly from positive blood cultures by use of matrix-assisted laser desorption ionization-time of flight mass spectrometry and a commercial extraction system: Analysis of performance, cost, and turnaround time. J Clin Microbiol. 2012;50(10):3324-8.

17. Bizzini A, Greub G. Matrix-assisted laser desorption ionization time-of-flight mass spectrometry, a revolution in clinical microbial identification. Clin Microbiol Infect. 2010;16(11):1614-9.

18. Durand ML. Bacterial and Fungal Endophthalmitis. Clin Microbiol Rev. 2017;30(3):597-613.

19. Schwartz SG, Flynn HW, Das T, Mieler WF. Ocular infection: Endophthalmitis. Dev Ophthalmol. 2016;55:176-88.

20. Vaziri K, Pershing S, Albini TA, Moshfeghi DM, Moshfeghi AA. Risk factors predictive of endogenous endophthalmitis among hospitalized patients with hematogenous infections in the United States. Am J Ophthalmol. 2015;159(3):498-504.

21. Aaberg T. Nosocomial acute-onset postoperative endophthalmitis survey A 10-year review of incidence and outcomes. Ophthalmology. 1998;105(6):1004-10.

22. Melo GB, Bispo PJM, Yu MCZ, Pignatari ACC, Höfling-Lima AL. Microbial profile and antibiotic susceptibility of culture-positive bacterial endophthalmitis. Eye. 2011;25(3):382-8.

23. Gupta A, Orlans HO, Hornby SJ, Bowler ICJW. Microbiology and visual outcomes of culture-positive bacterial endophthalmitis in Oxford, UK. Graefe's Arch Clin Exp Ophthalmol. 2014;252(11):1825-30. 
24. Moloney TP, Park J. Microbiological isolates and antibiotic sensitivities in culture-proven endophthalmitis: a 15-year review. Br J Ophthalmol. 2014;98(11):1492-7.

25. Sharma S, Padhi TR, Basu S, Kar S, Roy A, Das T. Endophthalmitis patients seen in a tertiary eye care centre in Odisha : A clinico-microbiological analysis. Indian J Med Res. 2014;139(1):91-8.

26. Nam KY, Lee JE, Lee JE, Jeung WJ, Park JM, Park JM, Chung IY, Han YS, Yun IH, Kim HW, Byon IS, Oum BS, Yoon HS, Park D, Yu BC, Park EK, Lee HJ, Lee SJ. Clinical features of infectious endophthalmitis in South Korea: a five-year multicenter study. BMC Infect Dis. 2015;15(1):177.

27. Falavarjani K, Hashemi M, Modarres M, Nekoozadeh S, Parvaresh M, Soodi $\mathrm{R}$, Alemzadeh SA. Isolates and antibiotic resistance of culture-proven endophthalmitis cases presented to a referral center in Tehran. Middle East Afr J Ophthalmol. 2012;19(4):361-3.

28. Kessner R, Golan S, Barak A. Changes in the etiology of endophthalmitis from 2003 to 2010 in a large tertiary medical center. Eur J Ophthalmol. 2014;24(6):918-24.

29. Gharamah A, Moharram A, Ismail M, AL-Hussaini A. Bacterial and fungal endophthalmitis in Upper Egypt: related species and risk factors. Asian Pac J Trop Biomed. 2012;2(8):655-9.

30. Duan F, Wu K, Liao J, Zheng Y, Yuan Z, Tan J, Lin X. Causative microorganisms of infectious endophthalmitis: a 5-year retrospective study. J Ophthalmol. 2016;2016:67641921-7.

31. Taban M, Behrens A, Newcomb RL, Nobe MY, Saedi G, Sweet PM, McDonnell PJ. Acute endophthalmitis following cataract surgery. Arch Ophthalmol. 2005;123(5):613-20. 
32. Zhu Y, Chen X, Chen P, Wu J, Hua H, Yao K. The occurrence rate of acuteonset postoperative endophthalmitis after cataract surgery in Chinese smalland medium-scale departments of ophthalmology. Sci Rep. 2017;7:40776.

33. Melo GB, Bispo PJM, Regatieri CVS, Yu MCZ, Pignatari ACC, HöflingLima AL. Incidence of endophthalmitis after cataract surgery (2002-2008) at a Brazilian university-hospital. Arq Bras Oftalmol. 2010;73(6):505-7.

34. Miller JJ, Scott IU, Flynn HW, Smiddy WE, Newton J, Miller D. Acute-onset endophthalmitis after cataract surgery (2000-2004): incidence, clinical settings, and visual acuity outcomes after treatment. Am J Ophthalmol. 2005;139(6):983-7.

35. Abulafia A, Rosen E, Assia EI, Kleinmann G. Establishment of a registry to monitor trends in cataract surgical procedures and outcomes in Israel, 19902014. Isr Med Assoc J. 2015;17(12):755-9.

36. Lundström M, Wejde G, Stenevi U, Thorburn W, Montan P. Endophthalmitis after cataract surgery. a nationwide prospective study evaluating incidence in relation to incision type and location. Ophthalmology. 2007;114(5):866-70.

37. Lalitha P, Sengupta S, Ravindran RD, Sharma S, Joseph J, Ambiya V, Das T. A literature review and update on the incidence and microbiology spectrum of postcataract surgery endophthalmitis over past two decades in India. Indian J Ophthalmol. 2017;65(8):673-7.

38. Wong TY, Chee S. The epidemiology of acute endophthalmitis after cataract surgery in an Asian population. Ophthalmology. 2004;111(4):699-705.

39. Inoue T, Uno T, Usui N, Kobayakawa S, Ichihara K, Ohashi Y. Incidence of endophthalmitis and the perioperative practices of cataract surgery in Japan: Japanese Prospective Multicenter Study for Postoperative Endophthalmitis after Cataract Surgery. Jpn J Ophthalmol. 2018;62(1):24-30. 
40. Wykoff CC, Parrott MB, Flynn HW, Shi WEI, Miller D, Alfonso EC. Nosocomial acute-onset postoperative endophthalmitis at a university teaching hospital ( 2002-2009). Am J Ophthalmol. 2010;150(3):392-8.e2.

41. Leng T, Miller D, Flynn HW, Jacobs DJ, Gedde SJ. Delayed-onset blebassociated endophthalmitis (1996-2008): causative organisms and visual acuity outcomes. Retina. 2011;31(2):344-52.

42. Vaziri K, Kishor K, Schwartz SG, Maharaj AS, Moshfeghi DM, Moshfeghi AA, Flynn HW Jr. Incidence of bleb-associated endophthalmitis in the United States. Clin Ophthalmol. 2015;9:317-22.

43. Kim EA, Law SK, Coleman AL, Nouri-Mahdavi K, Giaconi JA, Yu F, Lee JW, Caprioli J. Long-term bleb-related infections after trabeculectomy: Incidence, risk factors, and influence of bleb revision. Am J Ophthalmol. 2015;159(6):1082-91.

44. Zahid S, Musch DC, Niziol LM, Lichter PR. Risk of endophthalmitis and other long-term complications of trabeculectomy in the collaborative initial glaucoma treatment study (CIGTS). Am J Ophthalmol. 2013;155(4):674680.e1.

45. Yamamoto T, Sawada A, Mayama C, Araie M, Ohkubo S, Sugiyama K, Kuwayama Y, Collaborative Bleb-Related Infection Incidence and Treatment Study Group. The 5-year incidence of bleb-related infection and its risk factors after filtering surgeries with adjunctive mitomycin $\mathrm{C}$ : collaborative bleb-related infection incidence and treatment study 2. Ophthalmology. 2014;121(5):1001-6.

46. Brown RH, Yang LH, Walker SD, Lynch MG, Martinez LA, Wilson LA. Treatment of bleb infection after glaucoma surgery. Arch Ophthalmol (Chicago, Ill 1960). 1994;112(1):57-61. 
47. Mochizuki K, Jikihara S, Ando Y, Hori N, Yamamoto T, Kitazawa Y. Incidence of delayed onset infection after trabeculectomy with adjunctive mitomycin C or 5-fluorouracil treatment. Br J Ophthalmol. 1997;81(10):87783.

48. Lehmann OJ, Bunce C, Matheson MM, Maurino V, Khaw PT, Wormald R, Barton K. Risk factors for development of post-trabeculectomy endophthalmitis. Br J Ophthalmol. 2000;84(12):1349-53.

49. Soltau JB, Rothman RF, Budenz DL, Greenfield DS, Feuer W, Liebmann JM, Ritch R. Risk factors for glaucoma filtering bleb infections. Arch Ophthalmol (Chicago, Ill 1960). 2000;118(3):338-42.

50. DeBry PW, Perkins TW, Heatley G, Kaufman P, Brumback LC. Incidence of late-onset bleb-related complications following trabeculectomy with mitomycin. Arch Ophthalmol (Chicago, Ill 1960). 2002;120(3):297-300.

51. Kangas TA, Greenfield DS, Flynn HW, Parrish RK, Palmberg P. Delayedonset endophthalmitis associated with conjunctival filtering blebs. Ophthalmology. 1997;104(5):746-52.

52. Katz LJ, Cantor LB, Spaeth GL. Complications of surgery in glaucoma. Early and late bacterial endophthalmitis following glaucoma filtering surgery. Ophthalmology. 1985;92(7):959-63.

53. Yamamoto T, Kuwayama Y, Kano K, Sawada A, Shoji N. Clinical features of bleb-related infection: A 5-year survey in Japan. Acta Ophthalmol. 2013;91(7):619-24.

54. Eifrig CWG, Flynn HW, Scott IU, Newton J. Acute-onset postoperative endophthalmitis: review of incidence and visual outcomes (1995-2001). Ophthalmic Surg Lasers. 33(5):373-8. 
55. Shimada H, Nakashizuka H, Hattori T, Mori R, Mizutani Y, Yuzawa M. Incidence of endophthalmitis after 20- and 25-gauge vitrectomy. Causes and prevention. Ophthalmology. 2008;115(12):2215-20.

56. Bhende M, Raman R, Jain M, Shah PK, Sharma T, Gopal L, Bhende PS, Srinivasan S, Jambulingam M; Sankara Nethralaya Vitreoretinal Study Group (SNVR-Study Group). Incidence, microbiology, and outcomes of endophthalmitis after 111,876 pars plana vitrectomies at a single, tertiary eye care hospital. PLoS One. 2018;13(1):e0191173.

57. Scott IU, Flynn HW, Acar N, Dev S, Shaikh S, Mittra RA, Arevalo JF, Kychenthal A, Kunselman A. Incidence of endophthalmitis after 20-gauge vs 23-gauge vs 25-gauge pars plana vitrectomy. Graefe's Arch Clin Exp Ophthalmol. 2011;249(3):377-80.

58. Schwartz SG, Flynn HW, Das T, Mieler WF. Ocular infection: endophthalmitis. Dev Ophthalmol. 2015;55:176-88.

59. Mithal K, Mathai A, Pathengay A, Jalali S, Relhan N, Motukupally SR, Sharma S, Das T. Endophthalmitis following intravitreal anti-VEGF injections in ambulatory surgical centre facility: incidence, management and outcome. Br J Ophthalmol. 2013;97(12):1609-12.

60. Daien V, Nguyen V, Essex RW, Morlet N, Barthelmes D, Gillies MC, Fight Retinal Blindness Study Group. Incidence and outcomes of infectious and noninfectious endophthalmitis after intravitreal injections for age-related macular degeneration. Ophthalmology. 2018;125(1):66-74.

61. Cornut P-L, Youssef EB, Bron A, Thuret G, Gain P, Burillon C, Romanet JP, Vandenesch F, Maurin M, Creuzot-Garcher C, Chiquet C; French Institutional Endophthalmitis Study (FRIENDS) Group. A multicentre prospective study of post-traumatic endophthalmitis. Acta Ophthalmol. 2013;91(5):475-82. 
62. Essex R, YI Q, Charles P, Allen P. Post-traumatic endophthalmitis. Ophthalmology. 2004;111(11):2015-22.

63. Durand ML, Miller JW, Young LH (eds). Endophthalmitis. Cham: Springer International Publishing; 2016.

64. Cao H, Zhang L, Li L, Lo S. Risk factors for acute endophthalmitis following cataract surgery : a systematic review and meta- analysis. PloS One. 2013;8(8):e71731.

65. Ciulla TA, Starr MB, Masket S. Bacterial endophthalmitis prophylaxis for cataract surgery: an evidence-based update. Ophthalmology. 2002;109(1):1324.

66. Razeghinejad MR, Havens SJ, Katz LJ. Trabeculectomy bleb-associated infections. Surv Ophthalmol. 2016;1-20.

67. Aubin GG, Portillo ME, Trampuz A, Corvec S. Propionibacterium acnes, an emerging pathogen: From acne to implant-infections, from phylotype to resistance. Med Mal Infect. 2014;44(6):241-50.

68. Yassin SA. Bleb-related infection revisited: A literature review. Acta Ophthalmol. 2016;94(2):122-34.

69. Gokce G, Sobaci G, Ozgonul C. Post-traumatic endophthalmitis: a minireview. Semin Ophthalmol. 2015;30(5-6):470-4.

70. Samson CM, Foster CS. Chronic postoperative endophthalmitis. Int Ophthalmol Clin. 2000;40(1):57-67.

71. Tan HS, Spanjaard L, Smet MD De. The additional value of blood culture bottles in the diagnosis of endophthalmitis. Eye. 2011;25(8):1069-73. 
72. Pongsachareonnont P, Honglertnapakul W, Chatsuwan T. Comparison of methods for identifying causative bacterial microorganisms in presumed acute endophthalmitis: conventional culture, blood culture, and PCR. BMC Infect Dis. $2017 ; 17(1): 165$.

73. Ramakrishnan R, Bharathi MJ, Shivkumar C, Mittal S, Meenakshi R, Khadeer $\mathrm{M}$ a, et al. Microbiological profile of culture-proven cases of exogenous and endogenous endophthalmitis: a 10-year retrospective study. Eye. 2009;23(4):945-56.

74. Carrim ZI, Richardson J, Wykes WN. Incidence and visual outcome of acute endophthalmitis after cataract surgery - the experience of an eye department in Scotland. 2009;(93):721-5.

75. Joondeph BC, Flynn HWJ, Miller D, Joondeph HC. A new culture method for infectious endophthalmitis. Arch Ophthalmol. 1989;107(9):1334-7.

76. Carroll KC, Pfaller MA, Landry LM, K M, Patel R, Richter SS, et al. (eds.). Manual of Clinical Microbiology, Twelfth Edition. American Society of Microbiology; 2019.

77. Kratz A, Levy J, Belfair N, Weinstein O, Klemperer I, Lifshitz T. Broth culture yield vs traditional approach in the work-up of endophthalmitis. Am J Ophthalmol. 2006;141(6):1022-6.e2.

78. Church DL, Davies HD, Rt GC, Trevenen CL. Comparative study of three different BACTEC culture media for the detection of bacteremia in ambulatory and hospitalized children. Can J Infect Dis. 1998;9(2):77-82.

79. Lelièvre H, Gimenez M, Vandenesch F, Reinhardt A, Lenhardt D, Just HM, Pau M, Ausina V, Etienne J, Multicenter clinical comparison of resincontaining bottles with standard aerobic and anaerobic bottles for culture of microorganisms from blood. Eur J Clin Microbiol Infect Dis. 1997;16(9):669-74. 
80. Spaargaren J, van Boven CP, Voorn GP. Effectiveness of resins in neutralizing antibiotic activities in bactec plus Aerobic/F culture medium. J Clin Microbiol. 1998;36(12):3731-3.

81. Rohner P, Pepey B, Auckenthaler R. Advantage of combining resin with lytic BACTEC blood culture media. J Clin Microbiol. 1997;35(10):2634-8.

82. Gokbolat E, Oz Y, Metintas S. Evaluation of three different bottles in BACTEC 9240 automated blood culture system and direct identification of Candida species to shorten the turnaround time of blood culture. J Med Microbiol. 2017;66(4):470-6.

83. Lee AY, Akileswaran L, Tibbetts MD, Garg SJ, Van Gelder RN. Identification of torque teno virus in culture-negative endophthalmitis by representational deep DNA sequencing. Ophthalmology. 2015;122(3):524-30.

84. Anhalt J, Fenselau C. Identification of bacteria using mass spectrometry. Anal Chem. 1975;47:219-25.

85. Tanaka K, Waki H, Ido Y, Akita S, Yoshida Y, Yoshida T. T. Protein and polymer analyses up to $\mathrm{m} / \mathrm{z} 100000$ by laser ionization time-of flight mass spectrometry. Rapid Commun Mass Spectrom. 1988;20:151-3.

86. Buchan BW, Riebe KM, Ledeboer NA. Comparison of the MALDI biotyper system using sepsityper specimen processing to routine microbiological methods for identification of bacteria from positive blood culture bottles. J Clin Microbiol. 2012;50(2):346-52.

87. Kok J, Chen SCA, Dwyer DE, Iredell JR. Current status of matrix-assisted laser desorption ionisation-time of flight mass spectrometry in the clinical microbiology laboratory. Pathology. 2013;45(1):4-17. 
88. Schubert S, Kostrzewa M. MALDI-TOF MS in the microbiology laboratory: current trends. Curr Issues Mol Biol. 2017;23:17-20.

89. French K, Evans J, Tanner H, Gossain S, Hussain A. The clinical impact of rapid, direct MALDI-ToF identification of bacteria from positive blood cultures. PLoS One. 2016;11(12):1-9.

90. Huang AM, Newton D, Kunapuli A, Gandhi TN, Washer LL, Isip J, Collins CD, Nael JL. Impact of rapid organism identification via matrix-assisted laser desorption/ionization time-of-flight combined with antimicrobial stewardship team intervention in adult patients with bacteremia and candidemia. Clin Infect Dis. 2013;57(9):1237-45.

91. Spanu T, Posteraro B, Fiori B, D’Inzeo T, Campoli S, Ruggeri A, Tumbarello M, Canu G, Trecarichi EM, Parisi G, Tronci M, Sanguinetti M, Fadda G. Direct MALDI-TOF mass spectrometry assay of blood culture broths for rapid identification of candida species causing bloodstream infections: an observational study in two large microbiology laboratories. J Clin Microbiol. 2012;50(1):176-9.

92. Sakai T, Kohzaki K, Watanabe A, Tsuneoka H, Shimadzu M. Use of DNA microarray analysis in diagnosis of bacterial and fungal endophthalmitis. Clin Ophthalmol. 2012;6:321-6.

93. Patel N, Miller D, Relhan N, Flynn HW. Peptide nucleic acid-fluorescence in situ hybridization for detection of staphylococci from endophthalmitis isolates: A proof-of-concept study. Investig Ophthalmol Vis Sci. 2017;58(10):4027-9.

94. Ogawa M, Sugita S, Shimizu N, Watanabe K, Nakagawa I, Mochizuki M. Broad-range real-time PCR assay for detection of bacterial DNA in ocular samples from infectious endophthalmitis. Jpn J Ophthalmol. 2012;56(6):52935. 
95. Chiquet $\mathrm{C}$, Cornut $\mathrm{P}$, Benito $\mathrm{Y}$, Thuret $\mathrm{G}$, Maurin M, Lafontaine P, Pechinot A, Palombi K, Lina G, Bron A, Denis P, Carricajo A, Creuzot C, Romanet JP, Vandenesch F; French Institutional Endophthalmitis Study Group. Eubacterial PCR for bacterial detection and identification in 100 acute postcataract surgery endophthalmitis. Investig Opthalmology Vis Sci. 2008;49(5):1971-8.

96. Bispo PJM, de Melo GB, Hofling-Lima AL, Pignatari ACC. Detection and gram discrimination of bacterial pathogens from aqueous and vitreous humor using real-time PCR assays. Investig Ophthalmol Vis Sci. 2011;52(2):873-81.

97. Sandhu HS, Hajrasouliha A, Kaplan HJ, Wang W. Diagnostic utility of quantitative polymerase chain reaction versus culture in endophthalmitis and uveitis. Ocul Immunol Inflamm. 2018Feb 22:1-5.

98. Cornut P-L, Boisset S, Romanet J-P, Maurin M, Carricajo A, Benito Y, Vandenesch F, Chiquet C. Principles and applications of molecular biology techniques for the microbiological diagnosis of acute post-operative endophthalmitis. Surv Ophthalmol. 2014;59(3):286-303.

99. Deshmukh D, Joseph J, Chakrabarti M, Sharma S, Jayasudha R, Sama KC, Sontam B, Tyagi M, Narayanan R, Shivaji S. New insights into culture negative endophthalmitis by unbiased next generation sequencing. Sci Rep. 2019;9(1):844.

100. Abrishami M, Hashemi B, Abrishami M, Abnous K, Razavi-Azarkhiavi K, Behravan J. PCR detection and identification of bacterial contaminants in ocular samples from post-operative endophthalmitis. J Clin Diagnostic Res. 2015;9(4):NC01-3.

101. Hong BK, Lee CS, Gelder RN Van, Garg SJ. Retina A. Emerging techniques for pathogen discovery in endophthalmitis. Curr Opin Ophthalmol. $2015 ; 26(3): 221-5$. 
102. Sugita S, Shimizu N, Watanabe K, Mizukami M, Morio T, Sugamoto Y, Mochiziki M. Use of multiplex PCR and real-time PCR to detect human herpes virus genome in ocular fluids of patients with uveitis. Br J Ophthalmol. 2008;92(7):928-32.

103. Adalberto De Luz R, Padoveze MC, Cvintal T. Epidemiologic surveillance of postoperative endophthalmitis in a specialized ophthalmologic center in São Paulo, Brazil. Am J Infect Control. 2012;40(1):e1-3.

104. Giampani Junior J, Borges-Giampani AS, Carani JCE, Oltrogge EW, Susanna Junior R. Efficacy and safety of trabeculectomy with mitomycin C for childhood glaucoma: a study of results with long-term follow-up. Clinics. 2008;63(4):421-6.

105. Guerra RLL, De Paula Freitas B, Parcero CMFM, Maia Júnior O de O, Marback RL. An outbreak of forty five cases of Pseudomonas aeruginosa acute endophthalmitis after phacoemulsification. Arq Bras Oftalmol. 2012;75(5):344-7.

106. Bispo PJM, Höfling-Lima AL, Pignatari ACC. Molecular biology applied to the laboratory diagnosis of bacterial endophthalmitis. Arq Bras Oftalmol. 2009;72(5):734-40.

107. Therese KL, Anand AR, Madhavan HN. Polymerase chain reaction in the diagnosis of bacterial endophthalmitis. Br J Ophthalmol. 1998;82(9):1078-82.

108. Goldschmidt P, Degorge S, Benallaoua D, Basli E, Batellier L, Boutboul S, Allouch C, Borderie V, Laroche L, Chaumeil C. New test for the diagnosis of bacterial endophthalmitis. Br J Ophthalmol. 2009;93(8):1089-95. 
109. Melo GB, Bispo PJM, Campos Pignatari AC, Höfling-Lima AL. Real-time polymerase chain reaction test to discriminate between contamination and intraocular infection after cataract surgery. J Cataract Refract Surg. 2011;37(7):1244-50.

110. Grzybowski A, Turczynowska M, Kuhn F. The treatment of postoperative endophthalmitis: Should we still follow the endophthalmitis vitrectomy study more than two decades after its publication? Acta Ophthalmol. 2018;96(5)e651-654.

111. Ho I-V, Fernandez-Sanz G, Levasseur S, Ting E, Liew G, Playfair J, Downie J, Gorbatov M, Hunyor AP, Chang AA. Early pars plana vitrectomy for treatment of acute infective endophthalmitis. Asia-Pacific J Ophthalmol. 2019;8(1):3-7.

112. Clarke B, Williamson T, Gini G, Gupta B. Management of bacterial postoperative endophthalmitis and the role of vitrectomy. Surv Ophthalmol. 2018;63(5):677-93.

113. Choi EY, Han JY, Lee H, Lee SC, Koh HJ, Kim SS, Kim M. Impact of antibiotic resistance of pathogens and early vitrectomy on the prognosis of infectious endophthalmitis : a 10-year retrospective study. Graefes Arch Clin Exp Ophthalmol. 2019;257(4):805-813.

114. Holland EJ, Mcdonald MB, Parekh JG, Sheppard JD. Antibiotic Resistance in Acute Postoperative Endophthalmitis. Ophthalmology. 2014;121(11):S1-9.

115. Bantar C, Sartori B, Vesco E, Heft C, Saúl M, Salamone F, Oliva ME. A hospitalwide intervention program to optimize the quality of antibiotic use: impact on prescribing practice, antibiotic consumption, cost savings, and bacterial resistance. Clin Infect Dis. 2003;37(2):180-6. 
116. Messacar K, Parker SK, Todd JK, Dominguez SR. Implementation of rapid molecular infectious disease diagnostics: The role of diagnostic and antimicrobial stewardship. J Clin Microbiol. 2017;55(3):715-23.

117. Yannuzzi NA, Patel NA, Relhan N, Tran KD, Si N, Albini TA, et al. Clinical features, antibiotic susceptibilities, and treatment outcomes of endophthalmitis caused by Staphylococcus epidermidis. Ophthalmol Retin. 2018;2(5):396-400.

118. Chiquet C, Musson C, Aptel F, Boisset, Maurin M. Genetic and phenotypic traits of S. epidermidis strains causing post-cataract endophthalmitis compared to commensal conjunctival flora. Am J Ophthalmol. 2018;191:76-82

119. Chon J, Kim M. Successful management of late-onset Streptococcus mitis endophthalmitis. Ther Clin Risk Manag. 2017;13:1439-42.

120. Sridhar J, Kuriyan AE, Flynn HW, Miller D. Endophthalmitis caused by Pseudomonas aeruginosa. Retina. 2015;35(6):1101-6.

121. Dave V, Pathengay A, Braimah I, Panchal B, Sharma S, Pappuru RR, Mathai A, Tyagi M, Narayanan R, Jalali S, Das T. Enterococcus endophthalmitis clinical settings, antimicrobial susceptibility, and management outcomes. Retina. 2019 Jan 23:1-5.

122. Levin AS, Oliveira MS, Dias MBG de S (editores). Guia de utilização de anti-infecciosos e recomendações para a prevenção de infecções hospitalares. 7th ed. ,São Paulo: HCFMUSP; 2018. 67 p.

123. Lamy B, Dargère S, Arendrup MC, Parienti JJ, Tattevin P. How to optimize the use of blood cultures for the diagnosis of bloodstream infections? A stateof-the art. Front Microbiol. 2016;7(May):1-13. 
124. Pulcrano G, Roscetto E, Iula VD, Panellis D, Rossano F, Catania MR. MALDI-TOF mass spectrometry and microsatellite markers to evaluate Candida parapsilosis transmission in neonatal intensive care units. Eur J Clin Microbiol Infect Dis. 2012;31(11):2919-28.

125. Jindal A, Moreker MR, Pathengay A, Khera M, Jalali S, Majji A, Mathai A, Sharma S, Das T, Flynn HW Jr. Polymicrobial endophthalmitis : prevalence, causative organisms, and visual outcomes. J Ophthalmic Inflamm Infect. 2013;3(1):6.

126. Chiquet C, Pechinot A, Creuzot-Garcher C, Benito Y, Croize J, Boisset S, Romanet JP, Lina G, Vandenesch F; French Institutional Endophthalmitis Study Group. Acute postoperative endophthalmitis caused by Staphylococcus lugdunensis. J Clin Microbiol. 2007;45(6):1673-8.

127. Saraiva F, Costa PG, Inomata DL, Preti RC, Helal Jr J, Nakashima Y. Clinical profile of patients with endophthalmitis hospitalized at Hospital das Clínicas of São Paulo. Rev Bras Oftalmol. 2007;66(3):169-74.

128. Saffra N, Moriarty E, Milman T. Bilateral sequential Propionibacterium acnes exogenous endophthalmitis. J Ophthalmic Inflamm Infect. 2016;6(1):16-8.

129. Clark AE, Kaleta EJ, Arora A, Wolk M. Matrix-assisted laser desorption ionization - time of flight mass spectrometry : a fundamental shift in the routine practice of clinical microbiology. Clin Microbiol Rev. 2013;26(3):547603.

130. Carreno JJ, Lomaestro BM, Jacobs AL, Meyer RE, Evans A, Montero CI. Assessment of time to clinical response in patients with sepsis treated before and after implementation of a matrix-assisted laser desorption ionization timeof-flight blood culture identification algorithm. Infect Control Hosp Epidemiol. 2016;37(8):1-8. 
131. Mailhac A, Durand H, Boisset S, Maubon D, Berger F, Maurin M, Chiquet C, Bidart M. MALDI-TOF mass spectrometry for rapid diagnosis of postoperative endophthalmitis. J Proteomics. 2017;152:150-2.

132. Callegan MC, Booth MC, Jett BD, Gilmore MS. Pathogenesis of Grampositive bacterial endophthalmitis. Infect Immun. 1999;67(7):3348-56.

133. Forster RK. Experimental postoperative endophthalmitis. Trans Am Ophthalmol Soc. 1992;90(8823):505-59.

134. Ferroni A, Suarez S, Beretti J-L, Dauphin B, Bille E, Meyer J, Bougnoux ME, Alanio A, Berche P, Nassif X. Real-time identification of bacteria and Candida species in positive blood culture broths by matrix-assisted laser desorption ionization-time of flight mass spectrometry. J Clin Microbiol. 2010;48(5):1542-8.

135. Moussaoui W, Jaulhac B, Hoffmann AM, Ludes B, Kostrzewa M, Riegel P, Prévost G. Matrix-assisted laser desorption ionization time-of-flight mass spectrometry identifies $90 \%$ of bacteria directly from blood culture vials. Clin Microbiol Infect. 2010;16(11):1631-8.

136. Prod'Hom G, Bizzini A, Durussel C, Bille J, Greub G. Matrix-assisted laser desorption ionization-time of flight mass spectrometry for direct bacterial identification From positive blood culture pellets. J Clin Microbiol. 2010;48(4):1481-3.

137. Zhou M, Yang Q, Kudinha T, Sun L, Zhang R, Liu C, Yu S, Xiao M, Kong F, Zhao Y, Xu YC. An improved in-house MALDI-TOF MS protocol for direct cost-effective identification of pathogens from blood cultures. Front Microbiol. 2017;8:1824. 
138. La Scola B, Raoult D. Direct identification of bacteria in positive blood culture bottles by matrix-assisted laser desorption ionisation time-of-flight mass spectrometry. Bereswill S, editor. PLoS One. 2009;4(11):e8041.

139. Fothergill A, Kasinathan V, Hyman J, Walsh J, Drake T, Wayne Wang YF. Rapid identification of bacteria and yeasts from positive-blood-culture bottles by using a lysis-filtration method and matrix- assisted laser desorption ionization-time of flight mass spectrum analysis with the SARAMIS database. J Clin Microbiol. 2013;51(3):805-9.

140. Jo SJ, Park KG, Han K, Park DJ, Park Y. Direct identification and antimicrobial susceptibility testing of bacteria from positive blood culture bottles by matrix-assisted laser desorption/ionization time-of-flight mass spectrometry and the Vitek 2 System. Ann Lab Med. 2016;36(2):117.

141. Barza M, Han DP, Pavan PR, Doft BH, Wisniewski SR, Wilson LA, Han DP, Kelsey SF. Evaluation of microbiological diagnostic techniques in postoperative endophthalmitis in the endophthalmitis vitrectomy study. Arch Ophthalmol. 1997;115(9):1142-50.

142. Altan T, Acar N, Zapran Z, Unver Y, Yuritaser S, Kuçuksumer Y, Eser I. Acute-onset endophthalmitis after cataract surgery: success of initial therapy, visual outcomes, and related factors. Retina. 2009;29(5):606-12.

143. Chiquet C, Maurin M, Thuret G, Benito Y, Cornut P, Creuzot-Garcher C, Rouberol F, Pechinot A, Lina G, Romanet JP, Bron A, Vandenesch F; French Institutional Endophthalmitis Study (FRIENDS) group. Analysis of diluted vitreous samples from vitrectomy is useful in eyes with severe acute postoperative endophthalmitis. Ophthalmology. 2009;116(12):2437-41.e1. 
144. ESCRS Endophthalmitis Study Group. Prophylaxis of postoperative endophthalmitis following cataract surgery: Results of the ESCRS multicenter study and identification of risk factors. J Cataract Refract Surg. 2007;33(6):978-88.

145. Gower EW, Lindsley K, Tulenko SE, Nanji AA, Leyngold I, Mcdonnell PJ. Perioperative antibiotics for prevention of acute endophthalmitis after cataract surgery. Cochrane Database Syst Rev. 2017;2:CD006364.

146. Bowen RC, Zhou AX, Bondalapati S, Lawyer TW, Snow KB, Evans PR, Bardsley T, McFarland M, Kliethermes M, Shi D, Mamalis CA, Greene T, Rudnisky CJ, Ambati BK. Comparative analysis of the safety and efficacy of intracameral cefuroxime, moxifloxacin and vancomycin at the end of cataract surgery: a meta-analysis. Br J Ophthalmol. 2018;102(9):1268-76.

147. Schwartz SG, Flynn HW, Grzybowski A, Relhan N, Ferris FL. Intracameral antibiotics and cataract surgery: endophthalmitis rates, costs, and stewardship. Ophthalmology. 2016;123(7):1411-3.

148. Garg SJ, Dollin M, Storey P, Pitcher JD, Fang-Yen NH, Vander J, Hsu J, Post-Injection Endophthalmitis Study Team. Microbial spectrum and outcomes of endophthalmitis after intravitreal injection versus pars plana vitrectomy. Retina. 2016;36(2):351-9.

149. Garg SJ, Dollin M, Hsu J, Storey P, Vander JF. Effect of a strict 'no-talking' policy during intravitreal injection on post-injection endophthalmitis. Ophthalmic Surg Lasers Imaging Retina. 2015;46(10):1028-34.

150. Bjerrum SS, la Cour M. 59 eyes with endogenous endophthalmitis-causes, outcomes and mortality in a Danish population between 2000 and 2016. Graefe's Arch Clin Exp Ophthalmol. 2017 8;255(10):2023-7. 
151. Pinna A, Usai D, Sechi LA, Zanetti S, Jesudasan NCA, Thomas PA, Kaliamurthy J. An outbreak of post-cataract surgery endophthalmitis caused by Pseudomonas aeruginosa. Ophthalmology. 2009;116(12):2321-6.e1-4.

152. Kurniawan ED, Rocke JR, Sandhu SS, Allen PJ. Predictors of visual outcome and the role of early vitrectomy in streptococcal endophthalmitis. Clin Exp Ophthalmol. 2018;46(4):424-31.

153. Falavarjani KG, Alemzadeh SA, Habibi A, Hadavandkhani A, Askari S, Pourhabibi A. Pseudomonas aeruginosa Endophthalmitis: Clinical Outcomes and Antibiotic Susceptibilities. Ocul Immunol Inflamm. 2017;25(3):377-81.

154. Kuriyan AE, Sridhar J, Flynn HW, Smiddy WE, Albini TA, Berrocal AM, Forster RK, Belin PJ, Miller D. Endophthalmitis caused by enterococcus faecalis: Clinical features, antibiotic sensitivities, and outcomes. Am J Ophthalmol. 2014;158(5):1018-23.e1.

155. Aderman CM, Chao DL, Obeid A, Schwartz DM, Bhisitkul RB, Chiu CS. Bilateral enterococcus faecalis endophthalmitis with multiple recurrences. Retin Cases Brief Rep. 2018;Feb 27.

156. Relhan N, Albini TA, Pathengay A, Kuriyan AE, Miller D, Flynn HW. Endophthalmitis caused by Gram-positive organisms with reduced vancomycin susceptibility: literature review and options for treatment. $\mathrm{Br} \mathrm{J}$ Ophthalmol. 2016;100(4):446-52.

157. Deguchi H, Kitazawa K, Kayukawa K, Kondoh E, Fukumoto A, Yamasaki T, Kinoshita S, Sotozono C. The trend of resistance to antibiotics for ocular infection of Staphylococcus aureus, coagulase-negative staphylococci, and Corynebacterium compared with 10-years previous: A retrospective observational study. PLoS One. 2018;13(9):e0203705. 
158. Bispo PJM, Hofling-lima AL, Pignatari ACC. Characterization of ocular methicillin-resistant Staphylococcus epidermidis isolates belonging predominantly to clonal complex 2 subcluster II. J Clin Microbiol. 2014;52(5):1412-7.

159. Asbell PA, Sanfilippo CM, Pillar CM, DeCory HH, Sahm DF, Morris TW. Antibiotic resistance among ocular pathogens in the united states: five-year results from the Antibiotic Resistance Monitoring in Ocular Microorganisms (ARMOR) Surveillance Study. JAMA Ophthalmol. 2015;133(12):1445-54.

160. Vola ME, Moriyama AS, Lisboa R, Vola MM, Hirai FE, Bispo PJM, HoflingLima AL. Prevalence and antibiotic susceptibility of methicillin-resistant Staphylococcus aureus in ocular infections. Arq Bras Oftalmol. 2013;76(6):350-3. 
9 Anexos 


\section{ANEXOS}

\subsection{Aprovação pelo Comitê de Ética Institucional}

HOSPITAL DAS CLINICAS DA
FACULDADE DE MEDICINA DA Plotoforma
USP - HCFMUSP

\section{PARECER CONSUBSTANCIADO DO CEP}

\section{DADOS DO PROJETO DE PESQUISA}

Titulo da Pesquisa: Identificação dos agentes etiologicos nas endoftalmites: cultura convencional, reação em cadeia da polimerase (PCR) e espectrometria de massa

Pesquisador: JOYCE HISAE YAMAMOTO

Área Temática:

Versão: 2

CAAE: 47914315.7 .0000 .0068

Instituição Proponente: HOSPITAL DAS CLINICAS DA FACULDADE DE MEDICINA DA U S P

Patrocinador Principal: FUNDACAO DE AMPARO A PESQUISA DO ESTADO DE SAO PAULO

DADOS DO PARECER

Nümero do Parecer: 1.232 .631

Apresentação do Projeto:

Endoftalmites infecciosas apresentam prognostico visual reservado a depender, principalmente, de um diagnóstico etiológico preciso e rápido e da instituiçāo de tratamento adequado. $O$ isolamento e identificaçāo do agente etiologico pela microbiologia convencional apresentam como principal desvantagem o tempo de alguns dias necessário para um resultado definitivo. Desta forma, a busca por técnicas que proporcionem diagnóstico rápido com alta sensibilidade e especificidade se faz necessaria.

Objetivo da Pesquisa:

1.Implementar a tecnologia de PCR em tempo real no diagnostico das endoftalmites bacterianas e fungicas incluindo o sequenciamento do patógeno;

2.Implementar a tecnologia de espectrometria de massa no diagnostico das endoftalmites bacterianas e fungicas;

3.Comparar os resultados obtidos com os diferentes métodos.

Avaliação dos Riscos e Benefícios:

Não existem riscos esperados neste estudo. Não há beneficio direto ou compensação financeira aos participantes do estudo.






\section{t. \\ HOSPITAL DAS CLIINICAS DA \\ FACULDADE DE MEDICINA DA USP - HCFMUSP}

Continuação do Parecer: 1.232 .631

Comentários e Considerações sobre a Pesquisa:

TCLE - refeita com as orientaçōes - direcionada ao paciente

Considerações sobre os Termos de apresentação obrigatória:

Adequados

Recomendações:

Conclusões ou Pendencias e Lista de Inadequações:

Projeto pronto para ser desenvolvido sem pendéncias

Considerações Finais a critério do CEP:

Em conformidade com a Resoluçāo CNS $n^{\circ} 466 / 12$ - cabe ao pesquisador: a) desenvolver o projeto conforme delineado; b) elaborar e apresentar relatórios parciais e final; c)apresentar dados solicitados pelo CEP, a qualquer momento; d) manter em arquivo sob sua guarda, por 5 anos da pesquisa, contendo fichas individuais e todos os demais documentos recomendados pelo CEP; e) encaminhar os resultados para publicação, com os devidos créditos aos pesquisadores associados e ao pessoal técnico participante do projeto; f) justificar perante ao CEP interrupção do projeto ou a não publicação dos resultados.

Este parecer foi elaborado baseado nos documentos abaixo relacionados:

\begin{tabular}{|c|c|c|c|c|}
\hline Tipo Dacumento & Arquivo & Postagem & Autor & Situaçāo \\
\hline $\begin{array}{l}\text { Projeto Detalhado / } \\
\text { Brochura } \\
\text { Investigador }\end{array}$ & $\begin{array}{l}\text { Protocolo Endoftalmite x PCR x } \\
\text { Espectometria de massa versão } 1606 \\
\text { 2015.doc }\end{array}$ & $\begin{array}{c}22 / 07 / 2015 \\
11: 04: 36\end{array}$ & & Aceito \\
\hline $\begin{array}{l}\text { TCLE / Termos de } \\
\text { Assentimento / } \\
\text { Justificativa de } \\
\text { Ausencia }\end{array}$ & $\begin{array}{l}\text { TCLE Protocolo Endoftalmite x PCR x } \\
\text { Espectometria de massa versão } 1606 \\
\text { 2015.doc }\end{array}$ & $\begin{array}{c}22 / 07 / 2015 \\
11: 04: 44\end{array}$ & & Aceito \\
\hline Outros & $\begin{array}{l}\text { Offcio } 275 \text { Aprovação Conselho } \\
\text { Depto.Oftalmologia.pdf }\end{array}$ & $\begin{array}{c}22 / 07 / 2015 \\
11: 05: 35\end{array}$ & & Aceito \\
\hline Outros & Cadastro Cappesq Registro 13840.pdf & $\begin{array}{c}22 / 07 / 2015 \\
11: 05: 58\end{array}$ & & Aceito \\
\hline Outros & $\begin{array}{l}\text { ANUENCIA LABORATORIO } \\
\text { CENTRAL.pdf }\end{array}$ & $\begin{array}{c}04 / 08 / 2015 \\
17: 56: 14\end{array}$ & & Aceito \\
\hline Folha de Rosto & $\begin{array}{l}\text { FR Protocolo Registro } 13840 \\
\text { reformulada.pdf }\end{array}$ & $\begin{array}{c}04 / 08 / 2015 \\
17: 55: 46\end{array}$ & & Aceito \\
\hline Outros & $\begin{array}{l}\text { Carta_CAPPESQ_Resposta_Parecer_1 } \\
009 \text { 2015.pdf }\end{array}$ & $\begin{array}{c}14 / 09 / 2015 \\
10: 44: 28 \\
\end{array}$ & $\begin{array}{l}\text { JOYCE HISAE } \\
\text { YAMAMOTO }\end{array}$ & Aceito \\
\hline $\begin{array}{l}\text { TCLE / Termos de } \\
\text { Assentimento / }\end{array}$ & $\begin{array}{l}\text { TCLE_Protocolo_Endoftalmite10_09_20 } \\
\text { 15.doc }\end{array}$ & $\begin{array}{c}14 / 09 / 2015 \\
10: 51: 18\end{array}$ & $\begin{array}{l}\text { JOYCE HISAE } \\
\text { YAMAMOTO }\end{array}$ & Aceito \\
\hline
\end{tabular}

Endereço: Rua Ovidio Pires de Campos, $2255^{\circ}$ andar

Bairro: Cerqueira Cesar CEP: 05.403-010

UF: SP

Telefone: (11)2661-7585 Fax: (11)2661-7585 E-mail: cappesq.adm@hc.fm.usp.br 


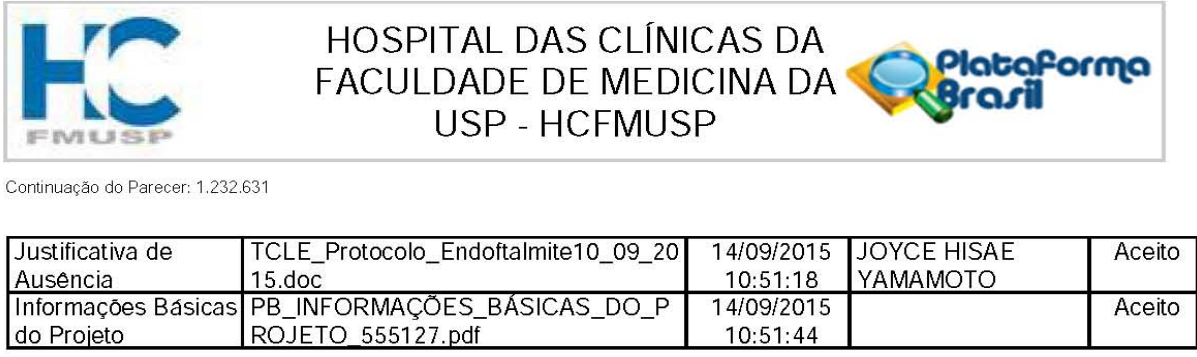

Situação do Parecer:

Aprovado

Necessita Apreciação da CONEP:

Não

SAO PAULO, 17 de Setembro de 2015

Assinado por:

ALFREDO JOSE MANSUR

(Coordenador)

Endereço: Rua Ovídio Pires de Campos, $2255^{\circ}$ andar

Bairro: Cerqueira Cesar
UF: SP $\quad$ Município: SAO PAULO

Telefone: (11)2661-7585 Fax: (11)2661-7585 E-mail: cappesq.adm@hc.fm.usp.br 
9.2 Termo de Consentimento Livre e Esclarecido

\section{HOSPITAL DAS CLÍNICAS DA FACULDADE DE MEDICINA DA} UNIVERSIDADE DE SÁO PAULO-HCFMUSP

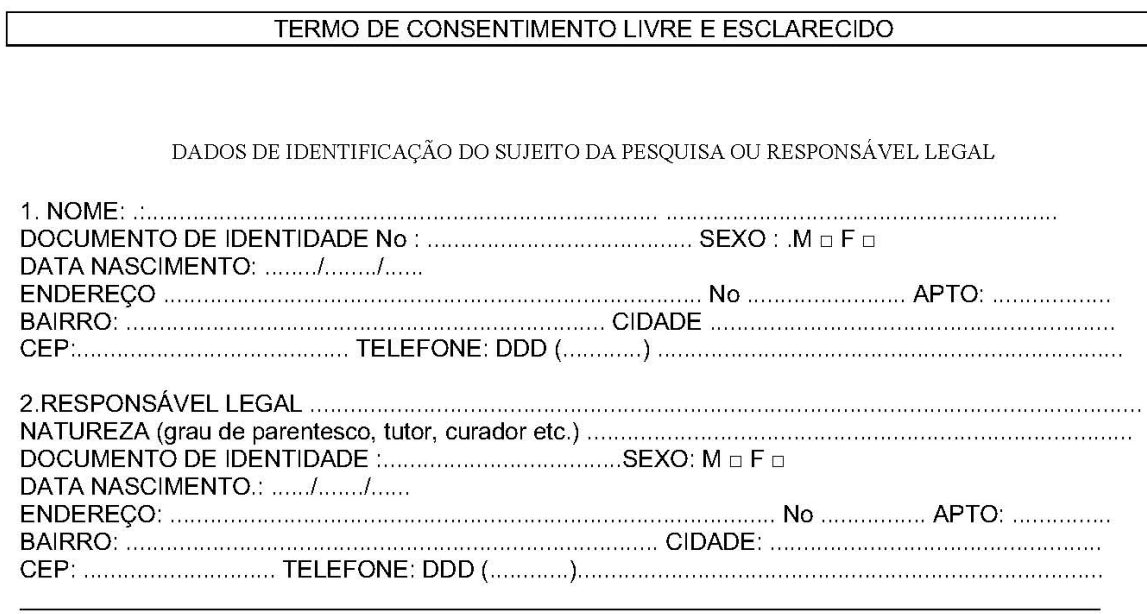

DADOS SOBRE A PESQUISA

1. TÍTULO DO PROTOCOLO DE PESQUISA : "Identificação dos agentes causadores de endoftalmite: cultura, PCR e espectrometria de massa"

PESQUISADOR RESPONSÁVEL: Dra. Joyce Hisae Yamamoto Takiuti

CARGO/FUNÇÃO: Professora Colaboradora FMUSP CRM No 51.804

UNIDADE DO HCFMUSP: Depto. Oftalmologia HCFMUSP

3. AVALIAÇÃO DO RISCO DA PESQUISA:

RISCO MÍNIMO X RISCO MÉDIO

RISCO BAIXO $\square \quad$ RISCO MAIOR

4.DURAÇÃO DA PESQUISA : 24 meses 
HOSPITAL DAS CLINICAS DA FACULDADE DE MEDICINA DA UNIVERSIDADE DE SÃO PAULO-HCFMUSP

1.Justificativa e os objetivos da pesquisa:

O senhor(a) está sendo convidado a participar de uma pesquisa para avaliar os métodos de identificação de bactérias causadoras de infecção dos olhos. Há suspeita de que a inflamação atual no seu olho seja causada por uma infecção. Assim, os exames que serão realizados ajudarão a esclarecer se a inflamação no olho é causada por uma bactéria ou não. O material coletado do seu olho será analisado através de três métodos, sendo que os novos métodos podem ter resultados mais rápidos e mais precisos do que os métodos usuais. Com um resultado mais rápido e preciso, pode-se tratar de forma mais efetiva.

Leia cuidadosamente este termo de consentimento livre e esclarecido e faça todas as perguntas que quiser antes de decidir se quer participar do estudo. Sua decisão de consentir em participar deste estudo é voluntária e o $\operatorname{sr}(a)$ pode sair do estudo a qualquer momento. Se decidir não participar ou retirar-se do estudo, o $\operatorname{sr}(a)$ não perderá os benefícios a que teria direito.

O objetivo desta pesquisa é avaliar o melhor método para identificar os agentes causadores de infecção ocular.

2. Procedimentos que serão utilizados e propósitos, incluindo a identificação dos procedimentos que serão aplicados:

Se você concordar em participar da pesquisa e assinar este termo de consentimento, realizaremos a análise do material coletado no Laboratório Central do Hospital das Clínicas da Faculdade de Medicina da Universidade de São Paulo. Estes dados serão utilizados somente para fins científicos.

Nos pacientes em que o médico suspeita de endoftalmite, ou seja , de infecção ocular, para o tratamento é importante identificar se há um microrganismo causador e identifica-lo. Quando ocorre a suspeita de infecção é importante realizar a coleta de material intraocular antes de iniciar tratamento com antibiótico. A coleta do material é realizada pelo mesmo local em que se realizará o tratamento com aplicação de antibiótico. O material coletado faz parte da rotina atual. Porém, visando a melhora da identificação dos agentes infecciosos, se decidir participar do estudo, avaliaremos o mesmo material coletado por 3 métodos diferentes.

Os exames a serem realizados são laboratoriais; já utilizados, em parte, na prática oftalmológica; e, não vão interferir no tratamento realizado pelo seu médico. O material coletado pelo seu médico oftalmologista será analisado do seguinte modo:

1) Cultura em meios de cultura apropriados para crescimento e identificação do microrganismos.

2) Reação de polimerase em cadeia ( $P C R$ ): trata-se de método de biologia molecular. Parte do materia coletado será analisada por esse método que identifica a presença ou não de DNA bacteriano. Se o resultado for positivo, o material será encaminhado para ser seqüenciado. Por este método identifica-se toda a sequëncia de DNA do microrganismo e compara-se com um banco de dados públicos para se identificar com detalhe qual é este microrganismo

3) Espectometria de massa: os casos que apresentarem positivos na parte inicial do item 1, vão ser analisados por espectrometria de massa (avalia o peso molecular do organismo causador da infecção, compara este resultado com um banco de dados, e identifica-se qual é o microrganismo).

3. Procedimentos rotineiros

Coleta do material ocular será feito durante tratamento realizado pelo médico que indicou o tratamento com injeção de antibiótico devido a suspeita de infecção. A coleta não interfere na conduta a ser TCLE Protocolo Parâmetros clínicos da superficie ocular e citologia de impressão conjuntival X pacientes em tratamento sistêmico com medicaçós imunobiológicas versáo 220914 
realizada e será realizada da mesma forma ,se você participar ou não do estudo. A mudança é apenas na análise do material que incluiremos métodos para avaliar e o local da análise. Caso não participe do estudo, a análise ficará sob responsabilidade do local em que está realizando o tratamento

4. Há desconfortos e riscos esperados:

Não existem riscos esperados neste estudo. Todos os exames a serem realizados já fazem parte da pratica oftalmológica internacional e não interfere na programação do seu tratamento.

5. Benefícios que poderão ser obtidos:

Não há benefício direto ou compensação financeira aos participantes do estudo. Esse estudo poderá ajudar na detecção dos microorganismos causadores de infecção ocular. Isso pode ajudar no entendimento da doença e no desenvolvimento de futuros tratamentos.

6. Procedimentos alternativos que possam ser vantajosos para o senhor(a): não haverá procedimento alternativo.

HOSPITAL DAS CLINICAS DA FACULDADE DE MEDICINA DA UNIVERSIDADE DE SÃO PAULO-HCFMUSP

7. Garantia de acesso: em qualquer etapa do estudo, o sr(a) terá acesso aos profissionais responsáveis pela pesquisa para esclarecimento de eventuais dúvidas. O principal investigador é o Prof Dra Joyce Hisae Yamamoto Takiuti e a Pesquisadora Executante é a Dra. Tatiana Tanaka que pode ser encontrado no endereço Av. Dr Eneas de Carvalho Aguiar, 255, $6^{\circ}$ andar, Ambulatório de Oftalmologia, Telefone(s):2661-6287. Se o sr(a) tiver alguma consideração ou dúvida sobre a ética da pesquisa, entre em contato com o Comite de Ética em Pesquisa (CEP) - Rua Ovídio Pires de Campos, 225 - 50 andar tel: 2661-6442 ramais 16,17, 18 FAX: 2661-6442 ramal 26 -e-mail: cappesq.adm@hc.fm.usp.br.

8. $\mathrm{O} \operatorname{sr}(\mathrm{a})$ tem garantida a liberdade da retirada do consentimento a qualquer momento e deixar de participar do estudo, sem qualquer prejuízo à continuidade de seu tratamento na Instituição.

9. Direito de confidencialidade - As informações obtidas serão analisadas em conjunto com as informações de outros pacientes, não sendo divulgado a identificação de nenhum paciente;

10. O sr(a) tem o direito de ser mantido(a) atualizado(a) sobre os resultados parciais das pesquisas, quando em estudos abertos, ou de resultados que sejam do conhecimento dos pesquisadores;

11. Os dados e o material coletado serão utilizados somente para esta pesquisa

12. O sr(a) não terá despesas pessoais em qualquer fase do estudo, incluindo exames e consultas Também não há compensação financeira relacionada à sua participação. Se existir qualquer despesa adicional, ela será absorvida pelo orçamento da pesquisa.

Acredito ter sido suficientemente informado a respeito das informações que li ou que foram lidas para mim, descrevendo o estudo "Avaliação dos agentes causadores de endoftalmite: cultura, PCR e espectrometria de massa"

Eu discuti com a Dra. Tatiana Tanaka sobre a minha decisão em participar nesse estudo. Ficaram claros para mim quais são os propósitos do estudo, os procedimentos a serem realizados, seus desconfortos e riscos, as garantias de confidencialidade e de esclarecimentos permanentes. Ficou claro também que minha participação é isenta de despesas e que tenho garantia do acesso a tratamento hospitalar quando necessário. Concordo voluntariamente em participar deste estudo e poderei retirar o meu consentimento a qualquer momento, antes ou durante o mesmo, sem penalidades ou prejuízo ou perda de qualquer benefício que eu possa ter adquirido, ou no meu atendimento neste Serviço. 
Assinatura do paciente/representante legal

Assinatura da testemunha
Data

Data ata

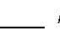

para casos de pacientes menores de 18 anos, analfabetos, semi-analfabetos ou portadores de deficiência auditiva ou visual.

Declaro que obtive de forma apropriada e voluntária o Consentimento Livre e Esclarecido deste paciente ou representante legal para a participação neste estudo.

Assinatura do responsável pelo estudo

Data ' 


\subsection{Publicação: Diagnostic Microbiology and Infection Disease em 2017}

\begin{tabular}{cc}
\hline Contents lists available at ScienceDirect \\
ELSEVIER & Diagnostic Microbiology and Infectious Disease \\
\hline iournal homepage: www.elsevier.com/locate/diagmicrobio
\end{tabular}

Bactec $^{\mathrm{TM}}$ blood culture bottles allied to MALDI-TOF mass spectrometry: rapid etiologic diagnosis of bacterial endophthalmitis

Tatiana Tanaka a,*, Luiza Manhezi de Freitas Oliveira ${ }^{a}$, Bruno Fortaleza de Aquino Ferreira ${ }^{a}$, Juliana Mika Kato ${ }^{\text {a }}$, Flavia Rossi ${ }^{\mathrm{b}}$, Karoline de Lemes Giuntini Correa ${ }^{\mathrm{b}}$, Sergio Luis Gianotti Pimentel ${ }^{\mathrm{a}}$,

Joyce Hisae Yamamoto a , João Nóbrega Almeida Junior ${ }^{\mathrm{b}, \mathrm{c}}$

${ }^{2}$ Department of Ophthalmology, Hospital das Clinicas, University of Sao Pauto (USP), 255, Dr Enéas de Carvalho Aguiar Averue - 6th foor, Sac Paulo, Brazil ${ }^{b}$ Centrai Laboratory Division LIMO3, Hospital das Chinicas, University of Sä Paulo (USP), 255, Dr Enéas de Carvallo Aguiar Avenue - 6th floot, Sao Paulo, Brazil ${ }^{2}$ institute of Tropical Medicine-LIM53, University of Sao Fauto (USP), 255, Dr Enéas de Carvalho Agular Avenue - 6th floor, Sao Faulo, Brazil

\begin{tabular}{l} 
A R T I C L E I N F O \\
\hline Article history: \\
Received 20 December 2016 \\
Received in revised form 22 March 2017 \\
Accepted 19 April 2017 \\
Available online 26 April 2017 \\
\hline Keywords: \\
Endophthalmitis \\
MALDI-TOF mass spectrometry \\
Diagnosis \\
Blood culture bottle
\end{tabular}

A B S T R A C T

Matrix-assisted laser desorption ionization-time of flight (MALDI-TOF) mass spectrometry (MS) has been used for direct identification of pathogens from blood-inoculated blood culture bottles (BCBs). We showed that ndophthalmitis fron vitreous humor-inoculated BCBs with a simple protocol.

Endophthalmitis is a rare and severe intraocular infection (Ben Artsi et al., 2016). Rapid etiologic diagnosis and adequate antimicrobial therapy may preclude evisceration or enucleation (Lu et al., 2016)

For etiologic diagnosis of endophthalmitis, direct inoculation of blood culture bottles (BCBs) with humor vitreous has been a suitable alternative for small amount samples with higher sensitivity, compared to direct inoculation on solid media (Tan et al., 2011). However, the standard identification (ID) of pathogens grown in BCBs requires agar medium subculture, which delays the final result (Clark et al, 2013). Although molectilnogen from poitive boodchtures, high cost per assay remains a limiting factor for large-scale implementation of these technologies in clinical laboratories (Opota et al., 2015). Matrix-assisted laser desorption ionization-time of flight (MALDI-TOF) mass spectrometry (MS) represents a revolution for rapid and precise pathogen ID in clinical laboratories (Clark et al., 2013). Moreover, MALDI-TOF MS has been applied for direct pathogen ID from positive BCBs, substantially reducing turnaround time (TAT) for microorganism ID with lower costs per assay (Verroken et al, 2016). There is a lack of studies using MALDI-TOF MS etiologic diagnosis of bacterial endophthalmitis. Therefore, we describe

* Corresponding author. Tel.: + 55-11-99607-9335; fax: +55-11-4613-6008. E-mail cidtress: tatitanaka91@gmail.com (T. Tanaka).

ttpp://dxdoi.org/10.1016/j.diagmicrobio.2017.04.008 0732-8893/0 2017 Elsevier Inc. All rights reserved.
MALDI-TOF MS for direct bacterial ID in BCBs inoculated with vitreous humor, applying a simple in-house protocol.

This prospective study, conducted at Hospital das Clínicas from the University of Sao Paulo, included patients with clinical suspicion of endophthalmitis from October 2015 to November 2016.

Vitreous samples obtained after vitreous biopsy or vitrectomy were inoculated in BCBs (Bactec Pediatric Plus, Becton Dickinson and $\mathrm{Co}, \mathrm{BD}, \mathrm{N}$, USA) and incubated in the Bactec FX system ${ }^{\mathrm{TM}}$ (BD) at $35^{\circ} \mathrm{C}$ for five days. Positive BCBs were seeded in culture plates according to standard procePorive (Jot B a posive BCBs were, al iquots from positive BCBs were submitted for a three-step protein extraction protocol (Video 1) for direct ID by MALDI-TO MS: a) a $4 \mathrm{ml}$ aliquot was transferred to a serum separation tub (Vacutainer ${ }^{B}$ STTM, Becton, Dickinson and $\mathrm{Co}$.) and centrifuged $(2.500 \mathrm{rpm}, 15 \mathrm{~min}) ;$ b) supernatant was discarded, and pellet was washed with $1 \mathrm{ml}$ of deionized water and centrifuged $(13,000 \mathrm{rpm}$, $2 \mathrm{~min}$ ); c) supernatant was discarded again, and $1 \mu \mathrm{l}$ of the remaining pellet was spotted on MALDI-TOF MS target plate and overlaid with 1 th of $\alpha$-cyano-4-hydroxycinnamic acid matrix. Microorganism 1

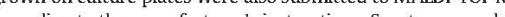
econt at analyzed by the Vitek MS system equipped with in vitro diagnosti (IVD) database v3.2 (bioMérieux, Marcy-l'Etoile, France). Final microorganisms' ID and TAT of both protocols (direct and grown in plates) were compared. TAT for positive blood cultures processing and reporting was 
considered the sum of the time to positivity necessary for microorganism growth during BACTEC FX incubation (equal for both methods) and time from bottle positivity to finat species ID. Statistical analysis was caried out using Mann-Whitney non-parametric test. $P \leq 0.05$ was considered statistically significant.

Forty-one samples of vitreous humor from 31 patients were analyzed (Table 1). Endophthalmitis cases were mainly associated with phacoemulsification $(n=11)$ and trauma $(n=4)$. The most prevalent agents were Staphylococcus spp. (41.4\%).

Thirty-seven of 41 positive BCBs ( $90.2 \%$ ) had correct species ID by direct MALDI-TOF MS analysis. Among 35 samples with Gram-positive pathogens, 31 (88.5\%) had correct species ID by direct MALDI-TOF MS analysis. All samples with Gram-negative pathogens $(\mathrm{n}=6)$ had correct species ID by direct MALDI-TOF MS analysis.

Median TAT for pathogen identification by standard culture methor and direct MALDI-TOF MS analysis from BCBs was $43.9 \mathrm{~h}$ and $14.4 \mathrm{~h}$, respectively (Fig. 1) $(P<0.001)$. Median TAT reduction for pathogen identification by direct MALDI-TOF MS analysis was $31.7 \mathrm{~h}$ and $26 \mathrm{~h}$ for samples with Gram-positive and Gram-negative bacteria, respectively $(\mathrm{p}=0.3)$.

MALDI-TOF MS has been recently used for identification of microorganisms directly from positive blood-inoculated $\mathrm{BCBS}$, with some studies showing identification rates of $80 \%$ to $90 \%$ when compared to ID after subcultures on solid medium (Buchan et al., 2012; Jakovljev and Beroh,
2015; Lagacé-Wiens, 2015). However, blood cells and serum proteins interfere with MALDI-TOF analysis, making washing steps necessary to obtain a species-specific spectral profile (Spanu et al., 2012). Conversely, proteins and cellular elements are scarce in the vitreous humor, which might have contributed to the good performance of our simple in-house three-step protein extraction protocol for direct pathogen ID by MALDI-TOF MS.

Expressive reduction of TAT for pathogen ID by rapid diagnostic tests, such as MALDI-TOF MS, allied to antimicrobial stewardship have been shown to reduce the duration of unnecessary antimicrobial therapy and to decrease the time to clinical response in bloodstream infections (Carreno et al 2016) Some authors described ID TAT reduction of more than three days Cor Gram-positive bacteria Trown (Buchan (Buchan etal, 2012). TOF MS analysis when compared to ID after subcultures on solid plates. Although it was not evaluated in our study, patient outcomes may also be improved in cases of endophthalmitis. Rapid ID of species with intrinsic antimicrobial resistance or high virulent pathogens may lead to a faster prescription of the best-targeted therapy or even to a more aggressive approach, such as pars plana vitrectomy for infections caused by $S$, aureus or $S$. pneumoniae.

Despite rapid ID results by direct MALDI-TOF MS seems to be promising subcultures remain necessary when initial analysis fails to provide

Pathogen identification and turnaround time for final result of forty-one positive vitreous-inoculated blood culture bottles samples from 31 patients.

\begin{tabular}{|c|c|c|c|c|c|c|}
\hline Patient & Sample No. & Sample Type & Source of infection & Agent & $\begin{array}{l}\text { TATd ID }^{\mathrm{b}} \text { after } \\
\text { subculture (hours) }\end{array}$ & $\begin{array}{l}\text { TAT ID by direct } \\
\text { MAIDI-TOF } \\
\text { analysis (hours) }\end{array}$ \\
\hline 1 & 1 & Vitreous biopsy & Endogenous & Staphylococtus aureus & 33.2 & 10.6 \\
\hline 2 & 2 & Vitrectomy & Trauma & S. aureus & 43.9 & 4.1 \\
\hline 3 & 3 & Vitrectomy & Trauma & 5. aureus & 53.1 & 21.4 \\
\hline \multirow[t]{2}{*}{4} & 4 & Vitrectomy & Endogenous & S. aureus & 34.9 & 14.7 \\
\hline & $\begin{array}{l}4 \\
5\end{array}$ & Vitrectomy ${ }^{4}$ & & 5. aureus & 34.9 & 19.2 \\
\hline 5 & 6 & Vitreous biopsy & Intravitreal bevacizumab injection & 5. aureus & 51.9 & 14.4 \\
\hline \multirow[t]{3}{*}{6} & 7 & Vitreous biopsy & Endogenous & S. aureus & 28.9 & 8.7 \\
\hline & 8 & vitrectomy ${ }^{A}$ & & 5. aureus & 44.8 & 22.4 \\
\hline & 9 & Vitrectomy $^{d, e}$ & & 5. aureus & 44.6 & 15.1 \\
\hline 7 & 10 & Vitreous biopsy & Intravitreal triamcinonole injection & Staphylococcus epidermidis & 58.6 & 23.8 \\
\hline \multirow[t]{2}{*}{8} & 11 & $\begin{array}{l}\text { Vitrectomy } \\
\text { sy }\end{array}$ & Extracapsular cataract extraction & 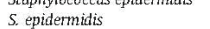 & 59.1 & 24.7 \\
\hline & 12 & vitrectomy ${ }^{z}$ & & 5. epidermidis & 60.9 & 26.6 \\
\hline 9 & 13 & Vitreous biopsy & Suture removal & S. epidermidis & 55.9 & 25.9 \\
\hline 10 & 14 & $\begin{array}{l}\text { Vitreous biopsy } \\
\text { Vis }\end{array}$ & Phacoemulsification & 5. epidermidis & 56.5 & 21.3 \\
\hline 11 & 15 & Vitreous biopsy & Phacoemulsification & S. epidermidis & 52.1 & 18.5 \\
\hline 12 & 16 & Vitrectomy & Phacoemulsification & S. epidermidis & 63.1 & Not identified \\
\hline 13 & 17 & Vitreous biopsy & Phacoemulsification & S. epidermidis & 50.9 & 19.6 \\
\hline \multirow[t]{2}{*}{14} & 18 & Vitrectomy & Phacoemul sification & Staphylococous themolyticus & 38.8 & 12.6 \\
\hline & 19 & Vitrectomy $y^{a}$ & & $\begin{array}{l}\text { 5. Fremolyticus } \\
\text { s. }\end{array}$ & 59.5 & 14.9 \\
\hline 15 & 20 & Vitrectomy & Intravitreal bevacizumab injection & S. haemolyticus & 130.3 & 21.1 \\
\hline \multirow[t]{2}{*}{16} & 21 & Vitrectomy & Phacoemulsification & Staphyloccocus Tugdunensis & 60.5 & 19.6 \\
\hline & 22 & Vitrectomy $y^{2}$ & & 5. lugdunensis & 60.5 & 20.1 \\
\hline 17 & 23 & Vitreous biopsy & Phacoemulsification & Streptococcus pnetumonicie & 36.8 & 4.4 \\
\hline 18 & 24 & Vitreous biopsy & Pars plane vitrectomy & S. pneumoniae & 34.7 & 8.0 \\
\hline 19 & 25 & Vitreous biopsy & Suture removal & S. pneumoniae & 35.0 & 3.9 \\
\hline 20 & 26 & $\begin{array}{l}\text { Vitreous biopsy } \\
\text {. }\end{array}$ & Trabeculectomy & S. pneumoniae & 29.1 & 9.3 \\
\hline 21 & 27 & Vitrectomy & Extracapsular cataract extraction & S. pneumoniae & 34.7 & Not identified \\
\hline \multirow[t]{3}{*}{22} & 28 & Vitreous biopsy & Trauma & VGS $S^{c}$ & 41.1 & 3.9 \\
\hline & 29 & Vitrectomy $y^{\mathrm{s}}$ & & VGS & 50.5 & 13.6 \\
\hline & 30 & Vitrectomy $y^{\mathrm{d}, \mathrm{e}}$ & & VGS & 41.1 & 13.1 \\
\hline 23 & 31 & Vitreous biopsy & Phacoemulsification & VGS & 27.7 & Not identified \\
\hline 24 & 32 & Vitrectomy & Extracapsular cataract extraction & Abiotrophia & 187.5 & 94.0 \\
\hline 25 & 33 & Vitreous biopsy & Phacoemulsification & Abiotrophia & 76.8 & Not identified \\
\hline \multirow[t]{2}{*}{26} & 34 & Vitrectomy & Phacoemulsification & Bacilitus $s p$ & 36.7 & 10.0 \\
\hline & 35 & Vitrectomy ${ }^{*}$ & & Bacilius sp & 36.7 & 12.1 \\
\hline 27 & 36 & Vitrectomy & Trabeculectomy & Hoemophitus infuenzoe & 63.5 & $\begin{array}{l}1.1 \\
15.6\end{array}$ \\
\hline \multirow{2}{*}{28} & 37 & Vitrectomy & Phacoemulsification & Pseudomonas aeruginosa & 35.1 & 13.2 \\
\hline & 38 & Vitrectomy ${ }^{e}$ & & P. aeruginosa & 35.1 & 13.6 \\
\hline 29 & $\begin{array}{l}30 \\
39\end{array}$ & Vitreous biopsy & Suture removal & $\begin{array}{l}\text { 5. marcencens } \\
\text { 5. }\end{array}$ & 38.1 & 12.6 \\
\hline 30 & 40 & Vitreous biopsy & Trauma & 5. marcencens & 33.5 & 7.0 \\
\hline 31 & 41 & Vitreous biopsy & Trabeculectomy & S. marcencens & 37.2 & 3.1 \\
\hline
\end{tabular}




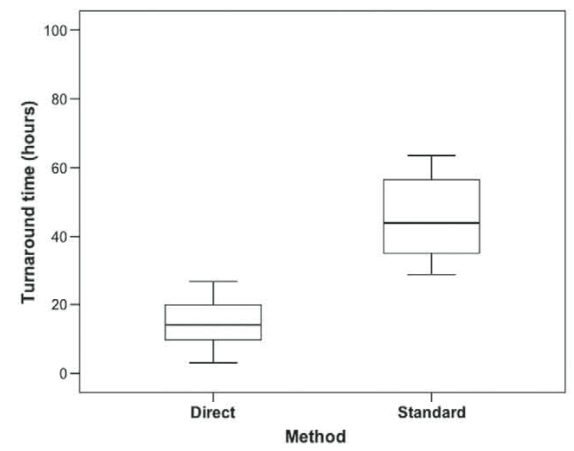

Fig. 1. Box-and-Whiskers plot of the turnaround time for pathogen identification according to methodology. Direct: turnaround time for direct pathogen identification
from vitrenus humor-inoculated blood culture bottles by MAIDI-TOF mass from vitrenus humor-inoculated blood culture bottles by MALDI-TOF mas
spectrometry. Standard: turnaround time for pathogen identification after subculture of from blood culture bottles.

species ID or when there is a polymicrobial infection, reported in less than $4 \%$ of all cases of endophthalmitis (Jindal et al., 2013). Moreover, final antimicrobial susceptibility testing can only be achieved with colonies grown on agar plates after subculture.

We concluded that direct ID by MALDI-TOF MS of positive vitreous humor-inoculated BCBs applying a simple protein extraction protocol is a new alternative for clinical laboratories to hasten the etiologic diagnosis of bacterial endophthalmitis.

Supplementary data to this article can be found online at http://dxdoi org/10.1016/j.diagmicrobio.2017.04.008.

\section{Acknowledgements}

Authors declare no conflict of interest
We would like to thank Valeria Teixeira Alves Rosa and Rosilaine Souza Arruda Teberges for the technical assistance.

\section{References} Ben Artsi E, Katz G, Kinori M, Moisseiev J. Endophthalmitis today: a multispecialty oph-
thalmology department perspective. Eur J Ophthalmol 2016;26:71-7. http://dx.doi.

org $/ 10.5301 /$ jojo.5000642.
han BW, Riebe KM, Ledeboer NA. Comparison of the MALDI Biotyper system using Sepsityper specimen processing to routine microbinlogical methods for identification
of bacteria from positive blood culture bottles. J đain Microbiol 2012;50:346-52. http://dx.doinrg/10.1128/CM05021-11.

Carreno II, Lomaes tro BM, Jacobs AL, Meyer RE, Evans A, Montero CI. Assessment of time to clinical response in patients with sepsis treated before and after implementation of a matrix-assisted laser desorption ionization time-d-hight blood culture identifica10.1017/ice.2016.105.
.

Clark AE, Kaleta EJ, Arora A, Wolk DM. Matrix-assisted laser desorption ionization-time of flight mass spectrometry: a fund amental shift in the routine practice of clinical microbiology. Clin Microbiol Rev 2013;26:547-603. http://dx.doi.org/10.1128/CMR.

kovijijev A. Bergh K. Development of a rapid and simplified protocol for direct bacterial identification from positive blood cultures by using matrix assisted laser desorption

JindalA, Moreker MR, Pathengay A, Khera M, Jalali S, Majij A, et al. Polymicrobial endophthalmitis: prevalence, causative organisms, and visual outcomes. J Ophthalmi Inflamm Infect 2013;3:6. http:///dxdoiorg/10.1186/1869-5760-3-6. Man

Iagacé-Wiens P. Matrix-assisted laser desorption/ionization time of flight mass spectrometry (MAIDI-TOF/MS)-based identification of pathogens from positive blood cilture bottle Methods Mol Biol 2015; 237:47-55. hetp://dx.doiorg/0.1007/978-1-4939-1776-1_5.

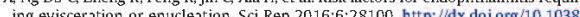
srep28100.

Opota O, Croxat to A, Prod'hom G, Greutb Gr. Bood culture-based diagnosis of bacteraemia state of the art. Clin Microbiol Infect 2015;21:313-22. http://dx.doi.org/10.1016/3 cmi.2015.01.003

B, Fiori B, DInzeo T, Campoli S, RuggeriA, et al Direct maldi-tof mass spectometry assay of blood culture broths for rapid identification of Candida species causing

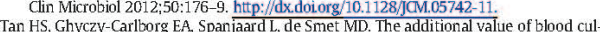
ture tottles in the diagnosis of endophthalmitis. Eye (Lond) 2011;25:1069-73. hetp: ///dx.doi.0rg/10.1038/eye 2011.142

Laterre P-F, Delmée M, et a equate antimicrobial treatment in sensis with nositive blood cultures. PLoS One 2016 11:e0156259. http://dx.doiorg/10.1371/joumal pone0156299. 


\section{Diagnostic value of pediatric blood culture bottles for acute
ORIGINAL ARTICLE postoperative endophthalmitis}

Tatiana Tanaka I,* (D) Bruno Fortaleza de Aquino Ferreira' (D) Luiza Manhezi Shin de Oliveira 1 (D) Juliana Mika Kato,' (D) Thais Sabato Romano Di Gioia," (iD Flavia Rossi," (ID Yoshitaka Nakashima,' (ID) Sergio Luis Gianotti Pimentel,' (D) Joyce Hisae Yamamoto,' (iD) Joao Nobrega de Almeida Junior" (D)

'Departamento de Oftalmologia (LIM 33), Hospital das Clinicas HCFMUSP, Faculdade de Medicina, Universidade de Sao Paulo, Sao Paulo, SP, BR. "Divisao Laboratorio Central (LIM 03), Hospital das Clinicas HCFMUSP, Faculdade de Medicina, Universidade de Sao Paulo, Sao Paulo, SP, BR.

Tanaka T, Ferreira BFA, Oliveira LMS, Kato JM, Gioia TSR, Rossi F, et al. Diagnostic value of pediatric blood culture bottles for acute postoperative endophthalmitis. Clinics. 2019;74:e837

*Corresponding author: E-mail: tatiana.tanaka@hc.fm.usp.br

OBJECTIVE: To report our experience using conventional culture methods (CM) and pediatric blood culture bottles (PBCBs) for vitreous sample culture of acute postoperative endophthalmitis.

METHODS: A retrospective study was conducted at the Department of Ophthalmology, Hospital das Clinicas, HCFMUSP, Faculdade de Medicina, Universidade de Sao Paulo, Sao Paulo, BR, from January 2010 to December 2015, and it included 54 patients with clinically suspected acute postoperative endophthalmitis. Vitreous samples were obtained by vitreous tap or vitrectomy. Samples from January 2010 to December 2011 were cultivated in CM, whereas samples from January 2012 to December 2015 were inoculated in PBCBs. The measured outcome was the yield of positive cultures.

RESULTS: Twenty cases were included in the CM group, and 34 cases were included in the PBCB group. The yield of positive cultures in PBCBs $(64.7 \%)$ was significantly higher than that in conventional CM $(35 \%, p=0.034)$. Staphylococcus epidermidis and Streptococcus viridans were the two most commonly found agents.

CONCLUSION: PBCBs can be used successfully in clinically suspected endophthalmitis. The method showed a higher yield of positive cultures than the conventional method. This technique appears to have several advantages over the traditional method: it saves time, as only one medium needs to be inoculated; transportation to a laboratory is easier than in the traditional method, and there is no need to maintain a supply of fresh agar media. The use of PBCBs may be recommended as the primary method for microbiological diagnosis and is especially suitable for office settings and remote clinics.

KEYWORDS: Endophthalmitis; Conventional Culture; Blood Culture Bottle; Postoperative Complications.

\section{- INTRODUCTION}

Endophthalmitis is a serious intraocular infectious disease ssociated with elective surgical procedures $(75$ to $80 \%$ ), ocula trauma $(3.3$ to $17 \%)$ and endogenous infections $(5-15 \%)(1-3)$ Suspected cases are initially treated with intravitreal injection of Suspected cases are initially treated with intravitreal injection
broad-spectrum antibiotics (vancomycin and ceftazidime) (4). broad-spectrum antibiotics (vancomycin and ceftazidime) (4).
The use of sample cultures is essential to confirming endophthalmitis etiology. Several conditions such as ocula inflammation from noninfectious uveitis, fungal endophthalmitis, and toxic anterior segment syndrome may mimic clinical

Copyright $₫ 2019$ CLINICS - This is an Open Access article distributed under the terms of the Creative Commons License (http://creativecommons.org/licenses/ medium or format, provided the original work is properly cited.

No potential conflict of interest was reported.

Received for publication on May 27, 2018. Accepted for publication

DOI: $10.6061 /$ dinics/2019/e837 presentation of endophthalmitis, but bacterial cultures are negative in these cases (5). Identification of the pathogen in cases of endophthalmitis may improve treatment by the early introduction of targeted antibiotics.

Despite advances in molecular assays for detecting pathogens, microbial culture is still the current reference method for the etiological diagnosis of endophthalmitis. Conventional culture methods (CM) use solid or broth media including thioglycolate. However, rates of identification increase when blood culture bottles (BCBs) are used (3,6-9)

The present study aimed to report our own experience using pediatric $\mathrm{BCBs}(\mathrm{PBCBs})$ and conventional media for vitreous sample culture in acute postoperative endophthalmitis.

\section{- METHODS}

Fifty-four cases of clinically suspected acute postoperative endophthalmitis, attended at the Department of Ophthalmology, endophthalmitis, attended at the Department of Ophthalmology,
Hospital das Clinicas HCFMUSP, Faculdade de Medicina, Hospital das Clinicas HCFMUSP, Faculdade de Medicina,
Universidade de Sao Paulo, Sao Paulo, SP, BR, between January 2010 and December 2015, were retrospectively included. This 
study was approved by the Institutional Ethics Committee (CAAE: 36514614.4.0000.0068).

Undiluted vitreous samples (200 to $500 \mathrm{~mL}$ ) were collected by pars plana vitrectomy or vitreous tap after local antisepsis, under local anesthesia and before intravitreal administration of antibiotics.

From January 2010 to December 2011, samples were cultivated in $\mathrm{CM}$ (thioglycolate) for 5 days at $35^{\circ} \mathrm{C}$. From January 2012 to in CM (hing 2012 to December 2015, samples were inoculated in PBCBs (BACTEC
Plus Aerobic/F, BD Diagnostics, USA) and incubated in automated Plus Aerobic/F, BD Diagnostics, USA) and incubated in automated
machines for up to 5 days. Positive samples from CM or PBCBs machines for up to 5 days. Positive samples from $\mathrm{CM}$ or PBCBs
were later inoculated in sheep blood and chocolate agar and incubated for 48 hours under a $5 \% \mathrm{CO}_{2}$ atmosphere. Identification of causative agents and antibiotic sensitivity tests were performed by VITEK 2 (BioMèrieux, France)

The yields of positive cultures with CM and with $\mathrm{PBCBs}$ were compared by using McNemar's test, and the results were considered statistically significant if the $p$-value was less than $5 \%(p<0.05)$.

\section{RESULTS}

Vitreous samples from 54 patients with endophthalmitis were analyzed. They were associated with phacoemulsification $(\mathrm{n}=21$ $38.9 \%)$, trabeculectomy $(\mathrm{n}=11 ; 20.4 \%)$, extracapsular cataract extraction $(n=6 ; 11.1 \%)$, phacoemulsification combined with trabeculectomy $(\mathrm{n}=5 ; 9.3 \%)$, pars plana vitrectomy $(\mathrm{n}=4 ; 7.4 \%)$, intravitreal bevacizumab injection ( $\mathrm{n}=4 ; 7.4 \%$ ), congenital cataract surgery $(\mathrm{n}=2 ; 3.7 \%)$ and phacoemulsification combined with pars plana vitrectomy $(\mathrm{n}=1 ; 1.8 \%)$

Thirty-five percent ( 7 out of 20 cases) of $\mathrm{CM}$ and $64.7 \%$ (22 out of 34 cases) of $\mathrm{PBCB}$ cultures were positive $(p=0.034)$ (Table 1). Isolated agents from the 29 positive cultures were Staphylococcus epidermidis $(\mathrm{n}=7 ; 24.2 \%)$, Streptococcus viridans $(\mathrm{n}=6 ; 20.9 \%)$, Staphylococcus aureus $(\mathrm{n}=3 ; 10.4 \%)$, Haemophilus influenzae ( $\mathrm{n}=3 ; 10.4 \%$ ), coagulase-negative Staphylococcus $(\mathrm{n}=2$; $6.9 \%)$. Streptococcus pneumoniae $(\mathrm{n}=1 ; 3.4 \%)$, Enterococcus facalis $(\mathrm{n}=1 ; 3.4 \%)$ Pseudomonas aeruginosa $(\mathrm{n}=1 ; 3.4 \%)$ Klebsiella oryloca (n=1;3.4\%), Serratia marcescens ( $(n=1 ; 3.4 \%)$, Staphylococcus lugdunensis $(\mathrm{n}=1 ; 3.4 \%)$, unspecific gram-positive bacilli ( $\mathrm{n}=1 ; 3.4 \%)$ and Enterobacter cloacae $(\mathrm{n}=1 ; 3.44)$. Seventysix percent of the isolates were gram-positive bacteria, mainly Staphylococcus spp. and Streptococcus spp. ( $\mathrm{n}=20 ; 68.9 \%)$. Agents isolated from conventional media or in PBCBs according to the associated procedure are described in Table 2 .

\section{DISCUSSION}

Endophthalmitis is a rare and devastating complication of ocula surgeries. Rapid identification of the pathogen with adequate treatmen may impact visual prognosis. Conventional culture uses solid or broth media; however, PBCBs confer several advantages. Therefore, we demonstrate our experience with using $\mathrm{PBCBs}$ for endophthalmitis.

Conventional methods include the use of blood agar, chocolate agar, Sabouraud agar and thioglycolate broth. They require immediate incubation (not available at all ophthalmologic centers), and endophthalmitis positivity varies widely in the literature, ranging from 24 to $72 \%(3,6-8,10-17)$. These low sensitivities can be explained by various factors such as the small volume of specimens, the use of antibiotics before the collection of clinical material and the presence of fastidious microorganisms causing endophthalmitis (18)

On the other hand, $\mathrm{BCBs}$ confer the possibility of storage at room temperature, microorganism growth with small volume samples, ease of inoculation and low risk of contamination during transport The use of BCBs is a good alternative in cases of endophthalmitis in areas with limited access to a microbiology laboratory. $\mathrm{BCBs}$ also allows the growth of fastidious pathogens (which grow better in atmosheres with high $\mathrm{CO}_{2}$ tension) and contain resin th in ate adscBs an (19). PBCBs have already been accepted as a diagnostic tool for smal samples such as blood in pediatric practice, synovial fluid, pleural fluid and peritoneal fluid (19). Kratz et al. have also used PBCBs to test for infectious keratitis and had promising results. Indeed, in some endophthalmitis studies, PBCBs were used (3). Studies using undiluted vitreous samples and $\mathrm{BCBs}$ showed average positivity varying from $61 \%$ to $100 \%(3,6-9,19-22)$. In contrast, when they used BCBs, likely due to the use of diluted vitreous.

Table 1 - Isolated agents from vitreous samples from patients with acute postoperative endophthalmitis using the conventional method $(\mathrm{CM})$ and pediatric blood culture bottles (PBCBs).

\begin{tabular}{lccc}
\hline Isolated agents & $\mathrm{CM}(\mathbf{n}=7)$ & PBCB (n=22) & Total \\
\hline Staphylococcus epidermidis & 2 & 5 & $7(24.2 \%)$ \\
Streptococcus viridans & 1 & 5 & $6(20.9 \%)$ \\
Staphylococcus aureus & - & 3 & $3(10.4 \%)$ \\
Haemophilus influenzae & - & 3 & $3(10.4 \%)$ \\
Coagulase-negative Staphylococcus & 2 & - & $2(6.9 \%)$ \\
Staphylococcus lugdunensis & - & 1 & $1(3.4 \%)$ \\
Streptococcus pneumoniae & - & 1 & $1(3.4 \%)$ \\
Enterococcus faecalis & - & 1 & $1(3.4 \%)$ \\
Enterobacter cloacae & 1 & - & $1(3.4 \%)$ \\
Pseudomonas aeruginosa & 1 & - & $1(3.4 \%)$ \\
Klebsiella oxytoca & - & 1 & $1(3.4 \%)$ \\
Serratia marcescens & - & 1 & $1(3.4 \%)$ \\
Unspecific gram-positive bacilli & - & 1 & $1(3.4 \%)$ \\
\hline
\end{tabular}


Chiquet et al. compared diluted with undiluted vitreous samples using conventional culture methods and suggested that diluted samples were as effective as undiluted samples for microbiological diagnosis of endophthalmitis, however, they also commented that the small number of positive cultures could preclude improving the understanding of the impact of dilution on culture sensitivity (23).
Comparative studies of $\mathrm{CM}$ and $\mathrm{BCB}$ positivities were carried out in six studies $(3,6-9,22)$; five of them demonstrated a higher positivity with BCBs than with conventional methods (Figure 1) Yospaiboon et al had a cohort of 27 patients and reported low growth rates overall, $51.9 \%$ positivity in BCBs and $25.9 \%$ in the traditional method; as discussed by the authors, these results

Table 2 - Isolated agents according to procedure and use of conventional media or pediatric blood culture bottles (PBCBs).

\begin{tabular}{|c|c|c|c|c|}
\hline Procedure & $\begin{array}{c}\text { Conventional media, } \\
\text { (positive cases, \%) }\end{array}$ & Isolated agent (n) & $\begin{array}{c}\text { PBCB , } n \\
\text { (positive cases, \%) } \\
\end{array}$ & Isolated agent (n) \\
\hline \multirow[t]{5}{*}{ Phacoemulsification } & $9(4,44.4 \%)$ & $\begin{array}{l}\text { Staphylococcus } \\
\text { epidermidis (1) }\end{array}$ & $12(8,66.7 \%)$ & $\begin{array}{l}\text { Staphylococcus } \\
\text { epidermidis (3) }\end{array}$ \\
\hline & & $\begin{array}{l}\text { Coagulase-negative } \\
\text { Staphylococcus (1) }\end{array}$ & & Staphylococcus aureus (1) \\
\hline & & $\begin{array}{l}\text { Pseudomonas aeruginosa } \\
\text { (1) }\end{array}$ & & $\begin{array}{l}\text { Staphylococcus } \\
\text { lugdunensis (1) }\end{array}$ \\
\hline & & Enterobacter cloacae (1) & & Streptococcus viridans (2) \\
\hline & & & & $\begin{array}{l}\text { Unspecific gram-positive } \\
\text { bacilli (1) }\end{array}$ \\
\hline \multirow[t]{2}{*}{$\begin{array}{l}\text { Extracapsular cataract } \\
\text { extraction }\end{array}$} & $2(1,50.0 \%)$ & $\begin{array}{l}\text { Staphylococcus } \\
\text { epidermidis (1) }\end{array}$ & $4(3,75.0 \%)$ & $\begin{array}{l}\text { Staphylococcus aureus (1) } \\
\text { Haemophilus influenzae (1) }\end{array}$ \\
\hline & & & & Klebsiella oxytoca (1) \\
\hline Pars plana vitrectomy & $4(1,25.0 \%)$ & $\begin{array}{l}\text { Coagulase-negative } \\
\text { Staphylococcus (1) }\end{array}$ & $0(0)$ & \\
\hline \multirow[t]{5}{*}{ Trabeculectomy } & $3(0,0 \%)$ & & $8(7,87.5 \%)$ & $\begin{array}{l}\text { Staphylococcus } \\
\text { epidermidis (1) }\end{array}$ \\
\hline & & & & Streptococcus viridans (3) \\
\hline & & & & $\begin{array}{c}\text { Streptococcus } \\
\text { pneumoniae (1) }\end{array}$ \\
\hline & & & & Enterococcus faecalis (1) \\
\hline & & & & Serratia marcescens (1) \\
\hline
\end{tabular}

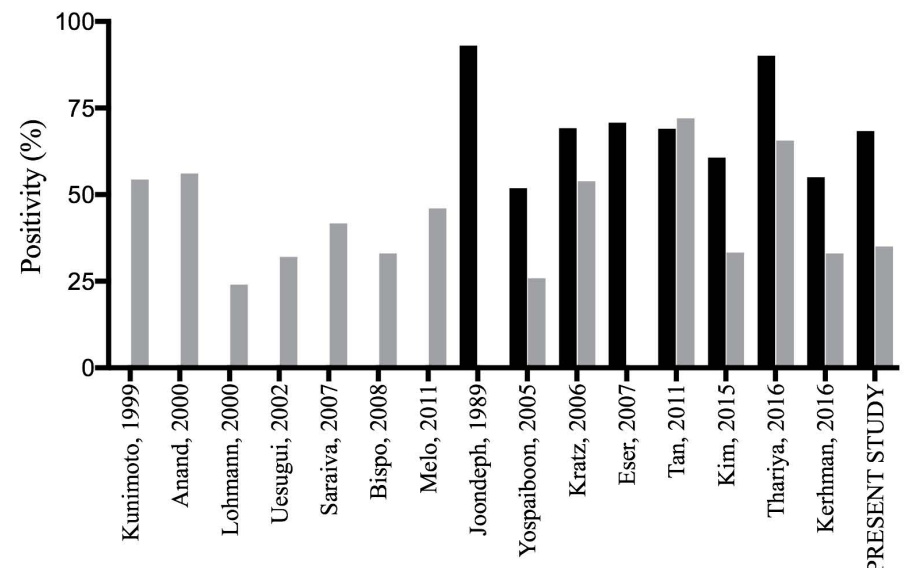

Figure 1 - Positivity (\%) of vitreous sample cultures of patients with endophthalmitis using the conventional method (gray) and pediatric blood culture bottles (black) in the medical literature and including the present study. 
are likely due to the limited volume of samples $(0.1-02 \mathrm{~mL})$ and previous use of antibiotic therapy (6). Similar to the present study, Kim et al. used PBCBs and CM at different times, reporting positivity of $60.7 \%$ and $33.3 \%$, respectively, across 50 samples $(8)$ Thariya et al. presented the largest cohort, with 342 patients, which showed $90.1 \%$ positivity in $\mathrm{BCBs}$ and $65.6 \%$ in $\mathrm{CM}(9)$. Only Tan et al. showed a different trend, i.e., a higher positivity with $\mathrm{CM}$ culture than with $\mathrm{BCBs}$, although the difference was not statistically significant (7).

In our institution. $\mathrm{PBCBs}$ had been used since 2012 for all intraocular samples from patients with endophthalmitis. The present study compared the positivity obtained with the conventional method (previous 2012) and with $\mathrm{PBCBs}$ and demonstrated a higher positivity with $\mathrm{PBCBs}(35 \%$ versus $64.7 \%$; $p=0.034$ ). These results are in agreement with previous studies and reinforce the advantages of using $\mathrm{PBCBs}$ as an alternative to $\mathrm{CM}$ for the etiologic dianosis of acute postoperative endophthalmitis $(3,6,9,10)$. Figure 1 summarizes the main studies using $\mathrm{CM}$ and $\mathrm{BCB} / \mathrm{PBCBs}$, including the present study.

The low number of samples for each method and the different periods of inclusion are the main limitations of the present study Additionally, although the use of $\mathrm{PBCBs}$ has several advantages over conventional culture, in cases where anaerobic pathogens are suspected, anaerobic BCBs or broth medium (e.g., thioglycolate broth) should be used (21). Nevertheless, these are the first case series of the advantages of $\mathrm{PBCBs}$ produced in Brazil and adding to the international literature The use of $\mathrm{PBCBs}$ should be recommended for microbiological diagnosis of endophthalmitis and is especially suitable for office settings and remote clinics.

\section{- CONCLUSION}

$\mathrm{PBCBs}$ confer a higher positivity than $\mathrm{CM}$ in cultures of vitreous samples of clinically suspected infectious endophthalmitis.

\section{- ACKNOWLEDGMENTS}

This study was financed in part by the Coordenação de Aperfeiçoamento de Pessoal de Nível Superior - Brasil (CAPES) Finance Code 001.

\section{- AUTHOR CONTRIBUTIONS}

Tanaka $\mathrm{T}$ helped to design the study, collected samples, collected microbiology data and drafted and reviewed the manuseript. Ferreira BFA, Kato JM and Oliveira LMS collected
samples and microbiology data. Gioia TSR, Rossi F, Pimentel SLG samples and microbiology data. Gioia TSR, Rossi F, Pimentel SLG
and Nakashima Y drafted and reviewed the manuscript. Yamamoto and Nakashima Y drafted and reviewed the manuscript. Yamamoto
JH and Almeida Junior JN helped to design the study, conducted the $\mathrm{JH}$ and Almeida Junior JN helped to design the study, conducted
statistical analysis, and drafted and reviewed the manuseript.

\section{- REFERENCES}

Jackson TL, Eykyn SJ, Graham EM, Stanford MR. Endogenous bacterial endophthalmitis: a 17-year prospective series and review of 267 reported $6257(03) 00054-7$

2. Taban M, Behrens A, Newcomb RL, Nobe MY, Saedi G, Sweet PM, et al. Acute endophthalmitis following cataract survery. a systematic review, ef a the literature. Arch Ophthalmol. 2005;123(5):613-20. https://doi. org/10.1001 archopht 123.5.613

3. Kratz A, Levy J, Belfair N, Weinstein O, Klemperer I, Lifshitz T. Broth culture yield v s traditional approach in the work-up of endophthalm itis. Am J Ophthalmol. 2006;141(6):1022-6. https://doi.org/10.1016/j.ajo.2006.01.076
Results of the Endophthalmitis Vitrectomy Study. Arandomized trial of immediate vitrectomy and of intravenous antibiotics for the treatment of postoperative bacterial endophthalmitis. Arch Ophthalmol. 1995; 113(12):1479-96. https://doi org/10.1001/archopht. 1995.01100120009001

5. Gan IM, Ugahary LC, van Dissel JT, Feron E, Peperkamp E, Veckeneer M, et 1. Intravitreal dexamethasone as adjuvant in the treatment of postoperative endophthalmitis: a prospective randomized trial Graefes Arch Clin Evp Ophthalmol. 2005:243(12) 1200-5, https://doi.org/10.1007/s00417-005-0133-1 Yospaiboon Y, Saree S, Pasadhika S. Blood culture and conventional media for vitreous culture in infectious endophthalmitis. J Med Assoc Thai 2005;88(5):639-42

7. Tan HS, Ghyczy-Carlborg EA, Spanjaard L, de Smet MD. The additional value of blood culture bottles in the diagnosis of endophthalmitis. Eye (Lond) 2011,25(8):1069-73. https://doi. org/10.1038/eye.2011.142

8. Kim KH, Kwon HJ, Park SW, Byon IS, Lee JE, Oum BS, et al. The effectiveness of pediatric blood culture bottle in endophthalmitis. I Korean Ophthalmol Soc 2015;56(9):1365-70. https://doi. org /10.3341/jkos.2015.56.9.1365

9. Thariya P, Yospaiboon Y, Sinawat S, Sanguansak T, Bhoomibunchoo C Laovirojianakul W. Blood culture bottles are superior to conventional media for vitreous culture. Clin Exp Ophthalmol. 2016;44(6):488-91. https://doi org $/ 10.1111 / \mathrm{ceo} .12707$

10. Chaib AR, Freitas D, Scarpi MJ, Guidugli T. [Laboratory findings in endophthalmitis] Arq Bras Oftalmol. 1997;60(3):250-7. https://doi.org/10.5935/0004-2749.19970056

1. Kunimoto DY, Das T, Sharma S, Jalali S, Maji AB, Gopinathan U, et al Microbiologic spectrum and susceptibility of isolates: part II. Posttraumatic endophthalmitis. Endophthalmitis Research Group. Am J Ophthalmol 1999, 128(2):242-4. htps://doi.org/10.1016/\$0002-9394(99)00113-0

12. Anand AR, Madhavan HN, Therese KL. Use of polymerase chain reaction (PCR) and DNA probe hybridization to determine the Gram reaction of the infecting bacterium in the intraocular fluids of patients with endophthalmitis. J Infect 2000;41(3):221-6. https://doi.org/10.1053/inf.2000.0731

13. Lohmann CP, Linde HJ, ReischlU. Improveddetection of microorganisms by polymerase chain reaction in delayed endophthalmitis after cataract surgery. Ophthalmology 2000;107(6):1047-51. https://doi.org/10.1016/S0161-6420(00)00083-X

14. Uesugui E, Cypel-Gomes MC, Atique D, Goulart DG, Gallucci FR, Nishiwaki-Dantas MC, et al. [Laboratory identification of the most frequen ocular pathogens and their in vitro sensitivity to antibiotics]. Arq Bras Oftalmol. 2002;65(3):339-42. https://doi.org/10.1590/S0004-27492002000300011

15. Saraiva FP, Costa PG, Inomata DL, Preti RC, Helal Jr J, Nakashima Y. Perfi clinico dos pacientes portadores de endoftalmite internados no Hospital das Clínicas de São Paulo. Rev Bras Oftalmol. 2007;66(3):169-74.

16. Melo GB, Bispo PJ, Regatieri CV, Yu MC, Pignatari AC, Höfling-Lima AL. Incidence of endophthalmitis after cataract surgery (2002-2008) at a Brazilian university-hospital. Arq Bras Oftalmol. 2010;73(6):505-7. https://doi.org/10.1590/S0004-27492010000600007

17. Bispo PJ, Höfling-Lima AL, Pignatari AC. Molecular biology applied to the laboratory diagnosis of bacterial endophthalmitis. Arg Bras Oftalmol 2009;72(5):734-40. https://doi.org/10. 1590/S0004-27492009000500028

18. Church DL, Davies HD, Cadrain G, Trevenen CL. Comparative study of three different BACTEC culture media for the detection of bacteremia in ambulatory and hospitalized children. Can I Infect Dis. 1998;9(2):77-82 hittps://doi.org/10.1155/1998/603898

19. Joondeph BC, Flynn HW Jr, Miller D, Joondeph HC. A new culture method for infectious endophthalmitis. Arch Ophthalmol. 1989;107(9):1334-7 https:/doi.org/10.100/archopht.1989.01070020404044

20. Eser I, Kapran Z, Altan T, Eren H, Yilmaz OF. The use of blood culture bottles in endophthalmitis. Retina. 2007,27(7):971-3. https://doi. org/10.1097 IAE.0b0 $13 \mathrm{e} 31802 \mathrm{bfe} 0$

21. Rachitskaya AV, Flynn HW Jr, Wong J, Kuriyan AE, Miller D. A 10-year study of membrane filter system versus blood culture bottles in culturing vitrectomy cassette vitreous in infectious endophthalmitis. Am J Ophthalmol 2013;156(2):349-354.e2. https://doi.org/10.1016/j.ajo.2013.03.040

22. Kehrmann J, Chapot V, Buer J, Rating P, Bornfeld N, Steinmann J Diagnostic performance of blood culture bottles for vitreous culture compared to conventional microbiological cultures in patients with suspected endophthalmitis. Eur J Clin Microbiol Infect Dis. 2018;37(5):889-95. https:/ doi.org/10.1007/s10096-017-3182-6

23. Chiquet C, Maurin M, Thuret G, Benito Y, Cornut PL, Creuzot-Garcher C, et al Analysis of diluted vitreous samples from vitrectomy is useful in eyes with severe acute postoperative endophthalmitis. Ophthalmology. 2009;116(12):2437-41.el https://doi.org/10.1016/j.ophtha.2009.06.007 